



\section{GOVERNANCE AND \\ INSTITUTIONAL RISKS \\ AND CHALLENGES IN NEPAL}

Rachana Shrestha

DECEMBER 2019 
(C) 2019 Asian Development Bank 6 ADB Avenue, Mandaluyong City, 1550 Metro Manila, Philippines

Tel +632 8632 4444; Fax +63286362444

www.adb.org

Some rights reserved. Published in 2019.

ISBN 978-92-9261-834-6 (print), 978-92-9261-835-3 (electronic)

Publication Stock No. TCS190551

DOI: http://dx.doi.org/10.22617/TCS190551

The views expressed in this publication are those of the authors and do not necessarily reflect the views and policies of the Asian Development Bank (ADB) or its Board of Governors or the governments they represent.

ADB does not guarantee the accuracy of the data included in this publication and accepts no responsibility for any consequence of their use. The mention of specific companies or products of manufacturers does not imply that they are endorsed or recommended by ADB in preference to others of a similar nature that are not mentioned.

By making any designation of or reference to a particular territory or geographic area, or by using the term "country" in this document, $A D B$ does not intend to make any judgments as to the legal or other status of any territory or area.

This work is available under the Creative Commons Attribution 3.0 IGO license (CC BY 3.0 IGO)

https://creativecommons.org/licenses/by/3.o/igo/. By using the content of this publication, you agree to be bound by the terms of this license. For attribution, translations, adaptations, and permissions, please read the provisions and terms of use at https://www.adb.org/terms-use\#openaccess.

This CC license does not apply to non-ADB copyright materials in this publication. If the material is attributed to another source, please contact the copyright owner or publisher of that source for permission to reproduce it. $\mathrm{ADB}$ cannot be held liable for any claims that arise as a result of your use of the material.

Please contact pubsmarketing@adb.org if you have questions or comments with respect to content, or if you wish to obtain copyright permission for your intended use that does not fall within these terms, or for permission to use the ADB logo.

Corrigenda to ADB publications may be found at http://www.adb.org/publications/corrigenda.

Note:

In this publication, “\$” refers to United States dollars.

Cover design by Francis Manio. 


\section{Contents}

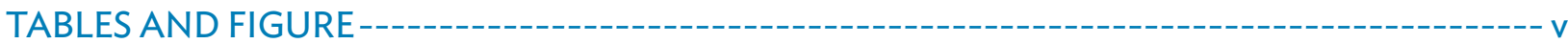

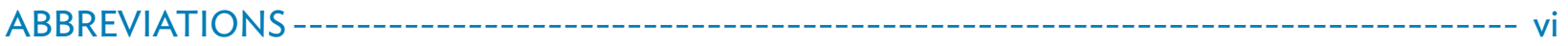

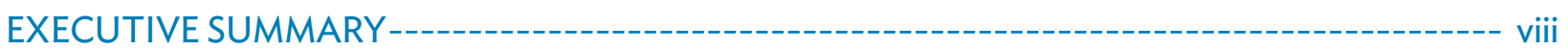

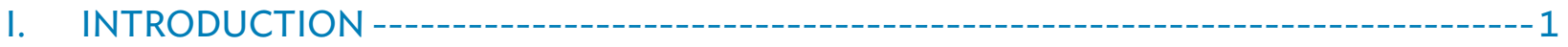

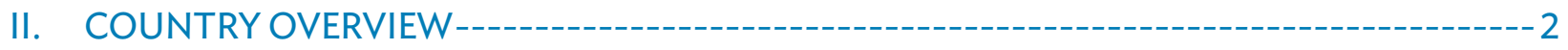

A. Historical, Political, and Economic Context............................................................................................. 2

B. Governance and Institutional Arrangements .......................................................................................... 4

C. Country Development Strategies .....................................................................................................................

III. ASSESSMENT OF COUNTRY SYSTEMS-------------------------------------------------10

A. Institutional Arrangements in the Federal Structure .........................................................................10

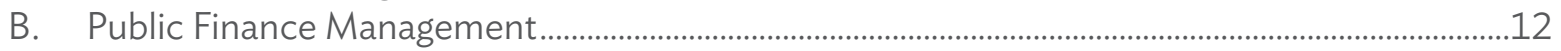

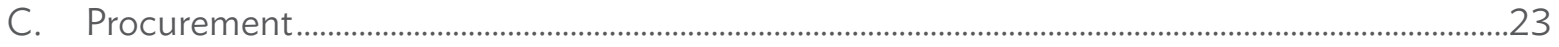

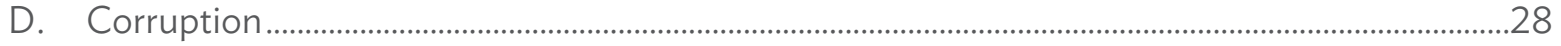

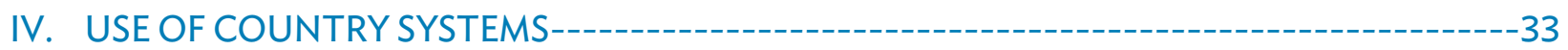

V. GOVERNANCE AND INSTITUTIONAL CHALLENGES AND RISKS IN SECTORS -----------36

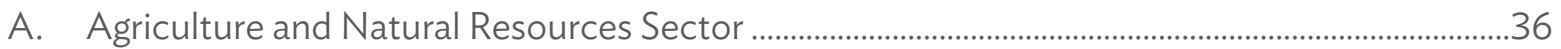

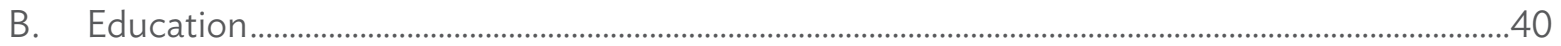

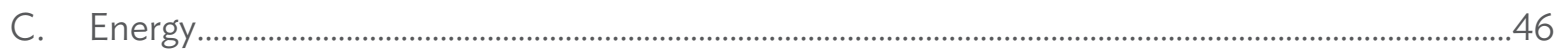

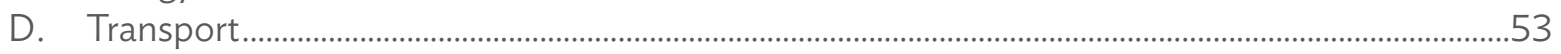

E. Water and Other Urban Infrastructure and Services Sector .............................................................58

\section{APPENDIXES}

$1 \quad$ List of Persons Met During the Consultation Meetings......................................................................65

2 Overview of Country Governance Surveys ..........................................................................................69

3 Donor Mapping Federalization Support ....................................................................................................81 
4 ADB Sectors, Subsectors, and Government of Nepal Alignments with Ministries Allocated with Specific Business Covering Those Sectors and Subsectors as per the Government of Nepal Business Rules...

5 Summary of Rights and Responsibilities of Various Levels of Government..

6 Scope of Local Government Responsibilities and ADB Sectors and Subsectors ........................98

7 ADB Sectors and Assigned Government Ministries in Provinces ......................................................99

8 Summary of Public Expenditure and Financial Accountability Secretariat 2015 Assessment in Nepal.

9 Summary of Subnational Public Expenditure and Financial Accountability Secretariat 2015 Findings 


\section{Tables and Figure}

\section{TABLES}

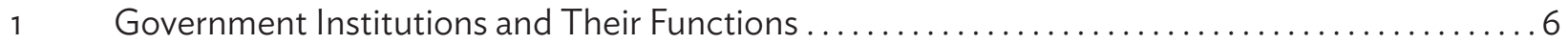

2 Summary of Public Expenditure and Financial Accountability Ratings in 2008 and $2015 \ldots \ldots 13$

3 Public Finance Management Legal Framework ...................................... 14

4 Donor-Funded Reform Programs and Projects in PFM . . . . . . . . . . . . . . . . . . . . . . 20

5 Summary of Country/Sector Procurement Assessment, Nepal (2016) .................... 25

$6 \quad$ Nepal PEFA Ratings for Public Procurement. . . . . . . . . . . . . . . . . . . . . . . . . . 25

$7 \quad$ Worldwide Governance Indicators, $\operatorname{Nepal}(2006,2011$, and 2016) .......................

$8 \quad$ ADB Nepal Portfolio (Sector Loans and Grants)................................... 33

9 Responsible Ministries (Federal) for Agriculture and Natural Resources Subsectors . . . . . . . . . 37

10 Functional Assignments Under Federal Context in the Education Sector..................40

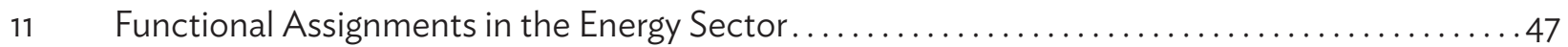

12 Energy Sector Budget versus Expenditure Capital. ................................ 49

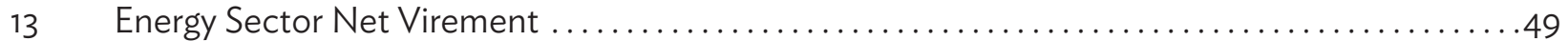

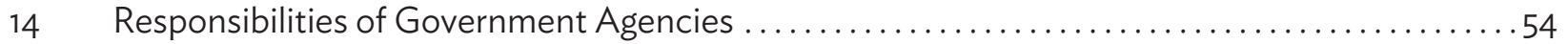

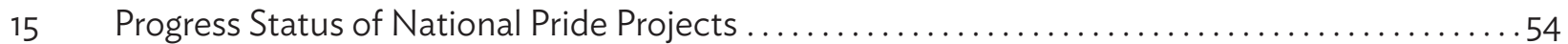

16 Institutional Framework in Urban and Water Sector in the Federal Context ................59

A2.1 The Economist Intelligence Unit's Index of Democracy . . . . . . . . . . . . . . . . . . . .70

A2.2 Transparency International Corruption Perception Index ........................ 71

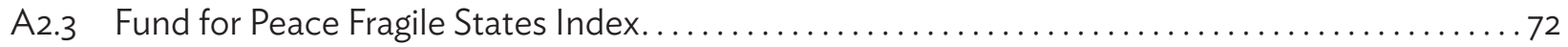

A2.4 The Heritage Foundation Index of Economic Freedom $\ldots \ldots \ldots \ldots \ldots \ldots \ldots \ldots \ldots \ldots \ldots \ldots \ldots$

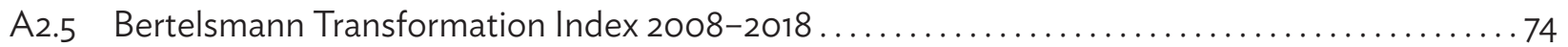

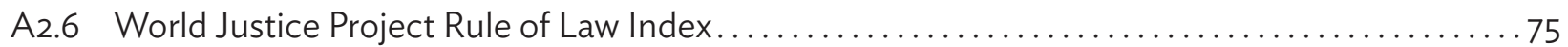

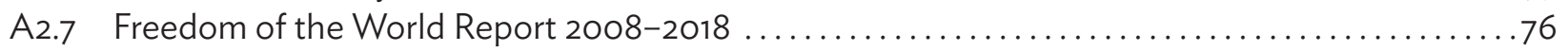

A2.8 Reporters Without Borders World Press Freedom Index ........................... 77

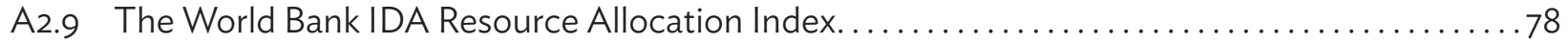

A2.10 ADB Country Performance Assessment. ........................................ 79

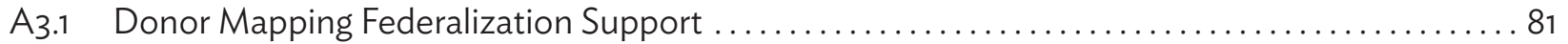

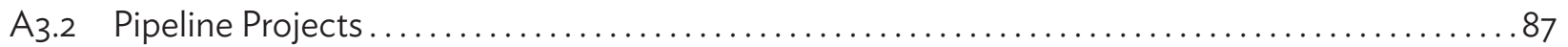

A9.1 Portfolio of ADB Projects in Nepal . . .............................................. 105

A9.2 ADB Nepal Resident Mission-Total Loans and Grants in Sectors . . . . . . . . . . . . . . . . . 107

A9.3 ADB Nepal Resident Mission — List of Active TAs by Sector ............................. 108

\section{FIGURE}

World Bank Institute WGIs ............................................69 


\section{Abbreviations}

$\begin{array}{ll}\text { ADB } & \text { Asian Development Bank } \\ \text { ANR } & \text { agriculture and natural resources } \\ \text { BTI } & \text { Bertelsmann Stiftung's Transformation Index } \\ \text { CSPAR } & \text { Country/Sector Procurement Assessment Report } \\ \text { CIAA } & \text { Commission for Investigation of Abuse of Authority } \\ \text { CPI } & \text { Corruption Perception Index } \\ \text { DCC } & \text { District Coordination Committee } \\ \text { DDC } & \text { District Development Committee } \\ \text { DFID } & \text { Department for International Development (United Kingdom) } \\ \text { DTCO } & \text { District Treasury Controller Office } \\ \text { e-GP } & \text { electronic government procurement } \\ \text { EIU } & \text { Economist Intelligence Unit } \\ \text { FCAN } & \text { Federation of Contractors Association of Nepal } \\ \text { FCGO } & \text { Financial Controller General's Office } \\ \text { GDP } & \text { gross domestic product } \\ \text { ICT } & \text { information and communication technology } \\ \text { IDA } & \text { International Development Association } \\ \text { KUKL } & \text { Kathmandu Upatyaka Khanepani Limited } \\ \text { MOALD } & \text { Ministry of Agriculture and Livestock Development } \\ \text { MOEWRI } & \text { Ministry of Energy, Water Resources and Irrigation } \\ \text { MOEST } & \text { Ministry of Education and Science and Technology } \\ \text { MOF } & \text { Ministry of Finance } \\ \text { MOFAGA } & \text { Ministry of Federal Affairs and General Administration } \\ \text { MOFALD } & \text { Ministry of Federal Affairs and Local Development } \\ \text { MOPIT } & \text { Ministry of Physical Infrastructure and Transport } \\ \text { MOUD } & \text { Ministry of Urban Development } \\ \text { NEA } & \text { Nepal Electricity Authority } \\ \text { NPC } & \text { National Planning Commission } \\ \text { NVC } & \text { National Vigilance Centre } \\ \text { OAG } & \text { Office of Auditor General } \\ \text { OPMCM } & \text { Office of the Prime Minister and Council of Ministers } \\ \text { PEFA } & \text { Public Expenditure and Financial Accountability Secretariat } \\ \text { PFM } & \text { public financial management } \\ \text { PFMRP } & \text { public financial management reforms plan } \\ \text { PID } & \text { Project and Program Implementation Directorate } \\ & \end{array}$


PPA Public Procurement Act

PPMO Public Procurement Management Office

PPR public procurement regulation

SDG Sustainable Development Goal

SNG

SPMP subnational government

WSMB Strengthening Public Management Program Water Supply Management Board

\section{CURRENCY EQUIVALENT}

as of 19 February 2019

\section{Currency Unit - Nepalese Rupee \\ $\mathrm{NRe} 1.00=\$ 0.0087$ \\ $\$ 1.00=N R s 115.00$}

The fiscal year (FY) of the Government of Nepal and its agencies ends in mid-July. FY before a calendar year denotes the year in which the fiscal year ends, for example, FY 2019 ends on 16 July 2019. 


\section{Executive Summary}

T his report was written to inform the preparation of the country partnership strategy of the Asian Development Bank in Nepal for 2020-2024.

Political and economic context. Nepal has been through tumultuous political changes in the last 3 decades, including a decade-long armed struggle (1996-2006) and 7 constitutions in the last 70 years. On 20 September 2015, the newly adopted constitution transformed Nepal into a federal democratic republic with three government tiers: central (federal), provincial ( $x 7)$ and local (x753). Each tier has legislative, executive, and judicial functions and authority under exclusive and shared jurisdictions. Governments in all three tiers were formed in early 2018 following elections in 2017.

Gross domestic product. Nepal's gross domestic product (GDP) growth averaged $4.3 \%$ over the past decade. The fiscal deficit has widened from an average of $1.2 \%$ of GDP in the past decade to 3.2\% in FY2017 and 6.7\% in FY2018. Inflation has also been stubbornly high, averaging $9 \%$ in the last decade largely due to supply-side constraints, including anticompetitive practices, as noted in ADB's Nepal Macroeconomic Update and the Nepal Budget 2019 Analysis.

Policies, strategies, and planning. The Constitution of Nepal provides the legal framework and basis for policy formulation. There is a formal procedure in preparing and endorsing legal acts following an extensive discussion in Parliament. Necessary policies, regulations, and guidelines are then developed by sector ministries in line with the relevant acts. Laws and regulations are not changed arbitrarily and are publicly available in Nepal.

The National Planning Commission (NPC), Ministry of Finance (MOF), and sector ministries are responsible for development planning and budgeting. The government's development strategy is outlined in the most recent development plan, the Fourteenth Three-Year Plan (FY2017- FY2019), which is currently under implementation. It aims to achieve socioeconomic transformation and reduce poverty through high economic growth, productive employment, and fair distribution.

Institutional arrangements in the federal structure. The transition from a unitary to a federal system of governance remains challenging with several laws yet to be formulated and enacted, institutional arrangements at all government levels yet to be finalized, and policies and guidelines yet to be prepared. Substantial overlaps, duplications, and ambiguities among government tiers remain.

Most sector ministries and departments at the federal level have been downsized or restructured as several functions have been devolved to subnational governments (SNGs). Executing and implementing agencies of several ADB funded projects have been changed, and regional and district offices previously under federal sector ministries have been closed. This has disrupted service delivery as the provincial governments are only newly established and local governments do not have adequate institutional capacity 
to undertake all the assigned functions. The functioning of the SNGs has also been affected by the lack of human resources and low capacity of several staff members.

Public institutions. Institutional development and strengthening of public institutions, particularly at the SNG level, is one of the key reform priorities for the efficient implementation of federalism, and where ADB could provide policy advisory and technical support through its programs and projects. It will be important to assess the agencies that are executing and implementing projects. The implementation modalities of ongoing projects may need to be adjusted, and pipeline projects may need to include institutional strengthening plans.

Public financial management (PFM). The Public Expenditure and Financial Accountability Secretariat reported in 2015 that out of 28 performance indicators, 16 improved, 10 remained unchanged, and two deteriorated, which shows an overall improvement in PFM. Nonetheless, there are several PFM-related challenges and risks, including:

(a) Fiscal indiscipline: While there are financial laws and regulations to instill fiscal discipline, they are not fully complied with and are poorly enforced. The annual reports of the Office of the Auditor General (OAG) in the last few fiscal years have reported widespread financial irregularities and indiscipline, such as high variances (up to 21 times) and "bunching" of capital expenditure (70\%) at the end of the fiscal year, which increases the risk of poor service delivery, financial mismanagement, and poor quality infrastructure.

(b) Disconnect between planning and budgeting: An analysis of the federal budget data of the past 5 years shows poor prioritization of projects and programs leading to spending in nonprioritized areas. Also, several projects are listed under priority projects and are considered more on political grounds than on strategic importance.

(c) High fiduciary and corruption risks: Nondigitization of financial functions, an inadequate number of PFM experts, weak technical capacity of accountants, poor internal control, and weak enforcement of corrective measures against flagged irregularities and recommendations of OAG are additional challenges that have increased fiduciary and corruption risks, particularly in SNGs.

(d) Implementation of fiscal federalism in SNGs: This is a challenge given the poor institutional capacity, weak PFM system, inadequate human and financial resources, and insufficient knowledge and experience. While the huge dependency of SNGs on central transfers can be reduced by increasing domestic resources and revenue mobilization (DRM), this is possible only after putting in place the appropriate institutional mechanisms, policies, and capacity development, which are yet to be initiated.

SNG support. Given the substantial number of PFM challenges in SNGs, it is recommended that ADB's support in PFM be at the SNG level. Improved PFM systems in SNGs will support ADB's operations, mainly agriculture and natural resources (ANR), education, and urban and water sectors as most programs and projects in these sectors are implemented by SNGs under the federal structure. ADB should consider a PFM-focused program as a critical area of engagement. Some of the other reform areas that would address the risks are listed below. These areas could be supported through 
ADB's investment projects and programs, technical assistance, knowledge solutions, and policy dialogues.

(a) Conduct an assessment of institutional arrangements for PFM at all government levels and potential risks for ongoing and pipeline projects. This will provide information on the implementation of the federal system and any specific reform measures that $A D B$ should be taking within the portfolio or in program and project design to facilitate implementation of the federal system or mitigation of PFM risks.

(b) Establish a program and project bank, a database of projects and programs, including sector categorization and prioritization of the projects based on objectively defined criteria and project readiness, followed by preparation of realistic procurement plans, and linking multi-year budgeting with the project bank.

(c) Strengthen internal control and internal audit in line with the Public Expenditure and Financial Accountability Secretariat (PEFA) national and subnational recommendations of 2015 and as guided by ADB supported policy advisory technical assistance on strengthening subnational public management in Nepal.

(d) Digitalize the PFM system, including the information management, and asset management systems. This will require robust implementation strategies. A capacity development plan should be a part of the reform plan.

(e) Prepare a well-functioning fiscal federalism framework with equitable distribution of resources and clear functional assignments. Since increased DRM will make SNGs more independent, accountable, and capable of delivering increased and better public services, it should be prioritized and supported.

Procurement. The Public Procurement Act (PPA), 2007 and Public Procurement Regulation (PPR), 2007 form the legal framework for procurement in Nepal and are based on international standards. The PPA is applicable to all public procurements with open competitive bidding as the default method of public procurement. The Public Procurement Management Office (PPMO) has developed and rolled out a web-based electronic government procurement (e-GP) system.

The country and sector procurement assessment report was prepared in 2016 to identify country and sector level issues that hinder procurement processes and suggest mitigation measures. The Country/Sector Procurement Assessment Report (CSPAR) was updated in July 2018. Based on the CSPAR 2016 and the 2018 update, Nepal's procurement risk is rated "Substantial" (national level), and for sectors from "Substantial to Moderate" (on a scale of "High," "Substantial," "Moderate" and "Low"). Based on PEFA 2015, the overall assessment on procurement related dimension ( $\mathrm{PI}-19$ ) is $B$ on of a scale of $A, B, C, D$ with $A$ being the best.

Some major challenges and risks in procurement include:

(a) The PPMO has weak institutional capacity, including inadequate human resources and procurement experts, absence of procurement databases and information management systems, and poor implementation and enforcement of laws and regulations.

(b) Weak contract management of procuring entities causes time and cost overruns in projects. According to the PPMO annual report 2017, not a single infrastructure project in Nepal has been 
completed on time and one of the major causes has been weak contract management.

(c) There is a mismatch between contract size and capacity of local contractors. By bidding beyond capacity, contractors fail to complete projects on time.

(d) Situations of joint ventures with ghost consultants and contractors lead to delays and poor quality outputs.

(e) Situations of abnormally low bid prices lead to delays, nonperformance, and low-quality products.

(f) Unwarranted slicing of procurement packages to dissuade competition is against the procurement law.

(g) There is collusion between bidders and procuring entities. It is estimated that about $51 \%$ of firms in Nepal give gifts to secure government contracts, which is more than twice the regional average.

(h) Technical problems in operating the e-GP system lead to use of the old system and increased procurement risks.

Making the e-GP system (developed under the ADB-financed Strengthening Public Management Program) fully functional with adequate technical backstopping support is a reform priority which ADB should consider supporting. This will reduce procurement related risks, such as collusion and intimidation, and increase efficiency and transparency.

Given the critical importance of PPMO in monitoring and regulating public procurement, institutional strengthening of PPMO is key to addressing procurement risks, including mechanisms to detect and deter collusive practices among bidders and procuring entities.
Corruption. Nepal is ranked 124 out of 180 countries, with a score of 31 (100 is the least corrupt) in the Transparency International Corruption Perception Index 2018. This indicates that corruption is endemic in Nepal. The Commission for Investigation of Abuse of Authority (CIAA) is the apex constitutional body that investigates corruption by public officials. Despite having a sound legal framework and political party leaders and government authorities routinely speaking out against corruption, eliminating corruption in Nepal remains an elusive goal. Some of the major challenges in combating corruption include:

(a) poor implementation and enforcement of rules and regulations

(b) weak institutional capacity of oversight institutions

(c) increasing impunity due to negligible departmental and legal actions against those guilty of corruption and several corruption cases remaining uncovered or unpunished

(d) increased costs of doing business in Nepal (bribery in the form of "facilitation payments" is widespread in the distribution of permits and approvals, public procurement, contract awards, and when registering a business)

ADB support should focus on strengthening PFM and procurement systems to address corruption risks.

Use of country systems. ADB generally uses country systems in Nepal for the administration of loans and grants but for TA projects, ADB follows its own system for procurement and financial management. ADB's assistance to Nepal in the form of loans and grants is fully "on-budget," whereas the TA projects are "off-budget." 
ADB's loans and grants proceeds are reflected in the government's treasury system but they are transferred to special accounts under the government's consolidated fund and managed as agreed between ADB and the government, and in accordance with ADB's Loan and Disbursement Handbook, so the system is partially used. Regarding ADB's project accounting, $A D B$ requires implementing agencies to maintain separate project accounts and records for ADBfunded projects and their financial statements are audited by the Office of Auditor General (OAG).

ADB uses country systems for national competitive bidding for procurement of goods and services under specified thresholds. For procurement above specified thresholds, an international competitive bidding process as per ADB's guidelines is used.

There are systemic issues that need to be addressed before further advancements in the use of country systems in PFM can be made. These include incomplete digitization of the PFM system that is integrated with other data management systems, and low institutional capacity of SNGs. The PFM system is not yet fully established, digitized, or functional in these governments. Strategic interventions through policy reforms and technical assistance need to be provided to federal and SNGs to improve the overall PFM system. Only then can ADB anticipate fully using the country system in PFM.

Full use of the country system in procurement requires significant reforms, including

(a) institutional strengthening of the Public Procurement Monitoring Office (PPMO),

(b) upgrading and operationalizing the e-GP system with provisions for adequate technical support, (c) revision of Nepal's Public Procurement Act to make public procurement more competitive and include international policies and practices, and

(d) strengthening of oversight agencies.

Until these reforms are undertaken, ADB should continue the current approach of using the country system for national competitive bidding and ADB's system for international competitive bidding.

Governance risks and challenges within sectors. A summary of the specific risks and challenges in sectors where ADB Nepal has operations is provided below.

(a) Agriculture and Natural Resources: The policy environment in this sector, particularly in the agriculture subsector, is weak. For example, in the absence of an agriculture act, contract farming, leasing, public-private partnerships, and access to agricultural finance are lacking. The sector also suffers from weak institutional capacity, which has negatively affected planning, budgeting, project design and implementation, undertaking procurement processes, contract management, and financial management. Poor links between budget and sector plans, ineffective financial management, and weak spending capacity of implementing agencies are other PFM challenges in the sector. Weak compliance with rules and regulations, and poor contract management are also procurement challenges. According to CIAA and OAG, ANR receives the highest number of complaints on substandard quality of works and misuse of public funds. Institutional assessment of ongoing 
and new projects is recommended to make appropriate institutional arrangements under the federal context and to identify areas that need to be strengthened, particularly at the SNG level.

(b) Education: Although the federal constitution of Nepal has functionally assigned education responsibilities to all three levels of government, school sector duties are mostly assigned to local governments. Due to the poor institutional and technical capacity of local governments and in the absence of a clear demarcation of roles, responsibilities, and coordination mechanisms among the government tiers, the risk of poor service delivery in education has further increased. Inadequate allocation of financial resources, fiscal indiscipline, and inefficient expenditures leading to poor service delivery and high fiduciary risks are the major PFM risks in this sector. In terms of procurement, poor capacity for procurement functions, particularly at the SNG level, is a significant challenge which will increase the risk of implementation delays, noncompliance with procurement regulations, and weak contract management. The CIAA annual report 2017 recorded the largest number of corruption cases in the education sector. The OAG 2018 report also observed that scholarship funds are misappropriated and poorly monitored, and performance of schools, resource centers and district education offices are weak. Recommended policy measures to address the risks in this sector are

(i) institutional rearrangements to suit the federal context; (ii) institutional assessments and strengthening plans for local governments, including a PFM reform plan; and

(iii) preparation of procurement guidelines specific to the sector.

(c) Energy: In accordance with the federal structure of governance, provincial governments are given authority in this sector but are yet to establish or reorganize their agencies to execute their functions. Moreover, the Local Government Operations Act, 2017 includes mandates for local governments for small hydropower projects and alternative energy but most do not have the required institutional arrangements, capacities, or human resources to execute their functions. Although the performance of the electricity subsector has improved in the last few years, the sustainability of these achievements will depend on reform actions to effectively address some of the key institutional challenges and constraints in the sector. These include

(i) poor inter-ministerial coordination resulting in delays in decisionmaking,

(ii) weak institutional and technical capacity of government agencies and Nepal Electricity Authority, and

(iii) ineffective project management and internal control systems.

The OAG 2018 annual report highlighted high financial indiscipline and noncompliance, and poor implementation of the Nepal Electricity Authority Financial Restructuring Plan. ADB's CSPAR 2016 and 2018 update for 
Nepal specify that the energy sector has substantial risks in procurement. The CIAA 2018 report highlighted violations of the Electricity Act in furnishing survey licenses and amendments to those licenses. Institutional rearrangements as appropriate for ongoing projects and institutional strengthening plans for new ones are recommended.

(d) Transport: Almost all the projects in this sector suffer huge time and cost overruns, including national pride projects. Weak institutional capacity of executing and implementing agencies has been one of the main causes for implementation delays. Poor resource planning and management, fiscal indiscipline (e.g., nearly $70 \%$ of the total expenditures are undertaken during the last trimester of the fiscal year), noncompliance, and poor accountability have given rise to fiduciary risks, and compromised the quality of infrastructure projects. Transport is a high-spending sector with an annual budget of over $2 \%$ of the GDP. The CSPAR 2016 and 2018 update show that procurement risks associated with this sector are substantial in two pillars: (i) procurement operations and market practices and (ii) integrity and transparency of the public procurement system. Transport procurement risks are moderate in two other pillars: (i) legislative and regulatory frameworks, and (ii) institutional framework and management capacity.

The 2018 CIAA report indicated misappropriation of funds, inaction against those guilty, and cases of forgery in the sector. Institutional assessment in the federal context and strengthening, including fully automated PFM and procurement systems are recommended to address these governance risks. (e) Urban and Water: Local governments are the main implementing agencies of sector programs and projects. Weak institutional capacity of local governments is a major challenge in delivering efficient services.

Appropriate systems and processes for administrative, financial, and project management are yet to be put in place in many local governments. Poor planning and lack of prioritization is prevalent in the sector. For example, before the completion of ongoing projects, new projects get added every year. Out of 5,037 drinking water projects implemented in FY2017, 2,693 were ongoing projects while 2,344 were new. The PFM systems in most local governments are not fully digitized. Financial reporting by local governments is also scanty, not comprehensive, and accounts are not reconciled. Fiduciary risks in many local governments therefore remain high. Procurement capacity, contract management, and technical knowledge is poor. Most projects are not completed within the stipulated time. Contract periods are repeatedly extended creating substantial financial burdens. Corrupt practices in user committees such as the involvement of fake beneficiaries and/or committee members have been reported by CIAA and $\mathrm{OAG}$. Also, collusive practices among local government authorities, political parties, and user committees were reported but hardly any actions are taken. Institutional assessment under the federal context and strengthening, including fully automated PFM and procurement systems are recommended to address these governance risks. 


\section{INTRODUCTION}

$\mathrm{T}$ his report aims to inform the preparation of the country partnership strategy for the Asian Development Bank (ADB) in Nepal for 2020-2023. It assesses governance issues and changed institutional arrangements under the new federal context that could have implications for ADB's operations and recommended reform measures to address those risks. This country-level assessment follows ADB's Second Governance and AntiCorruption Plan framework and guidelines for the assessment of governance risks, public financial management (PFM), procurement, and combating corruption. ${ }^{1}$ It also analyzes these risks in the context of the federal system of governance that Nepal adopted in September 2015 following the promulgation of the new constitution. The analysis also includes institutional arrangements and challenges in the federal context. While the assessment is mainly focused at the federal and national level, some of the major challenges at the subnational level in the federal context are also discussed. It should be noted that institutional arrangements, functional assignments and authority, and modalities of development operations among the three government tiers (federal, provincial, and local) are yet to be fully clarified. New challenges and risks could hence emerge during the process, which would need to be analyzed separately during the implementation of the new country partnership strategy.

The analysis draws on studies and extensive discussions with stakeholders (ADB, government, elected officials, private sector, and development partners) at federal, provincial, and local government levels. The bibliography provides a list of publications reviewed in preparing this report.

The report includes a country overview, and an assessment of systems. The recommendations on reform measures to be incorporated in ADB operations in Nepal seek to address operational challenges in the federal system of governance, use of country systems, and governance risks and challenges in sectors where ADB has operations, namely agriculture and natural resources, education, energy, transport, and water and other urban infrastructure and service sectors.

The assessment team is grateful to the sector and thematic leads in ADB, officials of the Government of Nepal, elected representatives, and development partners. See Appendix 1 for a list of the people consulted and the organizations they represent.

1 ADB. 2006. Second Governance and Anticorruption Action Plan (GACAP II). Manila. 


\section{COUNTRY OVERVIEW}

\section{A. Historical, Political, and Economic Context}

Nepal has been through tumultuous political changes in the last 3 decades, including a decade-long armed struggle and 7 constitutions in the last 70 years. Nepal completed its complex and protracted political transition to democracy with the peace accord signed in April 2006, leading to the promulgation of an interim constitution in 2007 . The newly formed Constituent Assembly in 2008 declared Nepal a federal democratic republic, abolished the monarchy, and elected the country's first president. The political reconciliation during 2012-2015 was uneasy, with the dissolution of the Constituent Assembly in May 2012 without finalizing the new constitution and frequent changes of government due to the fragmented political landscape. A second Constituent Assembly was then formed in November 2013.

On 20 September 2015, a new constitution was adopted, which transformed Nepal into a federal democratic republic. The salient features of the Constitution include

- a federal government: central (1), provincial (7), local (753 urban and rural municipalities), and district coordination committees; ${ }^{2}$
- a proportional and inclusive system of governance;

- a secular, socialist-oriented democratic republic;

- a focus on inclusive economic growth with regional balance and peoples' participation in local development activities;

- sustainable use of natural resources with equitable distribution of benefits; and

- priority rights for local people. $^{3}$

The elections of the three government tiers were conducted in 2017 and governments were formed by early 2018. The new federal government formed by the Nepal Communist Party commands a comfortable majority in the federal Parliament and with the support of the Federal Socialist Party (the fourth largest party in the Parliament), they have secured a two-thirds majority. ${ }^{4}$ The ruling Nepal Communist Party also formed six out of seven provincial governments. Of the 753 local governments, more than 400 are run by Nepal Communist Party mayors. ${ }^{5}$ The new government after the 2017 elections has brought a sense of political stability in the country.

The transition from a unitary to a federal system of governance remains challenging although the government has initiated and achieved

2 The former 75 district development committees, one metropolitan city, 12 sub-metropolitan cities, 204 municipalities and 3,157 village development committees were restructured into 753 local governments (4 metropolitan cities, 13 sub-metropolitan cities, 255 urban municipalities and 481 rural municipalities).

3 Nepal Law Commission. 2015. Constitution of Nepal, 2015. Kathmandu.

4 The Communist Party of Nepal (Unified Marxist-Leninist) and Maoist Center earlier participated in national elections as a coalition and merged later into the Nepal Communist Party.

5 As reported on the websites of the Ministry of Federal Affairs and General Administration (www.mofaga.gov.np) and Election Commission (www.election.gov.np). 
several milestones, including restructuring of local governments through a constitutional commission, restructuring of existing public institutions at different levels, and formulation and approval of new laws, and amendment of existing laws. Nonetheless, the transition process remains daunting with several laws yet to be formulated and enacted, institutional arrangements at all government levels yet to be finalized, and policies and guidelines yet to be prepared. Furthermore, the 2015 constitution has assigned legislative, executive, and judicial functions to all government tiers under exclusive and shared jurisdictions. Although the functional analysis and assignment report attempted to unbundle concurrent functions among the government tiers, substantial overlaps, duplications, and ambiguities remain. ${ }^{6}$ There are also provisions for intergovernmental fiscal transfers and revenue sharing to compensate for vertical fiscal imbalances and offset horizontal disparities, but the design and implementation of a well-functioning fiscal federal framework is yet to be accomplished.

Nepal's GDP growth averaged 4.3\% over the past decade (FY2009-2018). ${ }^{7}$ Growth slowed sharply to $0.2 \%$ in FY2016 from a high of 5.7\% in FY2014, reflecting the loss of income and productive capacity due to the earthquakes in 2015, delays in post-earthquake reconstruction, unrest in the Terai region leading to trade and supply disruptions between September 2015 and
February 2016, and an unfavorable monsoon. Growth in FY2017 was 7.4\% with the increase of post-earthquake reconstruction works, the normalization of trade and supply, and a favorable monsoon. Nepal's economy is anticipated to grow at a slower pace of around 5.9\% in FY2018. ${ }^{8}$ The growth process has been largely inclusive, with a significant reduction in the national poverty rate from $30.9 \%$ in 2004 to $25.2 \%$ in 2011. ${ }^{9}$ Inequality also fell, with the Gini Index falling from 43.3 to 32.8 in the same period. The growing inflow of remittances has been one of the main contributors to poverty reduction and inclusive growth. ${ }^{10}$ Nevertheless, the country still faces wide socioeconomic disparities between geographic regions and ethnic and social groups. ${ }^{11}$ The government recognizes this and is strategizing to graduate from the least developed country category by 2022 and become a middleincome country while achieving the Sustainable Development Goals by 2030.

Nepal's fiscal deficit has widened from an average of $1.2 \%$ of GDP in the past decade to $3.2 \%$ in FY2017, underpinned by increased government expenditures. Rising recurrent and poor execution of capital expenditures are a concern. Recurrent expenditures rose rapidly from $12.7 \%$ of GDP in FY2010 to 23.2\% of GDP in FY2018, partly reflecting fiscal transfers to subnational governments (SNGs) under the federal structure of government that came into effect in 2017. With expenditures falling short of budget allocations,

6 Government of Nepal. 2015. Functional Analysis and Assignment of Government. http://www.np.undp.org/content/ $\mathrm{dam} / \mathrm{nepal} / \mathrm{docs} /$ generic/FunctionalAnalysisandAssignment.pdf.

7 At basic prices. The fiscal year (FY) of the Government of Nepal ends in mid-July. FY before a calendar year denotes the year in which the FY ends, e.g., FY 2018 ends on 16 July 2018.

8 Preliminary estimates by Central Bureau of Statistics for GDP growth.

9 ADB. Nepal Macroeconomic Update. April 2018, Nepal Budget 2019 Analysis. July 2018. Kathmandu, Nepal.

10 Remittance income increased at the rate of $20 \%$ in the last 10 years but increased by only $1.7 \%$ in the first seven months of FY2018. Deceleration of remittance inflows threatens to derail the economic stability, affecting household demand, revenue mobilization, banking sector liquidity, and foreign exchange reserves. Footnote 9.

11 The far-western and mid-western regions and the mountain districts have poverty rates well above $40 \%$. Poverty incidence is $27 \%$ in rural Nepal, compared with $15 \%$ in its urban areas. Socially disadvantaged groups such as Dalits experience substantially greater poverty than the rest of the population (Source: Nepal Country Partnership Strategy, 2013-2017). 
the deficit is estimated at $6.7 \%$ in FY2018. Tax revenue, although already high compared to similar economies in Asia, is barely enough to cover ballooning recurrent spending. ${ }^{12}$

The external current account balance reversed from a sizable surplus of $\$ 1.3$ billion in FY2016 to a deficit of $\$ 95.7$ million (0.4\% of GDP) in FY2017 and 8.2\% of GDP in FY2018. The persistently low capital expenditure (about 5.0\% of GDP on average in the past decade) and low export performance (5.7\% of GDP compared with imports equivalent to $31 \%$ of GDP) marks the underlying weaknesses undermining Nepal's growth prospects. ${ }^{13}$ Although the country has a high growth potential, it has been constrained by political transition, an infrastructure deficit, an unfavorable investment climate, and overall weak governance characterized by cumbersome bureaucratic procedures, weak PFM, procurement and contract management, and poor transparency and accountability. ${ }^{14}$

On the monetary front, inflation has been stubbornly high, averaging $9 \%$ in the last decade largely due to supply-side constraints, including anti-competitive practices. Inflation has been moderating (4.5\% in 2017 and $4.1 \%$ in 2018) largely on the back of subdued inflation in neighboring India, increased domestic output, ease in the supply of goods, and moderate oil prices. Total external debt stood at $17.4 \%$ of GDP in FY2018, up from 15.7\% of GDP in FY2017. External debt is largely long-term at concessional rates from multilateral financial institutions and bilateral donors. External debt service is equivalent to $8.3 \%$ of exports of goods and nonfactor services. The 2017 debt sustainability analysis places Nepal at low risk of debt distress. The White Paper 2018 presented by the Ministry of Finance exhibits several challenges in macro-economic performance over the last decade. ${ }^{15}$

\section{B. Governance and Institutional Arrangements}

\section{Policy and planning instruments and processes}

The Constitution of Nepal provides the legal framework and basis for policy formulation. There is a formal procedure in preparing and endorsing legal acts. Preparation of bills may be initiated by individual members of the LegislatureParliament or the executive branch such as the Prime Minister and his or her Cabinet members. Drafting committees are formed to draft bills. The Ministry of Law and Justice, and Law Commission play important roles in drafting bills. A proposed bill is discussed extensively in the Parliament before it is approved, which then becomes an Act following endorsement by the President. Necessary policies, regulations, and guidelines are then developed by sector ministries in line with the relevant acts. Many laws and policies have been formulated as a part of the obligations of the ratification of international treaties.

National Planning Commission (NPC), the Ministry of Finance (MOF), and the sector ministries are responsible for development

12 Footnote 9. Data in mid-February 2019 show that trade deficit has surpassed the net invisible earnings, widening the current account deficit to $\$ 1.5$ billion, slightly up from a deficit of $\$ 1.4$ billion in the year earlier. The current account deficit is rising and projected to widen further to $9.3 \%$ of the GDP because of increasing imports.

13 The existing level of capital expenditure is inadequate compared with the requirement of 8.0-12.0\% of GDP to close Nepal's infrastructure gap in the next 10 years, as estimated by P.L. Andres, D. Biller, and M. Herrera Dappe. World Bank. 2013. Reducing Poverty by Closing South Asia's Infrastructure Gap. Washington, D.C.

14 Footnote 9. The data presented in the paragraph that follows was also taken from ADB's Nepal Macroeconomic Update and Nepal Budget 2019 Analysis.

15 Government of Nepal, Ministry of Finance. 2018. White Paper on State of Economy. Kathmandu. 
planning and budgeting. Periodic 3-year plans provide a basis for the government to frame the annual budget and guide development work in the country. Planning is done using the midterm expenditure framework in line with sector strategies and business plans. ${ }^{16}$

An annual budget is prepared by MOF based on the periodic plan. A resource committee prepares the budget forecast, sets the budget ceiling, and prepares budget formulation guidelines. Sector ministries then submit budgets to MOF and NPC based on the ceiling and as per the guidelines. The budget is then presented in Parliament for approval. As autonomous governments, SNGs follow their own policy and planning processes although they are also guided by the national framework. ${ }^{17}$ Proposed development programs and projects are discussed in respective provincial councils and are approved in line with the budget ceiling.

\section{Existence and enforcement of legal and regulatory frameworks}

The Constitution of Nepal guarantees the independence of the judiciary. Nepal rose five positions from 63rd in 2016 to 58th out of 113 countries and secured the first place out of six countries in the South Asia region on overall rule of law performance in the 2017-2018 Rule of Law Index released by the Washington-based World Justice Project. ${ }^{18}$ The Worldwide Governance Indicators 2016, however, ranked Nepal in the bottom 20th percentile for rule of law out of more than 200 countries.

There are constitutional checks and balances on the executive in Nepal. Laws and regulations are not changed arbitrarily and are publicly available. Although changes in governments have been frequent, Cabinet decisions once taken have rarely been rolled back by subsequent governments, even when ideological differences prevail. Ministries responsible for the necessary changes in legislation are required to follow administrative and political procedures, including public consultations when amending laws. Regulatory bodies are fairly independent (in principle) but remain weak operationally. While appointments to these organizations are supposedly merit-based, they are nominated by political parties, often based on affiliation rather than competence. Nepal did poorly in the Worldwide Governance Indicators 2016 on regulatory quality, with a percentile rank of 23.6, which is only marginally better than Bangladesh (22.1) but lower than other countries in South Asia. ${ }^{19}$

\section{Structures and functions of the branches of government and their interactions}

Table 1 provides information on structures and functions of government institutions. An overview of Country Governance Systems for Nepal based on various governance surveys undertaken by international agencies and institutions is presented in Appendix $2 .{ }^{20}$

16 Education and health are the only sectors that have national sector strategies, while others have only business plans which are being strengthened for conversion into sector strategies (e.g., agriculture sector strategy).

17 Province No. 3 has established its own planning commission, whereas other provinces are yet to establish theirs. They may also choose not to establish a planning commission and may adopt different planning modalities.

18 https://worldjusticeproject.org/sites/default/files/documents/WJP_ROLI_2017-18_Online-Edition_0.pdf.

19 http://info.worldbank.org/governance/wgi/\#home.

20 Based on various governance surveys done by international agencies and institutes. 
Table 1: Government Institutions and Their Functions

\begin{tabular}{ll}
\hline & \multicolumn{1}{c}{ Legislative } \\
$\begin{array}{ll}\text { State Management } \\
\text { Committee and }\end{array}$ & Authority to enquire about issues of financial or management irregularities. \\
$\begin{array}{l}\text { Public Accounts } \\
\text { Committee }\end{array}$ & The committees can summon ministers or civil servants to committee hearings for \\
\hline
\end{tabular}

Fiduciary

Supreme Court Highest judicial body comprised of a Chief Justice and no more than 14 judges.

Additional judges (up to 10) may be appointed for a fixed term as needed.

On the recommendation of the Constitutional Council, a Chief Justice is appointed for

6 years. The Chief Justice then appoints other judges on the recommendation of the Judicial Council.

Special Court A three-program and project-member court comprising a chairperson and two judges of appellate level.

Adjudicate cases of corruption. Its decisions can be appealed to the Supreme Court.

It also tries offenses against the state and cases of money laundering.

District Court A trial court with jurisdiction to hear all civil and criminal cases.

Each of Nepal's 75 districts has a court.

The Chief Justice appoints District Court judges.

Administrative Court A three-program and project-member court constituted under the Civil Service Act 1992.

It hears appeals of departmental actions.

The chair is a serving or retired judge of the Court of Appeals.

Labor Court

Constituted under the Labor Act 1991.

Hears appeals of decisions relating to payment of salaries, allowances, gratuities, and provident funds. The court also hears appeals of decisions of management or company officials.

\begin{tabular}{|c|c|}
\hline Attorney General & $\begin{array}{l}\text { Chief legal adviser to the government. The President appoints the Attorney General } \\
\text { on the recommendation of the Prime Minister. The appointee holds office during the } \\
\text { tenure of the Prime Minister and represents the government in court. }\end{array}$ \\
\hline $\begin{array}{l}\text { Judicial Service } \\
\text { Commission }\end{array}$ & $\begin{array}{l}\text { Recommends appointments, transfers, and promotion of officers in the judicial service. } \\
\text { However, examinations for appointment of class III judicial officers are conducted by PSC. }\end{array}$ \\
\hline & Executive \\
\hline The President & $\begin{array}{l}\text { Head of State. Main responsibility is to protect the Constitution. } \\
\text { All bills passed by Parliament become laws upon approval by the President. } \\
\text { The President may ask the government to reconsider a bill but has no authority to reject it. }\end{array}$ \\
\hline The Prime Minister & Chief executive of the government. \\
\hline $\begin{array}{l}\text { Office of the Prime } \\
\text { Minister and the } \\
\text { Council of Ministers }\end{array}$ & $\begin{array}{l}\text { Provide leadership to the civil service. } \\
\text { Direct and supervise its performance and make the bureaucracy active and efficient. } \\
\text { Lead governance reforms. }\end{array}$ \\
\hline $\begin{array}{l}\text { Public Procurement } \\
\text { Monitoring Office } \\
\text { under the Office } \\
\text { of the Prime Minister } \\
\text { and the Council } \\
\text { of Ministers }\end{array}$ & $\begin{array}{l}\text { Established as per the provision made in the new Public Procurement Act. } \\
\text { Formulation and enforcement of public procurement laws, policies, and guidelines. } \\
\text { Monitoring of procurement processes and contract management. } \\
\text { Custodian of e-program and project government procurement (e-program and project } \\
\text { GP) system. Provide orientation and training on public procurement and e-program } \\
\text { and project GP. }\end{array}$ \\
\hline
\end{tabular}




\section{Department for Revenue Investigation}

Anti Program and Project Money Laundering Department Ministry of Finance

Financial Comptroller General's Office (under Ministry of Finance)

\section{National Planning Commission}

Resource Committee

Institute of Chartered of Nepal

Nepal Rastra Bank (Central Bank)
Ministry of Law and Justice

Ministry of Federal Affairs and Local Development
Established under Investigation and Control Act 1996 and under the Office of the Prime Minister and the Council of Ministers.

Control revenue leaks and misuse of foreign exchange.

Established under Anti Program and Project Money Laundering Act 2008 and under the Office of the Prime Minister and the Council of Ministers.

Investigate and prosecute cases of antiprogram and project money laundering and financial crimes.

Nation's financial manager, with oversight of revenues and expenditures, budget preparation, and responsibility for maintaining a stable economy.

Mobilizing and allocating resources, managing public investments and expenditures and strengthening the productive capacity of public enterprises.

Oversees all government expenditures and consolidating financial statements.

Manages a cadre of accountants, who are deployed to government agencies to provide accounting functions.

Tracks revenue collection and computes other receivables, releases budgeted funds to government agencies on a quarterly basis, and carries out their internal audits through District Treasury Comptroller's Office.

Submits government's annual consolidated financial statement to the Office of the Auditor General, with details of total expenditures, virements, and the position of the government treasury.

Ensure monetary and financial stability in coordination with the Ministry of Finance. Committee chaired by the Minister of Finance recommends appointment of the Governor. Main functions: issuing currency, formulating and implementing appropriate monetary policy and foreign exchange policy and systems, issuing banking licenses, regulating commercial banks and financial institutions and serving as their banker. Also functions as the government's banker, adviser and financial agent.

A planning body appointed by the Cabinet

Formulation of national vision, periodic plans and development policies. It provides a framework for policy for all sectors and serves as a central agency for monitoring and evaluating development plans, policies and programs.

Members from MOF, NPC and the Central Bank. Prepares budget forecasts, sets the ceiling, and prepares budget formulation guidelines.

Drafts bills, ordinances and executive orders, reviews and updates existing laws. It provides legal opinions to the government and edits notices for publication in the Nepal Gazette.

The General Administration arm is responsible for central and federal civil service personnel management and record keeping.

Formulates, implements and reviews plans, policies, and programs for recruitment, placement, promotion, salary, allowance, disciplinary action and retirement of civil servants.

All ministries, departments, commissions, and central level offices need its approval before taking any action related to civil service management.

The federal affairs arm is responsible for coordination among all government tiers related to federalism issues. 
Table 1 continued

Sector Ministries

Departments

National Vigilance

Center
Formulate sectoral policies and plans to implement decisions and directives of the government through various central and field level administrative mechanisms (e.g., departments).

Monitor and evaluate program implementation.

Ministries prepare policies or programs and evaluate them from social, economic, administrative, legal and financial perspectives.

Ministries coordinate with other agencies and stakeholders and, following revisions, submit a final policy or program to the Cabinet for approval.

Implement approved programs and policies, supervise and coordinate field offices, develop technical skills, provide advice to the ministry and ensure effective service delivery.

Established under the direct supervision and control of the Prime Minister in accordance with the Control of Corruption Act 2002.

Main task is to promote integrity and good governance and prevent corruption.

Monitors incomes and individual property statements of public servants

(asset declaration).

Undertakes technical audits of projects to check compliance with laws, regulations and standards.

Besides permanent offices (ministries, departments), government can create offices for specific projects and functions when existing administrative arrangements are unsuitable for a task at hand.

\section{Constitutional Bodies}

Commission for Investigation of Abuse of Authority

(CIAA)

Office of the Auditor General

\section{Public Service \\ Commission}

Authority to investigate abuse of authority and unlawful gains by public officials, including political appointees.

It has 10 regional and liaison field offices. Where $\mathrm{CIAA}$ does not have a presence (e.g., remote districts), the authority to address corruption is delegated to Chief District Officers.

If a person is found guilty, CIAA can file a case in court or recommend departmental action by the relevant authority. It also advises the government on policies and laws to curb corruption.

CIAA commissioners are appointed by the President on the recommendation of the Constitutional Council for a period of six years.

The CIAA submits an annual report to the President, which is discussed in the governance committee of Parliament.

Audit finances of all government offices, including the judiciary and the legislature.

The Constitutional Council recommends the Auditor General, who serves for a period of 6 years or until the retirement age of 65 .

PAC discusses the Auditor General's annual report on behalf of Parliament.

The government is required to consult the Public Service Commission on all matters related to personnel management, especially the terms and conditions of service and the principles to be followed in recruitment, promotion, and departmental action against civil servants. Its main task is to conduct examinations for selecting candidates to fill vacant positions.

Teacher's Service Commission program and project approved positions at public schools and recommend promotions.

Source: The Asia Foundation. 2012. A Guide to Government in Nepal. Kathmandu and organizations' websites. 


\section{Country Development Strategies}

The government's development strategy is outlined in the most recent development plan, the Fourteenth Three Year Plan (FY2017-FY2019), which is currently under implementation. It aims to achieve socioeconomic transformation and reduce poverty through high economic growth, productive employment, and fair distribution. The plan's strategic priorities include:

(a) developing infrastructure in energy, roads and air transport, information and communications networks, and ruralurban and transnational connectivity;

(b) increasing output through agricultural transformation and the expansion of tourism, industries, and small and medium-sized enterprises; and

(c) extensive, sustainable improvement in human development with a focus on social development and social protection.

The plan places equal importance on crosscutting issues such as good governance, gender equality and inclusion, the environment, and institutional capacity. The Fourteenth Plan also envisages meeting the United Nations Sustainable Development Goals by 2030. While the Fourteenth Plan lays out development strategies at the national level, it does not include plans of the SNGs under the new federal structure as this was conceptualized before the SNGs were instituted. The SNGs have their own plans and strategies but are aligned with the national framework.
The FY2019 budget of $\$ 13.15$ billion (39\% of GDP) will be financing the last year of the Fourteenth Plan. The increased allocation for recurrent and capital expenditures including fiscal transfers to the SNGs led to the larger budget for FY2019. Of the total budget, the projected revenue and grants for FY2019 is only $\$ 8.90$ billion (an estimated $26.3 \%$ of GDP), which leaves a budget deficit of $\$ 2.69$ billion (an estimated $8 \%$ of GDP) and will be financed by domestic and foreign borrowing and grants. The 2019 budget has also created a base to implement the federal system in the country. ${ }^{21}$

The United Nations in Nepal has come up with its latest development assistance framework (2018-2022) to support the implementation of the Sustainable Development Goals (SDGs). Nepal needs further and extensive financial and technical support to implement SDGs. The World Bank Group's new country partnership framework for Nepal covers a 5-year period (FY2019-2023) and focuses on support to implement federalism. Drawing from its Systematic Country Diagnostics report, the country partnership framework focuses on three transformative engagement areas:

(a) public institutions,

(b) private sector-led jobs and growth, and

(c) inclusion and resilience. ${ }^{22}$

In line with the country partnership framework, the International Finance Corporation program in Nepal plans to focus on financial inclusion, sustainable infrastructure, including power and connectivity, and sectors that contribute to growth. A matrix of development partner supported programs and projects (ongoing and pipeline) is provided in Appendix 3.

21 Government of Nepal, Ministry of Finance. 2019. Nepal Budget FY2019. Kathmandu.

22 The World Bank. 2018. The World Bank groups' Country Partnership Strategy for Nepal FY 2019-FY 2023. Washington DC. http://documents.worldbank.org/curated/en/394651533563569169/pdf/129253-WP-P165117-PUBLIC-TwoPager-CPF-062818.pdf. 


\section{III.}

\section{ASSESSMENT OF COUNTRY SYSTEMS}

A s Nepal is transitioning from a unitary to a federal system of governance, this report assesses the changes in institutional arrangements as well as assessments in PFM, procurement, and corruption.

\section{A. Institutional Arrangements in the Federal Structure}

The new constitution has assigned larger functional, semi-judicial, and fiscal authority to elected SNGs. An organization and management survey was undertaken by the federal government to assess the current organizational structure and recommend new structures in line with the functional assignment of different tiers of government as per the constitution. ${ }^{23}$ Based on the findings of the survey, public institutions at the federal level have been merged and restructured and organizational structures for SNGs, particularly the provincial governments, have been recommended. Most sector ministries and departments at the federal level have been downsized as several functions have been devolved to the SNGs. Due to the institutional restructuring, the executing and implementing agencies of some ongoing ADB projects and programs have been changed. Also, some programs and projects previously implemented by the federal government will now be implemented by provincial and local governments. Appendix 4 provides further details on these changes.

While the 2015 constitution provides the national legal framework for federalism, each government tier needs to enact several laws for them to undertake their mandates. Although the SNGs have the constitutional right to make their own laws given their autonomous status (and not hierarchical), the constitution has clearly stated that the laws of all government tiers should be aligned and not conflict with each other so that possible disputes between and among the federal, provincial, and local governments can be avoided.

While several laws have been enacted, such as the Local Government Operations Act, ${ }^{24}$ Intergovernmental Fiscal Arrangements Act, ${ }^{25}$ and the National Natural Resources and Fiscal Commission Act 2017, ${ }^{26}$ the legal framework to implement federalism is yet to be completed. Given the weak institutional capacity of SNGs to draft their own laws, the federal government has been providing model laws to SNGs which they can modify as appropriate.

23 An organization and management survey committee under the Ministry of Federal Affairs and General Administration was formed by the Cabinet in March 2018.

24 The Local Government Operations Act, 2017 describes the structure, roles, responsibilities and interrelationships among government tiers of the local governments, including that of the District Coordination Committees, which have a coordinating role for development activities within a district.

25 The Inter-Governmental Fiscal Arrangements Act provides a framework arrangement for fiscal relationships among the various levels of government to address vertical and horizontal imbalances.

26 The National Natural Resources and Finance Commission Act provides an objective basis for revenue sharing and equalization grant allocation to SNGs. 
Some key challenges and risks are summarized below.

(a) Weak public institutions and service delivery. With the devolution of functions to SNGs, regional and district offices previously under federal sector ministries have been closed. This has disrupted service delivery as the provincial governments are only newly established and local governments do not have adequate institutional capacity to undertake all the assigned functions. The functioning of the SNGs has also been affected by the lack of human resources and low capacity of several staff members. The Staff Adjustment Act, 2017 allows the federal government to reallocate government staff previously under the federal government to SNGs but the process has been unduly long for various reasons, including staff resistance to go to SNGs in remote locations, unavailability of quality services (schools, hospitals), and the perception that those assigned to SNGs are low performers. ${ }^{27} \mathrm{~A}$ new federal civil service law is also yet to be enacted. The SNGs will then formulate their civil service acts in line with the federal act.

(b) Concurrent rights and powers and overlaps among government tiers. Clear demarcation of functional assignments and authority, and coordination among all government tiers are important and urgent. A summary of exclusive and concurrent rights and responsibilities of the three government levels is provided in Appendix 5.

Functions of local governments and provincial governments are detailed in Appendixes 6 and 7. (c) Absence of a well-functioning fiscal federalism framework. One critical component for the successful implementation of federalism is a good fiscal federalism framework comprising objective mechanisms for equitable distribution of resources across the three tiers of government while building local government capacity to mobilize their own revenues and execute new service delivery and administrative mandates without compromising fiscal discipline. This is discussed under the fiscal federalism section below.

Multiple donors are supporting Nepal's federalization and institutional restructuring process. The World Bank has provided two Development Policy Credits (2018-2019) for budgetary support with the aim of supporting federalism, including fiscal decentralization and public financial management reforms. Several donors have pledged support to a Provincial and Local Governments Capacity Development Program, which is mainly targeted for capacity building and institutional strengthening of SNGs. Various UN agencies have been providing technical and knowledge support to implement federalism. Donor support in this regard is presented in the donor mapping matrix (Appendix 3). A consortium of development partners, the Federalism Working Group, has been formed to help coordinate the federalism agenda and support to the government.

ADB Nepal is an active member in this group.

Institutional development and strengthening of public institutions, particularly at the SNG level, is a key reform priority for the efficient implementation of federalism and where ADB could provide policy advisory and technical support through its programs and projects. 
Some of the proposed reform activities are as follows:

\section{(a) Assessment of institutional} arrangements for ongoing projects and programs. The devolution of sector functions and the subsequent changes in institutional arrangements under the federal structure have implications for ADB operations, particularly those implemented at the subnational levels (e.g., urban and water projects, education programs, agriculture projects, provincial highways and local roads, and small-scale energy projects). It is therefore important to review the institutional arrangements of the ongoing projects and programs affected and make necessary adjustments.

(b) Development of an institutional strengthening plan. All future projects and programs should undertake an institutional assessment of executing and implementing agencies, and an institutional strengthening plan as the new federal context must be developed, integrated, and implemented through sector programs and projects. This should also include capacity development plans based on the mandates and needs of the agencies. Appropriate technical and policy advisory support for the implementation of these plans should then be included in projects and programs and should be regularly followed up during review missions and progress reported..$^{28}$ It is also crucial for project teams to hold consultations with SNGs to discuss planned and proposed projects and programs as part of the project and program processing. This will also help in building ownership and support of the SNGs, which is fundamental for their smooth implementation.

\section{B. Public Finance Management}

The 2015 report of the Public Expenditure and Financial Accountability Secretariat (PEFA) indicated that out of 28 performance indicators, 16 improved, 10 remained unchanged, and two deteriorated, which shows an overall improvement in PFM. A comparison of PEFA 2015 scores with other countries shows that Nepal's PEFA ratings are better than the average of 15 fragile states and 27 low-income countries. Compared to the average of 51 middle-income countries, the Nepal PFM system rating is better or equal on four dimensions and its rating is lower on two (external scrutiny and audit, and comprehensiveness and transparency). ${ }^{29}$ A summary of PEFA ratings for all 31 indicators is provided in Table 2 and a summary of PEFA 2015 findings is in Appendix 8.

28 As per the Inter-Governmental Fiscal Arrangements Act, 2017. A new foreign aid policy is being considered to facilitate federal transition of foreign assistance.

29 Government of Nepal, Ministry of Finance. 2015. Public Expenditure and Financial Accountability Assessment. Kathmandu. 
Table 2: Summary of Public Expenditure and Financial Accountability Ratings in 2008 and 2015

Assessment Areas

1. PFM OUTTURNS Credibility of the budget result

2. KEY CROSSCUTTING ISSUES

Comprehensiveness and transparency

\section{BUDGET CYCLE}

(i) Policy-based budgeting

(ii) Predictability and control in budget execution

(iii) Accounting, recording, and reporting

(iv) External scrutiny and audit

\section{DONOR} PRACTICES

\section{Specific Indicators}

\section{Grade}

20082015

PI-1 Aggregate expenditure outturn compared to original approved budget.

B A

$\mathrm{PI}-2$ Composition of expenditure outturn compared to original approved budget.

PI-3 Aggregate revenue outturn compared to original approved budget.

C $\mathrm{C}+$

$\mathrm{Pl}-4$ Stock and monitoring of expenditure payment arrears.

A $\quad A$

$\mathrm{PI}-5$ Classification of the budget.

$\mathrm{D}+\mathrm{B}+$

PI-6 Comprehensiveness of information included in budget

C A documentation.

PI-7 Extent of unreported government operations.

PI-8 Transparency of intergovernmental fiscal relations.

PI-9 Oversight of aggregate fiscal risk from other public sector entities.

B A

$\mathrm{PI}-10$ Public access to key fiscal information.

$\mathrm{PI}-11$ Orderliness and participation in the annual budget process.

$\mathrm{PI}-12$ Multi-year perspective in fiscal planning, expenditure policy and budgeting.

PI-13 Transparency of taxpayer obligations and liabilities.

PI-14 Effectiveness of measures for taxpayer registration and tax assessment.

PI-15 Effectiveness in collection of tax payments.

C D +

C $\mathrm{C}+$

$\mathrm{D}+\mathrm{C}$

B A

C+ A

$\mathrm{C}+\mathrm{B}$

$C+A$

C A

PI-16 Predictability in the availability of funds for commitment of expenditures.

PI-17 Recording and management of cash balances, debts and guarantees. $\quad \mathrm{C}+\mathrm{C}+$

PI-18 Effectiveness of payroll controls.

$\mathrm{C}+\mathrm{C}+$

$\mathrm{PI}-19$ Competition, value for money and controls in procurement.

$\mathrm{PI}-20$ Effectiveness of internal controls for nonsalary expenditure.

PI-21 Effectiveness of internal audit.

C B

C C

$\mathrm{D}+\mathrm{D}+$

$\mathrm{PI}-22$ Timeliness and regularity of accounts reconciliation.

C+ C+

$\mathrm{Pl}-23$ Availability of information on resources received by service delivery $\quad$ C A units.

PI-24 Quality and timeliness of in-year budget reports.

$\mathrm{C}+\mathrm{C}+$

PI-25 Quality and timeliness of annual financial statements.

$\mathrm{C}+\mathrm{C}+$

PI-26 Scope, nature and follow-up of external audit.

$\mathrm{D}+\mathrm{C}+$

PI-27 Legislative scrutiny of the annual budget law. $\quad D+D$

PI-28 Legislative scrutiny of external audit reports.

D $\quad \mathrm{D}$

D-1 Predictability of direct budget support.

D D+

D-2 Financial information provided by donors for budgeting and reporting $\quad$ D $\quad$ C + on project and program aid.

D-3 Proportion of aid managed by use of national procedures.

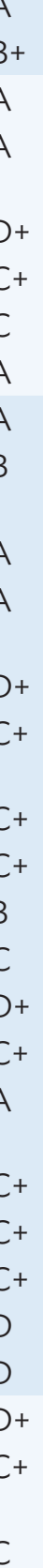

Source: Government of Nepal. Ministry of Finance. 2015. PEFA Assessment: Nepal PFM Performance Assessment II as of FY 2013-2014. Kathmandu. http://www.mof.gov.np/uploads/document/file/PEFA\%201I\%20Final\%20Report\%20 May\%202015_20150623043447.pdf. 
The Constitution of Nepal provides the overarching legislative framework for financial procedures to all government levels. The legal framework to execute PFM functions is provided in Table 3.

Regarding financial institutions, responsibilities for PFM lie in (i) Parliament's Public Accounts Committee as an oversight body for overall fiscal discipline and management; (ii) MOF for budgeting, accounting, treasury management, and domestic and external debt management; (iii) NPC for resource planning; (iv) Financial Comptroller General's Office for treasury management, including financial record keeping, reporting, and internal auditing; and ( $v$ ) the Office of the Auditor General (OAG) for external auditing. More information on the functions of these institutions is provided in Table 1 in Chapter II Country Overview.

Budget preparation starts with the issuance of a joint circular by the NPC and MOF with budget ceilings and guidance 4 months before the start of the new fiscal year. The budget formulation guideline contains all necessary information and guidance for ministries, departments, and agencies on budget preparation, including calculators for respective data requested under budget request forms. The finance minister

\section{Table 3: Public Finance Management Legal Framework}

\begin{tabular}{|c|c|}
\hline PFM Areas & Legal Instruments and Functions \\
\hline \multirow[t]{3}{*}{$\begin{array}{l}\text { Financial } \\
\text { management }\end{array}$} & $\begin{array}{l}\text { Financial Procedural Act (1999) prescribes financial procedures relating to collection, } \\
\text { disbursement, recording, internal control, internal and external audits, and actions on } \\
\text { irregularities. }\end{array}$ \\
\hline & $\begin{array}{l}\text { Good Governance Management and Operation Act (2008) requires public } \\
\text { administration to be pro-people, accountable, transparent, inclusive, corruption-free, } \\
\text { comply with rules and regulations, and provide efficient public service delivery. }\end{array}$ \\
\hline & $\begin{array}{l}\text { c) Local Governance Operations Act (2017) supports local financial management } \\
\text { and requires local governments to develop and implement their own internal control } \\
\text { and other systems. The Fiscal Responsibility and Budget Management Act, which is } \\
\text { currently being drafted, aims to institutionalize financial discipline, reduce fiscal deficit, } \\
\text { and strengthen fiscal prudence. }\end{array}$ \\
\hline $\begin{array}{l}\text { Revenue } \\
\text { administration }\end{array}$ & $\begin{array}{l}\text { Income Tax Act (2002), Value Added Tax Act (1996), Customs Act (2007) and Excise } \\
\text { Duty Act (2002) govern revenue administration. Various rules, guidelines, and directives } \\
\text { support the implementation of these laws. }\end{array}$ \\
\hline \multirow{3}{*}{$\begin{array}{l}\text { Debt } \\
\text { management }\end{array}$} & (a) Loan and Guarantee Act (1968) provides the legal framework for foreign loans. \\
\hline & $\begin{array}{l}\text { Public Debt Act (2002) provides the framework for issuance and servicing of } \\
\text { government securities. }\end{array}$ \\
\hline & $\begin{array}{l}\text { (c) As per the Central Bank Act (2002), the Central Bank is the manager of government } \\
\text { and advises on formulating the annual borrowing program. }\end{array}$ \\
\hline $\begin{array}{l}\text { Borrowing } \\
\text { by local } \\
\text { authorities }\end{array}$ & $\begin{array}{l}\text { Local Governance Operations Act (2017) allows local authorities to raise credit and loans } \\
\text { with or without pledging any property under its ownership and possession or under guarantee } \\
\text { by the government, a bank or any other organization, according to the policy approved by the } \\
\text { local authority. }\end{array}$ \\
\hline $\begin{array}{l}\text { Audit } \\
\text { and oversight }\end{array}$ & $\begin{array}{l}\text { The Office of Auditor General is mandated to undertake audits as provisioned under the } \\
\text { Audit Act (1991). A parliamentary committee discusses the OAG reports and monitors } \\
\text { progress on budget implementation. }\end{array}$ \\
\hline
\end{tabular}

Source: Nepal Law Commission http://www.lawcommission.gov.np/en/ and Ministry of Finance. www.mof.gov.np. 
submits the proposed budget to Parliament for approval a week before the start of the fiscal year. It takes 2 months for Parliament to pass the budget and obtain the President's endorsement. ${ }^{30}$

The budget formulation is based on administrative, economic, and subfunctional classifications using government finance statistics. Gender responsive, pro-poor, climate change, and the strategic pillars of the periodic plan are also used to classify the budget. The budget speech is uploaded to the MOF website immediately upon its presentation in Parliament. Similarly, the NPC publishes and makes available on its website the midterm expenditure framework, and programs and projects within a month of budget presentation. ${ }^{31}$

Compared to the 2008 PEFA ratings, performance in budget formulation has improved (from C in 2008 to $A$ in 2015) owing to effective use of functional and economic classification according to government finance statistics standards, and budget documentation being more comprehensive. The Open Budget Survey has indicated improvements in budget transparency in Nepal (a 52\% score in 2017 compared to $24 \%$ in 2015, and $44 \%$ in 2012). This is moderately higher than the global average score of $42 \%$ and the highest among the South Asian countries.

There are clear legal provisions, systems, and processes to guide and to enforce budget commitment controls. More than 4,000 spending units carry out budget execution. The rollout of the Treasury Single Account system at the national and local level prior to the federal structure has enabled the government to centralize the payment function at District Treasury Controller Offices (DTCOs) and strengthen cash management by closing 13,717 bank accounts. The DTCO releases funds after ensuring that the recommended payments and supporting documents are in conformity to the rules. This system now supports the compilation of consolidated cash flow statements for the central government and individual ministries. Monitoring the budget has also improved with the implementation of the Treasury Single Account. ${ }^{32}$

The government follows a cash-based accounting system and prepares consolidated financial statements in accordance with Nepal Public Sector Accounting Standards, based on international Public Sector Accounting Standards. ${ }^{33}$ The financial management information system has been developed and maintained by the Financial Controller General's Office (FCGO) to keep records of financial data. The FCGO prepares annual financial statements within six months and publishes the consolidated financial report, which is then submitted to OAG.

The current PFM system does not report outstanding commitments. Bank reconciliation for all treasury managed bank accounts takes place quarterly, usually within 8 weeks of the end of a quarter. Reconciliation and clearance of suspense accounts is practiced. There are

30 Alliance for Social Dialogue. 2014. A Description and Analysis of the Budget Formulation and Implementation Process in Nepal. Kathmandu.

31 While midterm expenditure frameworks are being produced and discussed, it is not used meaningfully for effective planning and budgeting. It was first introduced in 2002 but remained unused for years until it was reintroduced in 2015-2016.

32 The following data is available on the FCGO website: (a) daily budgetary status, (b) monthly ministry expenditure status, (c) monthly expenditure by economic classification, (d) monthly district budget execution, and (e) yearly consolidated financial statement.

33 The Accounting Standards Board has supported the development of the Nepal Public Sector Accounting Standards. It is yet to fully comply with International Public Sector Accounting Standards. 
clear provisions for settlement of advances in the accounting as per Financial Procedures Rules 2007.34 Management of advances has improved with the introduction of the Treasury Single Account (improved PEFA rating: B in 2015 compared to $C$ in 2008).

The internal audit unit in FCGO is responsible for conducting internal audits of all offices at the federal level. The FCGO through DTCOs is responsible for internal audits at the subnational and local levels. The recently enacted Local Government Operations Act 2017 makes it mandatory for SNGs to settle issues identified in the internal audit report before commencement of external audit and such internal audit reports need to be provided to the external auditors. The internal audit is required to cover all financial transactions and their processes, target achievements, and use of financial resources. A report on financial transactions is prepared by DTCO and submitted to the respective expenditure units.

The OAG, an independent constitutional oversight body, conducts financial and regularity audits on most government revenues and expenditures using the International Organization of Supreme Audit Institutions standards within 8 months after the end of a fiscal year and submits audit reports to the President. The report is publicly available as a published document and is posted on the website. PEFA assessments (PI 26-28) show that while external audit coverage and quality has improved, oversight and accountability remain weak (D).
The Constitution of Nepal provides the overarching legislative framework for financial procedures to all government levels. ${ }^{35}$ Substantial authority has been provided to SNGs by the new constitution. They have been given financial autonomy, including revenue raising power and expenditure allocation power. However, to effectively undertake this responsibility, they need supportive legal and institutional structures and adequate and skilled human resources. These pre-requisites are not sufficiently in place in many SNGs.

The Secretariat was established under MOF in 2005 following the first PEFA assessment. A national PEFA/PFM Steering Committee was then formed in 2009 to drive and coordinate PFM reforms. Nepal initiated some important PFM reforms, such as introduction of the midterm expenditure framework in resource planning, PEFA assessments in 2008 and 2015 were followed by the introduction of the Treasury Single Account in 2009, and subsequent development and implementation of PFM reform plans (PFMRP) Phase I 2010-2015, and PFMRP II 2016-2026, currently under implementation. Building on the PFMRP-I, a PFM Multi-Donor Trust Fund was established by the World Bank and some bilateral donors in 2010. ${ }^{36}$ Since then it has been supporting the government in improving the PFM system.

ADB, through its Strengthening Public Management Program (SPMP, 2012-2016) supported the government through the Ministry of Federal Affairs and General Administration

34 The Financial Procedures Manual 2007 mandates offices to settle advances within 21 days from the date of receipt of the statement along with bills and vouchers.

35 Subnational government includes both provincial and local governments.

36 Currently there are seven donors to the multi-donor trust fund: the European Union, the Department for International Development, Swiss Development Cooperation, the Governments of Norway and Denmark, Australia Department of Foreign Affairs and Trade, and the United States Agency for International Development. 
(MOFAGA) ${ }^{37}$ to implement some of the PFM reforms at the subnational and local government level as per the ministry's fiduciary risk reduction action plan developed to address local PFM challenges. ${ }^{38}$ SPMP was followed by a policy advisory technical assistance in 2017, which assessed institutional gaps in fiscal federalism and provided policy recommendations to the government for operationalizing fiscal federalism and improving PFM systems in the SNGs. It included comprehensive analysis, policy recommendations, and implementation strategies for improved accounting and reporting, internal control and internal audit, and external audit. ${ }^{39}$ The final report has been shared with the government and is a good reference for executing fiscal federalism and PFM reforms in SNGs.

In the absence of a sound PFM system (a) fiduciary risks will be increased, (b) project implementation will get delayed, (c) fiscal indiscipline will increase, (d) collusive and corrupt practices will go unnoticed and undetected, and (e) infrastructure and public services will be of substandard quality. Some of the major challenges in PFM that give rise to these risks are summarized below.

\section{(a) Institutional, legal, and policy} framework: Enforcement of laws and regulations; development of efficient systems and their use, including digitization of financial functions; and overall institutional strengthening of
PFM institutions, including a cadre of PFM experts and robust information management systems, are areas that need to be improved. Additionally, the change in governance structure from a unitary to a federal system requires the government to formulate several new laws in PFM and revise several existing laws in line with the new constitution.

(b) Budget formulation: There are no clear links between planning and budgeting. The midterm expenditure framework is used only for projects being implemented and not new projects. No transparent criteria exist for prioritizing project selection and financing. An analysis of the federal budget data of the last 5 years shows lack of clear prioritization of projects and programs leading to spending in nonprioritized areas and in new projects. Several projects are listed under priority (P1) projects without adequate justification and are considered mostly on political rather than strategic grounds. Moreover, MOF makes extra budgetary commitments of resources. Further, budget formulation is not based on realistic assumptions resulting in overestimation of expenditures, shortage of funds, underutilization of budgeted allocations, underestimation of nontax revenue receipts, and receipt of much lower actual grants than those estimated. ${ }^{40}$

37 The Ministry of Federal Affairs and General Administration was earlier called the Ministry of Federal Affairs and Local Development.

38 These included development and piloting of a comprehensive PFM IT system called Municipal Administration and Revenue System, community participation in local governance by financing projects prioritized by community forums, development and implementation of e-government procurement system, sub-national PEFA (for the first time in Nepal), risk based internal audit guidelines, and capacity development.

39 ADB. 2018. Technical Assistance to Nepal for Strengthening Sub-National Public Management. Manila.

40 Footnote 39. Parliament enacts the Appropriation Act each year, allowing Ministry of Finance to transfer the budget from one heading to another but not exceeding more than $10 \%$. 
(c) Budget execution: Fiscal indiscipline in budget execution has been a major concern. Although rules and regulations guide budget execution, widespread irregularities and weak enforcement has increased fiscal indiscipline. The OAG 2017 report highlighted high variances of up to 21 times. The 2015 PEFA report also indicated that the 10\% threshold for variance has been exceeded repeatedly. Bunching of capital expenditures (70\%) at the end of the fiscal year has become common in Nepal, leading to poor service delivery, increased fiduciary risks and poor quality infrastructure. ${ }^{41}$ Some reasons for this include the (i) absence of procurement plans in several procuring entities or not complying with these plans; (ii) unobjective costing of procurement plans, and lacking realistic timelines; (iii) approval and implementation of projects before they are fully prepared; and (iv) poor fiscal planning and management.

(d) Accounting and reporting: In the absence of a commitment accounting system, assets and liabilities are not fully accounted for and the scale and level of reported outstanding arrears is not accurate. The technical capacity of accountants also remains weak. Nepal's PEFA score in 2015 on accounting standards remained the same (C) as that in 2008. One reason for this was arguably the capacity constraints of accountants. The accounting system does not account for physical assets and their current market values. (e) Internal audit: Internal audit scored poorly (D) in PEFA 2008 and 2015. PEFA 2015 reported that inadequate staff resources, weak technical capacity, and FCGO's focus on providing accounting services rather than internal auditing contributed to continued weak internal control in government agencies. Also, there are issues related to conflicts of interest in internal auditing as internal auditors also function as account officers. The audit is undertaken annually and not every trimester as required and is not focused on internal control systems and their risks but is oriented toward identifying transactional irregularities, which reduces its effectiveness. ${ }^{42}$ DTCO submits audit reports with recommendations to unit managers, but hardly any actions are taken. Follow-up on recommendations is also weak and not systematically tracked. ${ }^{43}$ Poor internal control and internal audit increases fiduciary risk.

(f) External audit: Weak enforcement of corrective measures against flagged irregularities and recommendations of the OAG has been a persistent challenge. According to the OAG 2017 report, the scale of irregularities is on the rise (in absolute terms), and clearance of audit objections has been less than one-third, hence a huge audit backlog remains to be cleared. ${ }^{44}$

(g) PFM in SNGs: The overall PFM system at the SNG level, particularly the local government level, generally

41 Government of Nepal, OAG. 2018. OAG's 55th Annual Report. Kathmandu.

42 Government of Nepal, MOF. 2015. PEFA Assessment: Nepal PFM Performance Assessment II. Kathmandu.

43 The World Bank. Political Economy of Public Financial Management Reforms: Experiences and Implications for Dialogue and Operational Engagement. 2017.

44 Government of Nepal, OAG. 2017. Annual Report 2017. Kathmandu. 
exhibits (i) poor resource planning and management, (ii) poor or nonexistent internal audit and internal control, (iii) poor record keeping, (iv) ineffective external audit, ( $v$ ) lack of asset management systems [a budget for organization and management is hardly allocated], (vi) low levels of internal management supervision, (vii) absence of a consolidated financial management information system, (viii) nonuniform accounting systems and practices with different software used by different local governments, (ix) data on revenue collection by the SNGs is scanty and reporting is not done under the government financial statistics format, and ( $\mathrm{x}$ ) consolidated fiscal reports of SNGs are not prepared, which lowers the accountability of resource use. Furthermore, PFMrelated laws, policies and guidelines of the SNGs under the federal structure are yet to be formulated. It is not surprising, therefore, that the PEFA scores of local bodies before the federal structure were dominated by $C$ and D scores and that the pace of PFM reform has been slow. ${ }^{45} A$ summary of the subnational PEFA recommendations is in Appendix 9.

(h) Fiscal federalism: Given the large horizontal and vertical imbalances, SNGs will be fiscally dependent on federal transfers. Having a robust intergovernmental fiscal transfer framework with a grant allocation system based on a scientific formula is one of the main challenges in the new federal system of governance. Functional clarity on revenue and expenditure assignments among all the government tiers is yet to be established. It is critical to get these right as the inequality and perceived bias in grant allocation and revenue sharing can be contentious and could lead to political unrest. Implementation of fiscal federalism in SNGs is a huge challenge given their poor institutional capacity, weak PFM system, inadequate resources, and insufficient knowledge and experience.

(i) Sources of revenue: SNGs largely depend on central transfers as their own sources of revenue are negligible. This dependency will affect SNG's independent and autonomous status and due to scanty domestic revenue, they are unable to provide increased and quality public services. Different surveys have shown that, on average, local governments collect less than $2 \%$ of the potential domestic revenue. Domestic revenue mobilization (DRM) is hence a significant reform gap in fiscal federalism in Nepal. There are several factors that hinder SNGs to pursue DRM. These include the (i) absence of database of tax payers in their areas; (ii) clear functional assignment of revenue bases; (iii) legal framework and policies for tax administration, including tax rates, and compliance strategy; and (iv) possibility of using new and potentially imposable tax and nontax sources of revenue.

On the completion of PFMRP Phase I and based on the findings of PEFA 2015, FCGO and MOF developed PFMRP Phase II (2016-2026), which is currently under implementation. There are 119 reform action plans included in PFMRP II among which 23 are categorized

45 Government of Nepal, MOFAGA. 2016. Sub-National Public Expenditure and Financial Accountability. Kathmandu. 
as Immediate Priority. ${ }^{46}$ The PFM reform strategy is supplemented by agency-specific plans such as the OAG Strategic Plan 2016-2020 and Nepal Public Procurement Strategic Framework II 2013-2016. The Fourteenth Plan (FY 2017-2019) has also adopted a strategy to strengthen the PFM system, manage public expenditure and revenue systematically and transparently, and make internal control and audit trustworthy and effective. ${ }^{47}$ Implementation of some PFM reform activities is supported by some donors. The donor-supported PFM reform plans are largely concentrated at the federal level. The available technical and financial resources are inadequate to fulfill all the reform needs of SNGs. Table 4 presents these programs and projects.

Given the wide range of challenges and risks in PFM in Nepal, there are several reform needs, particularly in the newly established provincial governments and restructured local governments. Although FCGO-MOF's PFMRP II aims to undertake substantial PFM reforms at all government levels, it is yet to secure adequate financial and technical support for implementation.

Since the absence of a sound PFM system will increase fiduciary risk and give rise to collusive and corrupt practices which will jeopardize the implementation and quality of ADB projects, ADB should consider a PFM-focused program as a critical area of engagement. Given that a large concentration of donor-funded support in PFM is at the federal level and given the substantial number of challenges in SNGs under the federal governance system, it is recommended that $A D B$, in coordination with other development partners, support the Government of Nepal on subnational PFM reforms. Improved PFM in SNGs will support ADB's operations, mainly agriculture and

Table 4: Donor-Funded Reform Programs and Projects in PFM

\begin{tabular}{|c|c|}
\hline Donors/Amount/Period & Program and Project Activities \\
\hline DFID (\$6.5 million) 2019-2021 & $\begin{array}{l}\text { - Local governance PFM system strengthening } \\
\text { - Sectoral PFM reform } \\
\text { - Capacity building }\end{array}$ \\
\hline USAID (\$14 million) 2016-2021 & $\begin{array}{l}\text { - Improved PFM system in Ministries of Health and Education, } \\
\text { and National Reconstruction Authority } \\
\text { - Capacity building }\end{array}$ \\
\hline World Bank ( $\$ 150$ million) 2018-2019 & - Policy reforms, fiscal federalism and PFM \\
\hline $\begin{array}{l}\text { PFM Multi-Donor Trust Fund } \\
\text { (\$18 million) 2018-2021 }\end{array}$ & $\begin{array}{l}\text { - Support implementation of PFMRP II } \\
\text { - Strengthen PFM institutions, systems and procedures at the federal } \\
\text { and subnational level, including the OAG } \\
\text { - Public expenditure, revenue management in federal and } \\
\text { subnational governments } \\
\text { - Capacity building }\end{array}$ \\
\hline
\end{tabular}

DFID = Department for International Development, OAG = Office of Auditor General, PFM = public financial management, PFMRP = Public Financial Management Reform Program, USAID = United States Agency for International Development. Source: Federalism Working Group of Development Partners working in Nepal.

46 Government of Nepal, MOF. 2016. Nepal's Public Financial Management Reform Strategy/Program (PFMRP) Phase II (2017-2026). Kathmandu.

47 Government of Nepal, NPC. 2017. Fourteenth Plan (2017-2019). Kathmandu. 
natural resources, education, and urban and water sectors as most programs and projects under these sectors are implemented by SNGs under federalism. ADB should also consider using the recently introduced project readiness financing modality, particularly for projects that now fall under the supervision of the SNGs under the federal context. ${ }^{48}$ This will strengthen PFM practices and capacity in SNGs.

Additionally, it is recommended that (i) institutional arrangements for PFM at all government levels and (ii) potential risks are assessed for ongoing and pipeline projects in conjunction with institutional assessments as recommended in the earlier section. ${ }^{49}$ This will provide information on the implementation of the federal system (so far) and any specific reform measures that $A D B$ should be taking within the portfolio or in program and project design to facilitate implementation of the federal system or mitigation of PFM risks. The reform measures and priorities should then be implemented either through stand-alone programs, projects and TAs or through sector projects and programs or both. While it is more appropriate to analyze and determine specific reform activities following the assessment, a broad framework of support that would address the challenges and risks discussed earlier is provided below:

(a) Improved resource planning and management: Establishment of a program and project bank will enhance links between plans and budgets so SNGs may consider developing project banks, including sector categorization and prioritization of projects based on objectively defined criteria, including number of beneficiaries, social impact, and economic returns. The project bank should include resource needs (people with skills, financial, technical), and a list of activities related to project preparedness regarding the planned projects short, medium, and long term. This needs to be followed by preparation of realistic procurement plans. The project bank needs to be linked to multi-year budgeting. ADB is recommended to provide advisory and technical assistance support to SNGs for this through ongoing projects and programs or make provisions for this in new projects and programs. Internal coordination among sectors within ADB as well as coordination with development partners is important to avoid duplication and to support a large number of SNGs.

Institutionalization of this reform will enhance (i) efficient and effective use of resources, (ii) reduce fiduciary risks, (iii) improve project planning and management, (iv) promote strategic development approaches and improve transparency and accountability, (v) reduce fiscal indiscipline, and (vi) disallow inclusion of "pocket projects" in the plan based on political connections. Capacity development should be an integral part of the reform plan.

(b) Internal control: Robust internal control is fundamental for an effective and efficient PFM system and to reduce fiduciary risks. As highlighted by PEFA assessments (national and subnational), internal control and audit in Nepal needs to be improved significantly. ADB supported policy

48 ADB. 2018. Proposal for ADB's New Products and Modalities. Manila.

49 PFM assessment should be undertaken in coordination with ADB's Public Financial Management Division. 
and advisory technical assistance has provided a comprehensive internal control framework and implementation strategy to enhance internal control and internal audit for SNGs and is recommended for use as a reference to integrate appropriate reform activities in projects and programs along with disclosure of the closing inventory value in the account notes. ${ }^{50}$ Additionally, ADB together with other development partners shall have a policy dialogue with the government to separate cadres of accountants and internal auditors to address the issue of conflict of interest.

(c) Digitization of PFM system, including information management system: Operationalization of information and communication technology (ICT) systems in PFM could play a transformative role in enhancing transparency and accountability, increasing efficiency in the allocation and use of funds, and reducing fiduciary risks. Development and implementation of a suitable PFM ICT system in all SNGs is hence a priority. This can be achieved only with robust implementation strategies that complement the government's vision of automating SNGs. It is recommended that a single comprehensive financial system is implemented across all 753 local governments which will ensure uniformity in financial management and will help in monitoring and undertaking financial analysis for future policy formulations and revisions and grant allocations. Again, capacity development needs to be an integral part of the reform plan. If the government plans to execute digitization on its own or with the support of other development partners, then ADB should still stress its importance during consultation and review meetings and when having policy dialogues so this is expedited.

(d) Asset management system: Establishing an asset management system is an important reform that $A D B$ could support. SNGs need to be encouraged to account for the assets in their financial statements, and prepare fixed assets reports annually. It is recommended that ADB's program and project review missions include review of asset management systems and organization and management status as well.

(e) Fiscal federalism: Preparing and implementing a well-functioning fiscal federalism framework with equitable distribution of resources across the three tiers of government, both in the form of tax sharing and grants, to address the vertical and horizontal imbalances is critical for the successful implementation of federalism. Clear functional assignment among all government tiers for revenue raising authorities and bases, and policy guidelines for expenditure management, borrowing by SNGs, and debt management also need to be a part of the fiscal federalism framework. Of the various components of fiscal federalism, DRM is significant as it will make SNGs more independent, accountable, and capable to deliver increased and better public services. There are, however, huge gaps in DRM in SNGs with negligible revenue collection. This could be one of the reform areas that will

50 Footnote 39. The Local Government Operations Act 2017 requires local governments to design and implement an internal control system. A copy of internal audit report needs to be provided to the external auditors at the time of the audit. 
have considerable positive outcomes in development operations, social development, and service delivery. The reform plan should include capacity development on domestic resource and revenue mobilization.

It is also recommended that any policy advisory or technical support in this area (fiscal federalism) is guided by the policy and advisory technical assistance report as it presents a comprehensive analysis of gaps and needs, policy recommendations, as well as implementation strategies on all components of fiscal federalism and overall PFM improvement in SNGs. ${ }^{51}$

Additionally, ADB together with other development partners should have a policy dialogue with the government for adequate and skilled human resources in PFM for SNGs. This is crucial for the operation of effective and efficient PFM systems and to reduce fiduciary and corruption risks.

\section{Procurement}

The Public Procurement Act (PPA), 2007 and the Public Procurement Regulation (PPR), 2007 form the legal framework for procurement in Nepal and are based on international standards. The PPA is applicable to all public procurements with open competitive bidding as the default method of public procurement. The PPA stipulates the establishment of the Public Procurement Monitoring Office (PPMO) and decentralized procurement to ministries, departments and agencies. All public procurement must adhere to the procurement principles of an open, transparent, objective, and competitive procurement and maximum returns of public expenditures. The procurement process was reformed in 2010 with the introduction of e-bidding and multi-year contracting for priority projects. This was further amended in 2015 based on its implementation, but was not considered to be fully compliant with international standards.

PPMO reports directly to the Office of the Prime Minister and Council of Ministers (OPMCM). The procurement function of the government is very well separated into policy (by PPMO), execution (by procuring entities and sector ministries), and independent complaint reviews by a review committee without any conflicting duties and responsibilities, which is in line with international practices. Procuring entities are required to establish a procurement division, section, or unit to carry out procurement activities. While these units have been established in most entities, they are not yet fully internalized nor do they function effectively as a permanent unit of the organization. There are oversight agencies like the Commission for the Investigation of Abuse of Authority ( $\mathrm{CIAA}$ ) and $O A G$ that are constitutional bodies, and the National Vigilance Center under the OPMCM, which examines compliance on procurement processes and carries out technical audits of projects at different stages in the project cycle. Also, there is parliamentary oversight of procurement and public expenditure by the Public Accounts Committee. ${ }^{52}$ Finally, bidding communities and various contractors and consultants' associations like the Federation of Contractors Association of Nepal and the Society of Consulting Architectural and Engineering Firms are key players in the public procurement environment. Other stakeholders include donor organizations like ADB, World Bank, and other bilateral organizations. ${ }^{53}$

51 Footnote 39. While some key legislations have been enacted and the National Natural Resources and Fiscal Commission constituted, subnational governments face challenges in grant utilization and fiscal discipline at large.

52 Responsibilities of these institutions are provided in Table 1 Chapter II: Country Overview.

53 ADB/NRM. 2016. Nepal: Country/sector procurement assessment report, 2015. Nepal. 
Procurement entities should strictly follow the standard procurement documents and guidelines and manuals provided by the PPMO. Procedures for bid submission, receipt, and opening are clearly described in these documents. Procuring entities are also required to prepare an annual procurement plan and a master procurement plan based on the approved program or project and budget. Copies of annual and master procurement plans need to be shared with PPMO.

The PPMO has developed and rolled out a webbased e-GP system (www.bolpatra.gov.np). ${ }^{54}$ It covers the centralized registration of bidders, procurement planning, e-tendering and e-submission, bid evaluation, contract award, contract management, e-payment, and other activities. PPMO has a separate IT Section to develop, execute, and maintain the e-GP system. An e-GP help desk has been established for technical trouble shooting and backstopping support to procuring entities. ${ }^{55}$ The e-GP system has been considered transformative in enhancing efficiency, transparency, accountability, and more importantly in reducing procurement related challenges and risks such as collusion.

PPMO conducts regular training programs on procurement for bidders and government officials. A curriculum on public procurement has also been developed in partnership with Nepal Administrative Staff College and training programs are conducted through the ADB supported Capacity Development Resource Center in Kathmandu as well as in districts for field-based officials and stakeholders. ${ }^{56}$

The PPA defines fraudulent, corrupt and other prohibited practices and sets out a code of conduct for government employees, and individuals or firms involved in procurement operations. Accordingly, procurement and contract documents include these provisions. It also includes provisions for blacklisting firms or individuals that have been convicted. PPMO publishes blacklisted bidders on its website. However, actions taken against those breaching the code of conduct are rare. Also, the Right to Information Act mandates all procuring entities to disclose procurement-related information. PPMO's website and e-GP portals publish relevant data and information including PPA, PPR, and policies governing public procurement. Bidding opportunities and contract awards are also publicly accessible, but government procurement plans are not. ${ }^{57}$

Nepal Public Procurement Strategic Framework (NPPSF) Phase I (FY2010-2013) was a major programmatic initiative of the government in strengthening the country's public procurement system. Following the achievements of NPPSF Phase I, NPPSF II (2013-2016) was implemented, which included capacity building, knowledge transfer, and e-GP system development. ADB's SPMP, with co-financing from DFID and the EU, provided financial and technical assistance to develop the e-GP system. In December 2015, the government decided to roll out the e-GP system to all procuring entities all over the country.

The Country/Sector Procurement Assessment Report (CSPAR) was prepared in 2016 to identify country and sector level strengths and weaknesses, carry out risk assessment, and identify issues that hinder procurement processes and project implementation and suggest mitigation measures. The CSPAR was updated in July 2018 to take stock of progress made and key actions including those arising due to the changed procurement environment. ${ }^{58}$

54 The e-GP system was developed under ADB funded Strengthening Public Management Program.

55 PPMO. 2017. Consolidated Report of Public Procurement Monitoring and Complaints. Nepal.

56 PPMO. 2017. Annual Report of PPMO 2017. Nepal.

57 MOF. 2015. PEFA Assessment: Nepal PFM Performance Assessment II as of FY2014. Nepal.

58 ADB/NRM. 2018. Country/sector procurement assessment report, 2018. Nepal. 
Since CSPAR 2016 and the update in 2018 undertook comprehensive risk assessment in procurement, this assessment only highlights major risks and challenges, largely from an institutional perspective and not a technical perspective. The CSPAR was based on the assessment of 20 indicators derived from the Methodology of Assessment of Procurement System by the Organisation for Economic Co-operation and Development's development assistance committee and the ADB Guide for Assessing Procurement Risk (August 2015), and it covered the four pillars. Each pillar was given a score based on the assessment. The scores range from 0 to 3 for each indicator. ${ }^{59}$ A summary of this assessment for $\mathrm{Nepal}$ is provided in Table 5.
Based on the CSPAR 2016, Nepal's procurement risk is rated "Substantial" and for sectors from "Substantial to Moderate" (on a scale of High, Substantial, Moderate, and Low). The score and risk remain unchanged in the CSPAR 2018 update.

Based on the PEFA of May 2015, the overall assessment on the procurement dimension ( $\mathrm{PI}-19$ ) is $B$ (on a scale of $A, B, C, D$ with $A$ being the best). Table 6 compares scores in 2015 with those in 2006.

Major procurement weaknesses and risks based on the CSPARs 2016 and 2018, PEFA 2015, and 2017 annual reports of CIAA and OAG) include the following under the four pillars:

Table 5: Summary of Country/Sector Procurement Assessment, Nepal (2016)

\begin{tabular}{|c|c|c|c|c|c|c|c|}
\hline Pillars & $\begin{array}{l}\text { Country } \\
\text { Score }\end{array}$ & Maximum & Transport & Agriculture & Education & Energy & $\begin{array}{c}\text { Urban } \\
\text { and Water }\end{array}$ \\
\hline Legislative Framework & 2.0 & 3.0 & 2.3 & 1.87 & 2.0 & 1.95 & 2.2 \\
\hline $\begin{array}{l}\text { Institutional and } \\
\text { Management Capacity }\end{array}$ & 1.8 & 3.0 & 2.0 & 1.5 & 1.38 & 1.91 & 2.04 \\
\hline $\begin{array}{l}\text { Procurement } \\
\text { Operations and } \\
\text { Markets }\end{array}$ & 1.8 & 3.0 & 1.83 & 1.4 & 1.42 & 1.71 & 2.09 \\
\hline $\begin{array}{l}\text { Integrity and } \\
\text { Transparency }\end{array}$ & 1.3 & 3.0 & 1.66 & 0.99 & 1.28 & 1.33 & 1.28 \\
\hline Weighted Average & 1.72 & 3.0 & 1.95 & 1.44 & 1.52 & 1.72 & 1.9 \\
\hline
\end{tabular}

Source: ADB/NRM. 2018. Nepal: An Update of Country/Sector Procurement Assessment Report, Draft Final Report. June 2018. Kathmandu.

Table 6: Nepal PEFA Ratings for Public Procurement

\begin{tabular}{l|c|c|}
\hline Performance Indicators & $\mathbf{2 0 0 6}$ & $\mathbf{2 0 1 5}$ \\
\hline Transparency, comprehensiveness, and competition in the legal and regulatory framework. & C & B \\
Use of competitive procurement methods. & C & D \\
Public access to complete, reliable and timely procurement information. & C & C \\
\hline
\end{tabular}

Source: Government of Nepal, Ministry of Finance. 2015. PEFA Assessment: Nepal PFM Performance Assessment II as of FY 2013-2014 (May 2015). Kathmandu.

59 Score 3 indicates full achievement of standards, 2 indicates less than full achievement, 1 is for areas where substantive work is needed, and 0 indicates failure to meet the standard. 
(a) Pillar I: Legislative and regulatory framework. Although existing procurement laws and regulations are adequate, (i) they are not keeping pace with recent developments, (ii) existing laws and regulations are poorly implemented, (iii) amendments are weakening the existing PPA/PPR instead of strengthening them, (iv) lack of harmonization between PPA/PPR and multinational development banks on certain aspects of bidding (for example, Single Stage-Two Envelope bidding is not allowed in PPA and PPR) (v) lack of guidance notes for sectors and for special circumstances like earthquakes, and (vi) ineffective complaints review mechanism due to high fees for complaint review and multiple jurisdictions for filing complaints.

Absence of a legal framework for public procurement under the federal structure poses a risk. New public procurement acts at all levels need to be formulated in line with the new constitution but this has yet to be done. The federal act needs to be finalized urgently as the SNGs need to align their acts with the federal act. In the absence of a new federal procurement act, PPA and PPR continue to govern all the procurement processes at all levels of government.

(b) Pillar II: Institutional framework and management capacity. There is absence of (i) consolidated procurement plan and inadequate links to budget processes, (ii) funding and resources to train procurement professionals, (iii) follow-up on internal audit recommendations, and (iv) designated cadres for procurement specialists with specified TOR in the public service cadres. The PPMO is weak and lacks adequate human resources and procurement experts, and procurement related database and information management systems. The CIAA also does not have enough experts on procurement matters.

Weak contract management of procuring entities remains a big challenge. Project implementation suffers from time and cost overruns due to poor procurement planning and contract management. Procurement plans are not always prepared as part of the annual work program budgets, and even if prepared, are largely ad hoc without realistic cost estimates and timelines. ${ }^{60}$ According to the PPMO annual report 2017, not a single infrastructure project in Nepal has been completed on time and one of the major causes has been weak contract management.

Some of the issues highlighted by the PPMO annual report 2017 in relation to contract management relate to the (i) quality of performed works not according to the contract, (ii) extension of contract completion deadline without sufficient reasons, (iii) variation orders given even for design and build contracts, (iv) no actions taken even when the jobs were not performed according to the contract, ( $v$ ) poor record keeping of procurement operations, (vi) lack of effective quality assurance mechanisms, and (vii) delayed payments. 
(c) Pillar III: Procurement operations and market practices. (i) Mismatch between the size of contract and capacity of local contracting industry (by bidding beyond capacity, contractors fail to complete projects on time), (ii) lack of interest of foreign firms, (iii) situations of joint ventures where ghost consultants are supervising ghost contractors due to lack of effective participation in project execution by the lead joint venture partner in works and team leaders from the lead consulting firm, leading to delays and nonperformance, (iv) situations of abnormally low bid prices leading to delays, nonperformance, and low quality products (low quality firms bid low just to win the contract and stay in business), ( $v$ ) cost estimates and designs are not based on market research and analysis, (vi) unwarranted slicing of procurement packages to dissuade competition, smaller packages to avoid the open bidding thresholds, using the direct shopping method, and increasing bid sizes to raise the value of the procurement package with the intention to confine competition to targeted contractors. ${ }^{61}$

Operation of the e-GP system is faced with several problems, including weak infrastructure, human resources, and required technical (backstopping) support. While it has been acknowledged that the e-GP system is fundamental in addressing procurement related risks, declining use of the system owing to various technical and enforcement issues has increased those risks.

(d) Pillar IV: Integrity and transparency of the public procurement system. Collusion between bidders and procuring entities is a major risk. ${ }^{62}$ It is claimed that about $51 \%$ of firms in Nepal give gifts to secure government contracts, which is more than twice the regional average. About $88 \%$ of people surveyed think the most important factor in winning procurement contracts is personal connections with government officials or political parties. ${ }^{63}$ There is a lack of effective mechanisms and capacity to deter and detect cartels and collusion, and no specific policy, procedure or framework to govern conflict of interest situations. Actions against cases of fraud and corruption remain weak.

Public procurement reform is included in the Fourteenth Plan (FY2017-2019). This includes strengthening of $\mathrm{PPMO}$, including expansion of the e-GP system. ${ }^{64}$ A budget to undertake the planned reforms is not in the current fiscal year. While the PFMRP II project plans to support procurement reforms, support will not be adequate to address all the institutional reform needs of PPMO and procuring entities. In fact, the reform activity under PFMRP II is only to prepare an action plan for the implementation of a separate Public Procurement Enhancement Project.

The list that follows includes some of the proposed reform priorities to address procurement risks, which can be undertaken

61 PPMO. 2017. Annual Report 2017. Nepal.

62 Footnote 61. Though the Public Procurement Act includes provisions of blacklisting of firms or individuals, these provisions are not effectively implemented.

63 World Bank. 2018. Nepal Systematic Country Diagnostic. Nepal.

64 Government of Nepal, NPC. 2017. Fourteenth Plan (2017-2019). Kathmandu. 
through stand-alone or sector programs and projects or technical assistance. These should be a part of the regular policy dialogues between ADB and the government, as well as among development partners a as part of a coordinated support dialogue.

(a) Fully functional electronic government procurement system. Making the e-GP system fully functional, upgrading it to include all the procurement processes, rolling it out to all procuring entities, including SNGs, with adequate technical backstopping support, and enforcing its use is fundamental to reduce procurement risks, and in increasing efficiency and transparency. ${ }^{65}$ Mandatory use of the system by all procuring entities should be promoted through policy dialogues and investment projects by including a clause in covenants and design and monitoring frameworks. ADB should also support and incentivize government to use the system by providing TA resources to improve the legal and regulatory framework and introducing the required procedural changes to mandate its use. Additional TA resources may also be provided to modify or enhance and upgrade the system in accordance with the federal system of governance and improve the capacity of SNGs.

(b) Institutional strengthening of PPMO. Given the critical importance of the PPMO in monitoring and regulating public procurement and given the increased $A D B$ portfolio in Nepal ( $\$ 2.40$ billion in 2017 from $\$ 1.70$ billion in 2015), institutional strengthening of the PPMO is the key to addressing procurement risks, including mechanisms to detect and deter collusive practices among bidders and procuring entities. Institutional strengthening shall include; (i) amendment of PPA to address the drawbacks for competitive bidding; (ii) development of accredited procurement experts (development of accreditation system); (iii) development of information management system (procurement database) and monitoring framework; (iv) preparation of sectorspecific guidelines in coordination with sector ministries; ( $v$ ) mechanisms to determine a ceiling on bid capacity of contractors and adding this to the PPA/PPR, and making the bid capacity assessment of contractors mandatory before awarding a new contract; and (vi) establishment of proposed Procurement Support Offices at federal level for coordination and at provincial level for technical and advisory support. Training programs on procurement processes, contract management, and e-GP to relevant officials at all government tiers also need to be part of the institutional strengthening plan.

\section{Corruption}

Nepal is ranked 124 out of 180 countries with a score of 31 (100 is the least corrupt) in Transparency International's Corruption Perception Index 2018, which signifies that corruption is endemic in Nepal. ${ }^{66}$ The Bertelsmann Stiftung's Transformation Index (BTI) 2018 reported that misappropriation of public resources and other forms of corruption

65 ADB provided technical and financial support to PPMO to develop the e-GP system through the Strengthening Public Management Program.

66 Transparency International. 2018. The Corruption Perception Index Report 2018. 
are endemic in Nepal. Rules and regulations to ensure transparency exist but are enforced poorly, and anticorruption agencies lack the political or administrative support necessary for working effectively. ${ }^{67}$

Nepal has an official policy of zero tolerance toward corruption. State legal provisions have criminalized corruption and its various forms including bribery, money laundering, and fraud. The Prevention of Corruption Act 2002, the CIAA Act 1992, and their associated rules provide the legal framework for anticorruption. These laws list more than a dozen categories of corrupt acts and prescribe punitive measures through imprisonment or financial penalties. The Prevention of Corruption Act also makes provisions for preventive measures through the establishment of the National Vigilance Centre (NVC) and making a mandatory provision for public servants to declare their assets annually. Other important laws related to anticorruption are the Right to Information Act 2007, Special Court Act 2007, Anti-Money Laundering Act 2008, and Good Governance Act 2008. ${ }^{68}$ Nepal became a signatory to the United Nations Convention Against Corruption in 2011. ${ }^{69}$

The CIAA is the apex constitutional body that investigates corruption by public officials. The Special Court is established to adjudicate cases of corruption. CIAA files corruption cases in Special Court for appropriate punitive actions following an investigation. The National Vigilance Center, established in 2003, is mainly responsible for technical audits of projects to ensure their legal and technical compliance and for the prevention of corruption. The OAG is a constitutional body mandated to audit public offices and public corporations. The parliamentary Public Accounts Committee examines public accounts and the OAG's report to reduce misuse and abuse of public funds. The Department of Revenue Investigation is tasked with controlling revenue leaks and misuse of foreign exchange, and the Anti-Money Laundering Department investigates and prosecutes cases of antimoney laundering and financial crimes. Table 1 provides details of these agencies.

Nepal has three tiers of courts: a supreme court at the federal level, high courts at provincial level, and district courts. The supreme court also has a bench to deal with constitutional issues, including conflicts related to federalism. The special court is a separate bench of the judiciary mandated to effectively and swiftly deal with corruption cases.

Nepal has a vibrant media, with scores of print dailies, weeklies, and monthlies in Nepali as well as English and several ethnic and regional languages. Community radio has also expanded rapidly as an important source of news and information, especially in rural areas. Growing electric grids, complemented by satellite and mobile technology have also fostered a diverse and contentious public sphere in which voices are increasingly heard at all levels.

Media, civil society, and citizen's organizations are agile in Nepal and can constrain the government from becoming autocratic or irresponsible. Nepal ranked 106 (out of 180 countries) on the World Press Freedom Index published by Reporters Without Borders in 2018 with a global score of

67 Bertelsmann Stiftung (BTI). 2018. https://www.bti-project.org/en/reports/country- reports/detail/itc/npl/.

68 These statutes can be accessed from www.lawcommission.gov.np.

69 CIAA. 2014. The Institutional Strategy for 2014-2019 of the CIAA. Kathmandu. http://ciaa.gov.np/images/ publications/1422355208ciaa_institutional_strategy_nepali2014_2019.pdf (in Nepali). The CIAA had strategies for combating corruption in 2002 and 2006. 
32.05 (a lower score means more freedom). ${ }^{70}$ According to the World Bank's Worldwide Governance Indicators, in the last 10 years (2006-2016), improvement has been noted in the categories of voice and accountability, political stability and governance effectiveness, whereas the categories of regulatory capacity, rule of law and control of corruption have been downgraded. ${ }^{71}$ Table 7 provides the percentile rankings in the six categories.

Despite a sound legal framework and political party leaders and government authorities routinely speaking out against corruption, eliminating corruption in Nepal remains an elusive goal. The World Bank Risk and Resilience Assessment Nepal, 2018 stated that Nepal risks a political system ridden with elite capture, political patronage, and corruption resulting in failing technical support for combating corruption as it becomes a more endemic problem. ${ }^{72}$ Some of the major issues are described as follows: (a) Poor implementation and enforcement of rules and regulations. An assessment of the national integrity system in Nepal in 2014 found a worrying gap between law and practice in anticorruption institutions. It also highlighted impunity and indifference in law enforcement agencies contributing to weak implementation of rule of law. ${ }^{73}$ The CIAA annual report 2017 also highlighted failures in abiding by rules and procedures, misappropriation, and malpractice in financial management and public procurement, and increased cases of bribery. ${ }^{74}$ Laws related to conflict of interest are absent.

(b) Weak institutional capacity. Despite the constitutional mandate to punish corrupt practices, oversight institutions have not been effective in reducing corruption, exemplified by Nepal's low ranking in various international

Table 7: Worldwide Governance Indicators, Nepal (2006, 2011, and 2016)

\begin{tabular}{l|c|c|c|c|c|c}
\hline & \multicolumn{7}{|c}{$\begin{array}{c}\text { Indicators } \\
\text { Year }\end{array}$} & $\begin{array}{c}\text { Voice and } \\
\text { Accountability }\end{array}$ & $\begin{array}{c}\text { Political } \\
\text { Stability }\end{array}$ & $\begin{array}{c}\text { Government } \\
\text { Effectiveness }\end{array}$ & $\begin{array}{c}\text { Regulatory } \\
\text { Quality }\end{array}$ & $\begin{array}{c}\text { Rule } \\
\text { of Law }\end{array}$ & $\begin{array}{c}\text { Control } \\
\text { of Corruption }\end{array}$ \\
\cline { 2 - 7 } & \multicolumn{7}{c}{ Percentile Rank } \\
\hline 2006 & 23.1 & 4.3 & 19.5 & 32.3 & 31.6 & 28.8 \\
2011 & 32.4 & 8.1 & 18.0 & 25.1 & 21.1 & 23.2 \\
2016 & 38.9 & 19.1 & 19.7 & 23.6 & 19.7 & 23.6 \\
\hline
\end{tabular}

Source: World Bank Institute. http://info.worldbank.org/governance/wgi/index.aspx\#reports.

70 Reporters Without Borders. 2018. World Press Freedom Index 2018. Paris. https://rsf.org/en.

71 World Bank. 2017. Worldwide Governance Indicators 2017. Washington DC. http://info.worldbank.org/governance/ wgi/index.aspx\#reports.

72 World Bank. 2017. Nepal Risk and Resilience Assessment. https://olc.worldbank.org/system/files/Nepal.pdf.

73 Transparency International Nepal. 2014. The National Integrity System Nepal Report 2014. Nepal.

74 CIAA. 2017. 27th Annual Report of CIAA, 2017. Nepal. 
corruption indices and the poor settlement of corruption cases, for example, the special court settled only $17 \%$ of a total 320 cases in FY2018. ${ }^{75}$

(c) Increased corrupt practices and rising impunity. The 2017 annual reports of the CIAA and OAG highlighted (i) vulnerability and misappropriation in revenue collection, (ii) misappropriation of public budgets, (iii) corruption and bribery in procurement, (iv) use of forged invoices to get payments, (v) use of forged educational certificates for getting public jobs, and (vi) noncompliance with policies and regulations. Lack of political commitment and leadership, negligible departmental and legal actions against those guilty of corruption, and several corruption cases which involve influential politicians and officials remaining uncovered or unpunished have given rise to impunity and reduced the effectiveness or significance of oversight institutions. ${ }^{76}$

(d) Increased costs of doing business in Nepal. Bribery in the form of "facilitation payments" are widespread in the distribution of permits and approvals, public procurement, contract awards, and when registering a business. Endemic corruption has reduced competitiveness and significantly increased the costs of doing business in Nepal. ${ }^{77}$ (e) Corrupt judicial system. The BTI 2018 gave a score of 5 (on a scale of 0-10) for the separation of power, 5 for independence of judiciary, 3 for prosecution of office abuse, and 4 for civil rights. It was reported that a large number of pending cases, undue delays in the implementation of court decisions, and controversial appointments of judges resulting from a lack of transparency and political interference are issues of concern in Nepal's judiciary.

The government implemented its second anticorruption strategy and work plan (2009-2012) to combat corruption, but since then no other strategy or work plan has been prepared. The CIAA is preparing its new strategic plan to be effective from 2020. It is also working on amendments of the Anti-Corruption Act and the CIAA Act to integrate recent good practices on anticorruption. ${ }^{78}$ The Fourteenth Plan (2017-2019) has stipulated revisions to the anticorruption laws to align with UNCAC and other international agreements, identification of areas prone to corruption risks and putting in place effective mechanisms to prevent corrupt practices and technical audits of projects. ${ }^{79}$

While several development partners provided technical assistance to anticorruption agencies in the past, only UNDP has planned for technical assistance in anticorruption. Donors and partners have formed an Integrity and Accountability Working Group to better coordinate the anticorruption agenda, and have joint policy dialogues with the government on instilling anticorruption measures. ${ }^{80}$ political/116690 in the national budget.

Setopati. 2017. Special Court settles only 17 percent of cases in past one and half years. http://setopati.net/

The Asia Foundation. 2014. Impunity and Political Accountability in Nepal. Nepal.

Footnote 67. Rules and regulations to ensure transparency exist but are enforced poorly.

Based upon interviews at CIAA, Kathmandu.

The Integrity and Accountability Working Group was earlier called the Anticorruption Working Group. 
There are several factors that contribute to an enabling environment for corruption to take place. While some were discussed earlier under challenges and risks, there are institutional systems and processes, particularly related to PFM and procurement that support corrupt practices such as the following:

- A weak internal control and PFM system makes it easier to misuse resources.

- Inadequate and ineffective supervision and monitoring by all concerned contributes to poor quality outputs for the same costs; noncompliance; and cases of resource misuse and collusion going unnoticed and unpunished.

- Ineffective; nonuniform; and nontransparent procurement systems facilitate collusive practices among bidders and procuring entities.
By strengthening PFM and procurement systems, the risks in these areas are minimized or mitigated and corruption risks reduced. ADB should therefore focus more on PFM and procurement reforms to address corruption issues. Additionally, it is suggested that ADB include assessments of the quality of products and services, integrity, and value for money in the monitoring of its projects and programs, which will make executing and implementing agencies more responsible and accountable. Capacity building of oversight agencies to detect fraud and collusive practices should also be included in projects, programs and TAs. 


\section{USE OF COUNTRY SYSTEMS}

W ell-performing country systems are essential to ensure that public expenditures for ambitious national plans translate into development results in the most efficient, effective and sustainable manner (World Bank, 2012; ADB, 2014). They set out the regulations, systems, and processes to be followed by officials managing public expenditures in budget execution, financial reporting, auditing, and procurement. Because they determine how governments collect, manage and allocate public resources across different sectors, the quality of country systems has a transversal effect on overall development effectiveness and results. ${ }^{81}$
Assessing the use of the country system requires an overview of ADB's portfolio, which is provided in Appendix 10. The total financing of ADB's assistance program for Nepal in 2018 was $\$ 2,835.76$ million. It comprises 49 loans and grants and projects ( $\$ 2,809.37$ million) and 18 TA projects (\$26.39) currently being implemented in 8 sectors. Additionally, there are 21 projects in the pipeline (2019-2021) and financing for these projects is yet to be confirmed. The share of the loan is $89.12 \%(\$ 2,527.35$ million), the grant is $9.95 \%$ ( $\$ 282.02$ million), and the TA is $0.93 \%$ ( $\$ 26.39$ million) of the total financing (ongoing projects). Table 8 provides the details of sector projects and funding.

Table 8: ADB Nepal Portfolio (Sector Loans and Grants)

\begin{tabular}{|c|c|c|c|c|c|}
\hline \multirow[b]{2}{*}{ Sectors } & \multicolumn{2}{|c|}{ No. of Operations } & \multicolumn{2}{|c|}{$\begin{array}{c}\text { Financing } \\
\text { (ongoing projects only) }\end{array}$} & \multirow[b]{2}{*}{ Total } \\
\hline & Ongoing & Pipeline (2019-2021) & Loan & Grant & \\
\hline Agriculture and Natural Resources & 8 & 7 & 148 & 80 & 228 \\
\hline Education & 5 & 2 & 467.85 & 30 & 497.85 \\
\hline Energy & 8 & 4 & 517.67 & 40 & 557.67 \\
\hline Finance & 1 & 0 & & 5 & 5 \\
\hline ICT & 1 & 0 & & 23.5 & 23.5 \\
\hline Industry and Trade & 1 & 0 & 21.40 & & 21.40 \\
\hline Transport & 13 & 5 & 543.75 & 48.92 & 592.67 \\
\hline Urban and Water & 12 & 3 & 828.66 & 54.60 & 883.26 \\
\hline Total & 49 & 21 & $2,527.35$ & 282.02 & $2,809.37$ \\
\hline
\end{tabular}

ICT = Information and communication technology.

Source: ADB Nepal Resident Mission.

81 Global Partnership for Effective Development Co-operation. 2016. Monitoring Data, Table A.9b. [2/2]. http://www. undp.org/content/undp/en/home/librarypage/development-impact/making-development-co-operation-moreeffective--2016-progress-re.html. 
ADB generally uses country systems in Nepal for the administration of loans and grants but follows its own system for procurement and financial management in terms of TA projects.

Budgeting (fully used): ADB's assistance to Nepal in the form of loans and grants (national and subnational) is fully on-budget, which means loans and grants are included in the government's budget Red Book. The TA projects are off-budget and are not reflected in the Red Book but the details are included in the Statement of Technical and Other Assistance Book (also known as the Blue Book). In FY2016, 63\% of Nepal's foreign assistance (\$678.65 million) was disbursed through on-budget projects and 37\% (\$395.41 million) through off-budget projects. ${ }^{82}$

Treasury (partially used): ADB loans and grants proceeds are reflected in the government's treasury system but since these loans and grants are transferred to special accounts under the government's consolidated fund and managed as agreed between ADB and the government and in accordance with ADB's Loan and Disbursement Handbook, the system is "partially used." Different modes of disbursements are used as agreed and in the project administration manual. These include (i) direct payment to contractors and suppliers by ADB with payment details entered into the government's treasury system after the payment is made ${ }^{83}$ (ii) an advance (imprest) account, which is opened in the central bank and managed by the concerned project implementing unit and used for smaller payments. ADB's statement of expenditure method is used for reimbursement of eligible expenditures and liquidation of advances to the imprest account; and (iii) a commitment procedure for some projects that includes imports of certain goods. ${ }^{84}$ Of the $63 \%$ (\$678.65 million) of Nepal's on-budget foreign assistance, 74\% (\$498.94 million) was channeled through the national treasury system (on-treasury) and 26\% (\$179.72 million) was off-treasury. ${ }^{85}$

Accounting and reporting (partially used): ADB project accounting follows the government's laws and regulations and uses the existing account codes, but $\mathrm{ADB}$ requires implementing agencies to maintain separate project accounts and records by funding sources for all expenditures. ADB requires project financial statements to be prepared in accordance with international accounting principles and practices. For reporting, ADB uses the Government of Nepal's financial reporting system through the Financial Comptroller General's Office but requires the implementing agencies to use ADB report formats.

Audit (fully used): The financial statements of ADB funded projects are audited by OAG in accordance with its rules for foreignfunded projects. ADB keeps the right of thirdparty external audit in circumstantial cases. For projects implemented by state-owned enterprises (e.g., Nepal Electricity Authority, Kathmandu Valley Water Supply), project statements are audited by private auditing firms hired by the OAG. These private firms report to the OAG. The audit observations of the concerned agencies are then provided by the OAG.

82 MOF. 2016. Development Cooperation Report. http://www.mof.gov.np/uploads/document/file/ DCR__20171231102231.pdf.

83 ADB views direct payments to contractors and consultants as consistent with commercial banking practices and hence not a departure from country systems. ADB.2014.op.cit., p.15, GACAP II Guideline.

84 ADB provides a commitment letter to the beneficiary's bank for the payment of its share in the project (e.g., 80\% ADB's share and $20 \%$ government's share).

85 Footnote 81. The volume of foreign aid disbursement in Nepal in FY2016 reached a total of \$1,242.45 million. 
Procurement (partially used): ADB uses country systems for national competitive bidding for procurement of goods and services under specified thresholds. For procurement above the specified thresholds, an international competitive bidding process is used and ADB guidelines apply.

According to the Global Partnership for Effective Development Cooperation report 2016,11 countries (18\%) made progress in strengthening their country systems, and Nepal was one of those. The overall use of country systems in Nepal in budget execution was $68.8 \%$, which was higher than the average of $52.7 \%$ (among 40 participating countries). It was $69.7 \%$ for financial reporting, which is also higher than the average of $55.2 \%$, and $69.7 \%$ for auditing, which was higher than the average $55.5 \% .{ }^{86}$ While ADB has been using Nepal's PFM system substantially ("fully used" for two PFM elements and "partially used" for the other two), the Global Partnership report provides increased confidence to further expand the use of Nepal's country systems in PFM.

There are, however, systemic issues that need to be addressed before further advancements in the use of country systems in PFM can be made. These include (i) fully aligning Nepal Public Sector Accounting Standards with International Public Sector Accounting Standards in financial recording and reporting; one of the major constraints in the alignment is the full digitization of the
PFM system that is integrated with other data management systems and could be operated by multiple users; (ii) low institutional capacity of subnational governments. The PFM system is yet to be fully established, digitized, and made functional in these governments. Project financial recording and reporting by subnational governments will hence be a challenge. Strategic interventions through policy reforms and technical assistance need to be provided to central and subnational governments to improve the overall PFM system in Nepal; only then can ADB anticipate using country systems fully in PFM.

The Global Partnership report shows the overall use of country systems in procurement in Nepal is only $42.6 \%$. This is higher than the average of $37 \%$. Full use of country systems will require significant reforms, including (i) institutional strengthening of Public Procurement Monitoring Office (PPMO), an advisory and oversight agency for public procurement; (ii) upgrading and operationalizing the e-government procurement system with provisions for adequate technical support; (iii) revision of Nepal's Public Procurement Act to make public procurement more competitive and include international policies and practices; and (iv) strengthening oversight agencies. Until these reforms are undertaken, ADB should continue the current approach of using the country system for national competitive bidding and ADB's system for international competitive bidding.

86 Footnote 81. The Global Partnership monitoring report highlighted that strong institutionalized partnerships at the country level can build mutual trust and underpin transparency and accountability. 


\section{GOVERNANCE \\ AND INSTITUTIONAL \\ CHALLENGES AND RISKS IN SECTORS}

$\mathrm{T}$ his analysis of governance challenges and risks in the sectors where ADB Nepal has operations complements sector assessments. ${ }^{87}$ The sector assessment provides an overview of the sector, the government's strategy, ADB's experience and lessons learned, engagement of development partners in the sector, and proposed ADB assistance. This analysis focuses on legal and institutional frameworks, public financial management risks and challenges in the sector, procurement risks, corruption risks, and reform priorities to address the identified risks and challenges.

\section{A. Agriculture and Natural Resources Sector}

\section{Legal and Institutional Framework}

The federal constitution of Nepal has functionally assigned state responsibilities for the agriculture and natural resources (ANR) sector to all three levels of government. The larger field responsibilities for four subsectors of ANR, agriculture, forestry and environment conservation, rural development, and, irrigation. are mostly assigned to the local level but medium and larger level programs and policy matters are under provincial and federal spheres respectively.

The acts which provide the legal framework to the sector are:

- Water Resources Act (1992)

- Land Act (1967)

- Forest Act (1993)
- Soil and Water Conservation Act

- Environment Protection Act (1997)

- Food Act (1996)

- Pesticide Act (1991)

- Nepal Agricultural research Council Act (1992)

- Mines and Mineral Act (1993)

- CITES Act (2017)

There are several policies related to the ANR sector, such as:

- Land Use Policy (2015)

- Agriculture Policy (2004)

- Irrigation Policy (2003)

- Fertilizer Policy (2002)

- Forestry Sector Policy (2000)

- Leasehold Forest Policy (2002)

- Biodiversity Strategy (2002)

The government has formulated an Agriculture Development Strategy (2015-2035) as a 20-year vision for agriculture development to accelerate agricultural growth through four strategic components related to commercialization, productivity, competitiveness and governance while promoting inclusiveness and sustainability.

The policy environment in the sector, particularly in the agriculture subsector is weak. In the absence of an agriculture act, the commercial regulatory environment for cooperative farming, contract farming, leasing, public-private partnerships, and access to agricultural finance is lacking.

87 ADB. 2018. Sector Assessments (Summary): Country Partnership Strategy Nepal (2020-2024). Manila. 
The federal Ministry of Agriculture and Livestock Development (MOALD) was created by merging the former ministries of Agriculture Development and Livestock and Aviaries. The ANR sector is the responsibility of several ministries as listed in Table 9.

The provincial governments have ministries for agriculture and infrastructure that have been formed by merging relevant sector agencies (agriculture extension, livestock, rural infrastructure, and small irrigation) at the regional and district levels, which were established under the previous governance structure. Similarly, former local and field offices have been handed over to the respective local governments.

Institutional issues and challenges as highlighted in the Agriculture Development Strategy are (i) lack of coordination, (ii) poor attention to social and geographic inclusiveness, (iii) low attention to land management issues, (iv) inadequate consideration for regional trade,( $v$ ) frequent changes in leadership positions, (vi) low budgetary support, (vii) a huge gap between policy formulation and implementation, and (viii) poor monitoring and evaluation.

The sector also suffers from the weak institutional capacity, which has negatively affected planning, budgeting, project design and implementation, undertaking procurement processes, contract management, and financial management. Poor coordination has caused duplication and waste of resources. For example, the Livestock Services Department at the end of the FY2016 provided funds to one program which was already being supported by the Directorate of Livestock Market Promotion. ${ }^{88}$

Institutional arrangements and authorities have changed under the new federal structure. As functional assignments among the three government tiers are yet to be fully clarified, there are overlapping functions in several areas causing confusion and conflicts. The current transition could delay implementation.

\section{Public financial management}

The national PFM system covers all sectors, so country-level assessment of PFM holds true for the ANR sector as well. Only some sectorrelated PFM issues are discussed here.

The former Ministry of Agriculture formulated an Internal Management Control Procedural System 2016 under the Financial Procedure Regulation, 2007. It describes functions of each unit, work processes, exchange of information, monitoring and evaluation, and environment of control and risks. ${ }^{89}$ However, the procedural

Table 9: Responsible Ministries (Federal) for Agriculture and Natural Resources Subsectors

\begin{tabular}{l|l}
\hline Subsectors & \multicolumn{1}{c}{ Responsible Ministries (Federal) } \\
\hline $\begin{array}{l}\text { Agriculture } \\
\text { Agricultural lands and cooperatives }\end{array}$ & Ministry of Agriculture and Livestock Development \\
Forestry and environment conservation & Ministry of Forests and Environment \\
Rural development & Ministry of Federal Affairs and General Administration \\
Irrigation & Ministry of Energy, Water Resources and Irrigation \\
\hline
\end{tabular}

Source: Government of Nepal Allocation of Business Rules 2018.

88 Footnote 41. Underutilization of budget due to weak institutional capacity, particularly at the subnational government level, has affected timely completion of projects.

89 Government of Nepal, Ministry of Agriculture and Livestock Development. 2016. Internal Management Control Procedural System 2016. Kathmandu. 
system has not been updated in accordance with the amendments in the prevailing laws such as amendments to the PPA and PPR in 2016.

Some challenges in PFM are as follows:

(a) Poor links between budget and sector plans. Budget allocation and expenses of the last three fiscal years in the ANR sector show a trend to high levels of virements in capital expenses and unspent budget amounts. The budget variance in FY2015, 2016 and 2017 are $8.6 \%, 12.2 \%$ and $15.1 \%$ of the original capital budget. ${ }^{90}$ The OAG 2018 report found that budgets were appropriated for projects without feasibility studies.

(b) Ineffective financial management and weak spending capacity of implementing agencies. These have resulted in significant implementation delays and underuse of loans and grants. Even national pride projects have been delayed as a result of poor capital expenditures. For example, the Babai irrigation project was started in 1998 and its progress to date is only $49 \%$. Capital expenditures in the sector have remained low: $84.1 \%$ in $2015,81.1 \%$ in 2016, and $85.2 \%$ in $2017 .{ }^{91}$ Allocated resources are not effectively used due to a weak focus on results and poor targeting of beneficiaries. ${ }^{92}$

\section{Procurement}

The national procurement system covers all sectors, therefore country-level assessments of procurement holds true also for the ANR sector. Only some sector-specific challenges and risks in procurement are summarized below.

(a) Weak compliance with rules and regulations. For example, instead of using the approved construction norms, the Department of Irrigation used an illegitimate norm approved by the Director General, which was higher and which created an additional financial burden to the government. ${ }^{93}$

(b) Due to poor project preparedness, procurement contracts are not implemented effectively. Contract administration and management is poor. Contractors do not meet their contractual obligations. Sector agencies accept low quality products without seeking enough quality tests. Administrative and legal actions against contractors, as guided by the contract, are hardly ever taken. Liquidated damage is not yet applied in any contract packages. Management response to issues and implementation of corrective measures is weak. ${ }^{94}$

Due to weak project design, a significant number of variations are made in the contracts.

\section{Vulnerability to corruption}

The national system for combating corruption covers all sectors, therefore country-level assessments hold true also for ANR sector assessment. Only some sector-specific issues are discussed here.

90 Government of Nepal, FCGO. 2017. Financial Statistics. FY 2015, 2016, and 2017. Kathmandu.

91 Government of Nepal, FCGO. 2017. Consolidated Financial Statements FY 2015, 2016, and 2017. Kathmandu.

92 Footnote 41. The Ministry of Agriculture and Livestock Development also provides program-based grants to government and nongovernment organizations and insurance companies, such as Salt Trading Corporation, National Seed Company Limited, and Agro Enterprise Center. This constitutes nearly $75 \%$ of the total budget. However, monitoring of these grants by the ministry has remained weak.

93 Footnote 40. Standards and norms of construction works exist in the irrigation sector, as approved by the Council of Ministers.

94 Aide-mémoires of the review missions. 
ANR receives the highest number of complaints on substandard quality of works and misuse of public funds. Some cases of corruption and irregularities in the sector highlighted by the 2017 annual reports of CIAA and OAG are as follows:

(a) Forgery. Forged documents used by local governments (e.g., forged names of farmers to distribute compensation), forged payments to user committees and staff (e.g., overpayments to staff based on forged travel documents).

(b) Misappropriation of funds. Expenses made without procurement, double payments, unrelated expense claims approved, high prices paid, consultant expenses not audited.

(c) Procurement rules and norms not followed. For example, direct purchases in violation of procurement law and unrealistic cost estimates.

(d) Corruption through (i) cost and time overruns, (ii) not undertaking quality testing of construction materials, and (iii) poor quality products.

\section{Reform priorities in the agriculture and natural resources sector and recommendations to $\mathrm{ADB}$}

(a) Institutional assessment and strengthening of executing and implementing agencies of all government tiers. Given the changed institutional arrangements under the new federal structure, it is recommended that institutional assessment of the sector is undertaken so that appropriate rearrangements are made for ongoing projects. Institutional assessment (from the perspective of federalism as well as overall capacity gaps) should be made mandatory for new projects, and appropriate technical and policy advisory support for institutional strengthening and capacity development are included in projects and programs. A database of assets should be prepared and asset management systems in the sector need to be established with clear functional responsibilities of federal, provincial, and local governments for operation and maintenance.

(b) Enhanced public financial management system and capacity. The PFM system needs to be enhanced and staff capacity improved. Full automation of the PFM system enhances efficiency, transparency, and accountability and should be advocated and possibly supported through projects and programs.

(c) Policy dialogues and missions. Public financial management, procurement, and corruption-related issues should be regularly raised and discussed through policy dialogues and review missions to dissuade misappropriation of funds, misprocurement, noncompliance to rules and regulations, and corrupt practices.

(d) Reform measures included in project and program documents. Sector plans and project documents (e.g., project design and monitoring frameworks under outputs/indicators, covenants, and policy actions for sector development projects) should include public financial management, procurement, and anticorruption reform measures so that issues and risks are effectively addressed and mitigated and reforms are achieved. This will eventually lead to increased efficiency, effectiveness and accountability in the sector and timely achievement of project outcomes. ADB officials responsible for the sector and public 
management experts should work together to integrate reform measures in projects and programs to effectively address these risks.

(e) Digital system and training. The use of the e-GP system needs to be emphasized and training on procurement and contract management needs to be provided to all relevant officials of all government tiers in the sector. ${ }^{95}$

\section{B. Education}

\section{Legal and institutional framework}

The federal constitution of Nepal has assigned education responsibilities of the state to all three levels of governments. School sector duties are mostly assigned to the local level but education as a sector is in the concurrent list for all three levels. Table 10 provides functional assignments of the three government tiers.

Table 10: Functional Assignments Under Federal Context in the Education Sector

\begin{tabular}{|c|c|c|}
\hline Federal Government & Provincial Government & Local Government \\
\hline $\begin{array}{l}\text { Education national policy, laws, and } \\
\text { parameters, national education plans } \\
\text { Coordination with development } \\
\text { partners }\end{array}$ & $\begin{array}{l}\text { Provincial education policy, } \\
\text { laws, standards, regulation, } \\
\text { provincial plans } \\
\text { Provincial academic } \\
\text { research; educational } \\
\text { information management }\end{array}$ & $\begin{array}{l}\text { ECD, school education, nonformal } \\
\text { education, special education } \\
\text { policies, laws, standards, planning, } \\
\text { implementation and regulation, } \\
\text { secondary education coordination and } \\
\text { regulation }\end{array}$ \\
\hline $\begin{array}{l}\text { National school curriculum framework, } \\
\text { core content and regulation }\end{array}$ & $\begin{array}{l}\text { Provincial curriculum, } \\
\text { textbook production }\end{array}$ & $\begin{array}{l}\text { Curriculum (local content) and } \\
\text { textbook distribution }\end{array}$ \\
\hline $\begin{array}{l}\text { TVET national policy, curriculum } \\
\text { framework, accreditation and skill } \\
\text { testing framework and regulation }\end{array}$ & $\begin{array}{l}\text { TVET provincial policy, } \\
\text { curriculum, regulation }\end{array}$ & $\begin{array}{l}\text { TVET planning, operation, licensing, } \\
\text { and regulation }\end{array}$ \\
\hline $\begin{array}{l}\text { School teachers: service conditions, } \\
\text { testing and regulation }\end{array}$ & $\begin{array}{l}\text { School teacher management, } \\
\text { provincial service conditions, } \\
\text { standards, regulation }\end{array}$ & $\begin{array}{l}\text { School teachers and other staff } \\
\text { management }\end{array}$ \\
\hline School operation national standards & - & $\begin{array}{l}\text { School mapping, licensing, regulation, } \\
\text { school infrastructure, and management }\end{array}$ \\
\hline $\begin{array}{l}\text { School examinations: national } \\
\text { standards and norms; Grade } 7 \text { exams }\end{array}$ & Grade 10 exams & $\begin{array}{l}\text { Grade } 8 \text { exams, student learning } \\
\text { achievements }\end{array}$ \\
\hline Scholarships: national parameters & $\begin{array}{l}\text { Scholarship management for } \\
\text { higher education and TVET }\end{array}$ & $\begin{array}{l}\text { Students' incentives and scholarship } \\
\text { management (school level) }\end{array}$ \\
\hline \multirow{2}{*}{$\begin{array}{l}\text { Central Universities, academies, higher } \\
\text { education: accreditation, standards, } \\
\text { foreign affiliation, central libraries }\end{array}$} & $\begin{array}{l}\text { Provincial higher education } \\
\text { policy, laws, regulations }\end{array}$ & \multirow[t]{2}{*}{$\begin{array}{l}\text { Local libraries, local knowledge, and } \\
\text { skills promotion }\end{array}$} \\
\hline & $\begin{array}{l}\text { Provincial universities, } \\
\text { education consultancies, } \\
\text { provincial libraries }\end{array}$ & \\
\hline
\end{tabular}

ECD = early childhood development, TVET = technical and vocational education and training.

Sources: Government of Nepal, Nepal Law Commission. 2015. The Constitution of Nepal. Kathmandu; Government of Nepal, Office of the Prime Minister and Council of Ministers. 2017. The Unbundling Report. Kathmandu. https:// www.opmcm.gov.np/federalism-admin/; Government of Nepal, Office of the Prime Minister and Council of Ministers. 2018. Government of Nepal Allocation of Business Rules. Kathmandu. https://www.opmcm.gov.np/ download/नेपाल-सरकार-कार्य-वभिजन/?wpdmdl=4188; and decisions by the Cabinet made public as posted on the website of the Office of the Prime Minister and Council of Ministers.

95 Policy and technical support and advocacy to make e-GP fully functional and universally used for public procurement will need to be pursued separately. 
Under the new system of federal government, the Ministry of Education has been expanded to include the functions of the former Ministry of Science and Technology. The federal departments, centers, and allied agencies are being restructured. The Department of Education, National Center for Education Development, and Non-Formal Education Center have been merged into a single Education and Human Resource Development Center. Authority over most functions associated with basic and primary education service delivery has been devolved to 753 local governments. The management of examinations at the end of Grade 10 is the responsibility of provincial governments. The role of MOEST has also shifted from focusing on policy and regulation to monitoring sector developments, providing guidelines and tools for training, and supervising local governments. MOEST no longer has direct control over planning and management of basic and primary education. ${ }^{96}$ At the provincial level, the Ministry of Social Development is responsible for education. The regional education directorates, regional training centers and district units of the National Examination Board have been brought under the provincial governments.

Nepal's constitution provides for compulsory and free school education. Nepal's school education subsector (where ADB is providing support) is governed by the Education Act, 1971 with the Ninth Amendment in October 2017. This act covers early childhood education to secondary education up to Grade 12. It is a central act and is being transformed into a federal education law which will provide the national framework for school education and standards. The provinces are yet to come up with laws on education. Under the new federal context, local governments have the most responsibilities for school management.
The Local Government Operation Act 2017 has given 23 mandates to local governments in the education sector. ${ }^{97}$

One of the biggest risks in the sector under the federal context is poor education service delivery, particularly at the local government level. Regarding the skills development subsector, issues of fraudulent reporting by service providers, nontransparent beneficiary selection processes, misprocurement, weak monitoring of training programs, negligible social marketing of training opportunities and facilities, including post-training support and scholarship, and no mechanism for handling grievances or complaints have led to misuse of funds, high fiduciary risks, ineffective programs, and poor quality outputs and outcomes. ${ }^{98}$

Challenges that contribute to these risks are as follows:

(a) Weak institutional capacity of local governments to execute all the responsibilities assigned to them. The dissolution of functioning district education offices before setting up appropriate institutional arrangements under local governments has hindered smooth operation of education services in several local governments. These governments also do not have adequate technical or administrative staff to effectively manage school operations.

(b) Legal gaps. The formulation and approval of sector acts, policies, and regulations at all government tiers have yet to be completed. Federal acts are the most urgent as provincial and local governments need to align their acts with federal acts. Although the existing Education Act

96 ADB. 2018. Federal System and Changes in Risk Assessment of School Sector Development Program. Manila.

97 Government of Nepal, Nepal Law Commission. 2017. Local Government Operation Act. Kathmandu.

98 ADB. 2016. Fiduciary review of Skills development Project. Manila. 
of 2017 (Ninth Amendment) and regulations prevail until the federal Education Act is approved, local governments seem not to have followed existing acts and regulations. Some local governments legislated and executed their education acts which conflict with the National Education Act 1971. For example, some have started recruiting school teachers based on the terms and conditions they themselves defined. Some local governments have transferred teachers to schools in their areas from schools in other local governments and others have changed the procedures for appointing school management committees. ${ }^{99}$

Concerted efforts are needed to facilitate local governments in the preparation of their education acts and regulations. Failure in the timely instituting of a regulatory environment in the education sector could result in difficulty in regulating education activities of provincial and local governments later on as they are autonomous governments.

(c) Absence of clear demarcation of roles and coordination mechanisms. There are overlapping roles and authorities among government tiers, particularly concurrent functions, which have created confusion and complications in delivery of this important public service. For example, the human resource management and development and maintenance of relevant education statistics is the responsibility of all levels of government. MOEST has provided responsibility for 21 functions of education to education development and coordination units. Both education development and coordination units and local governments have responsibilities for school education at the local level. Without a clear understanding of the roles and authority of all concerned and effective mechanisms for coordination among these governments, service delivery will be negatively affected.

\section{Public financial management}

ADB undertook a fiduciary risk assessment of the ADB funded School Sector Development Program in July 2018. The findings suggested that the risk rating is overall higher as the changes to a federal system of government has created new challenges. ${ }^{100}$

Inadequate allocation of financial resources, fiscal indiscipline, and inefficient expenditures leading to poor service delivery and high fiduciary risks are the main PFM risks in the sector. Causes for these risks are briefly discussed below.

(a) Poor public financial management in local governments. A major share of the education budget will be planned and executed by local governments but they do not have the tools or the capacity to prepare education sector plans, which is important to analyze sustainability of investments as they do not have a rolling plan or forward budgeting systems in place. Many local governments lack internal audit units and for those who have one, there are no unified standards or guidelines for performing these functions. There is also a lack of procedures to ensure segregation of duties between the units within a local government that requests a payment,

99 ADB. 2018. Federal System and Changes in Risk Assessment of School Sector Development Program. Manila.

100 Footnote 99. Apart from development activities (e.g., construction, training), resources for all other activities (e.g., teachers' salaries, text books, scholarship distribution) are now managed by local governments. Budget planning, expenditure management, accounting, and internal audit functions have also been devolved to local governments. 
those who execute the payment and those who account for it. Added to this are human resource capacity constraints and incomplete rollout of a uniform and ICT-based financial management system, a challenge already identified with the 77 District Education Offices, now spread out to 753 local governments. Many local governments have limited capacity and training on financial management as was the case for District Education Offices.

Conditional grant transfers are recorded in single budget line items covering grants for all sectors. Thus, there is no mechanism to review budget execution for each of the intervention areas and budget heads. Grants are provided to schools based on MOEST issued program implementation guidelines, but the expenditure is not reported or reflected in the financial management system. In the absence of a country wide system for capturing details of disbursements to and from each local government and disbursements made by them to schools, fiduciary risk has increased.

(b) Fiscal indiscipline. The OAG 2018 annual report pointed out irregularities in financial management. For example, payments made without supporting documents, funds not released on time, additional advance payments before settling previous advances, excess payments, and payments without deducting taxes. The report highlighted that the grants provided to various academic institutions and projects are not accounted for and no progress reports are prepared. ${ }^{101}$ The NVC's 2017 report highlighted misuse of school funds, accumulated advance arrears, and lack of implementation of accountability mechanisms (public audit, social audit). ${ }^{102}$

(c) Weak links between policy targets, plans, and budgets. The respective local governments have the authority to plan and budget for education as one among several mandated responsibilities i.e., resources for education will compete with other priorities as determined by local governments. Moreover, local governments are not able to develop medium-term education plans to guide the preparation of annual education budgets and yearly operational plans. Absence of a systematic approach to guide the preparation of yearly operational plans and budgets could result in local governments implementing ad hoc interventions in the education sector without necessarily improving learning outcomes for students. For example, in the current fiscal year, investments in several local governments were made to install CCTV cameras in schools. Such ad hoc spending leads to a greater risk of inefficient spending and unsustainable investment in the school education subsector. ${ }^{103}$

(d) Fiscal transfers. Fiscal transfers to subnational governments are constitutionally mandated. According to the present arrangement, local governments have the responsibility of distributing recurrent conditional

101 Footnote 40. Of NPR89.12 billion ( $\$ 891.18$ million) provided by the Department of Education for its subordinate offices in FY2016, authorization of NPR2.51 billion ( $\$ 25.12$ million) was provided only in the last month of the FY.

102 Governmen of Nepal, National Vigilance Center. 2017. Annual Report 2017. Kathmandu.

103 ADB. 2018. Federal System and Changes in Risk Assessment of School Sector Development Program. Manila. 
grants to schools for teacher salaries, scholarships, and textbooks. As MOEST can only influence local governments by instituting required regulatory provisions and incentivizing them by designing conditional grants to be transferred to them for achieving desired outcomes in education, it will require a change in design of the current conditional grant allocation based on a combination of needs and performance of local governments. However, this requires a program and financial monitoring system that can capture information on performance education management information system and how grants were actually spent, i.e., the extent to which they were actually transferred to schools and credible information on how they were used but this is not the case. ${ }^{104}$

\section{Procurement}

In terms of procurement, the devolution of budget, spending, accounting and internal control and audit functions to 753 local governments poses a major increase in fiduciary risk as compared to a centrally controlled system with the Ministry of Education and subordinated district education offices.

(a) Poor capacity for procurement functions, particularly at the subnational level. The capacity constraint has increased substantially by transfer of the functions from 77 district education offices to 753 new local governments despite having staff seconded from those offices. There are inadequate and skilled human resources to undertake procurement processes. Procurement procedures and practices vary among local governments as it is assumed it falls under their authority to develop their own procedures.

There is also a lack of sector-specific procurement guidelines and capacity for local governments to execute them.

(b) Noncompliance and weak contract management. The PPMO 2017 report indicated noncompliance to PPA/PPR. For example, quotations from at least three suppliers for direct procurement are not obtained, recording of each procurement operation is not done, and post-delivery inspection reports are not prepared. Bid packages were sliced or repackaged to support pre-identified bidders, which limited competition. ${ }^{105}$ Due to inadequate technical staff, inspection, supervision, and quality control of civil works have been weak in local governments. Also, blanket grants are provided which do not reflect the true cost of construction. The NVC's 2017 report noted delays in completion of civil works and school construction, inadequate quality assurance in works and goods contracts, and delayed decision making in procurement processes and contract administration. ADB supported a skills development program that reportedly has not been following proper competitive bidding or cost estimate practices. ${ }^{106}$

104 Footnote 103. Since the fiscal transfer of conditional grants to local governments are done on an aggregate single head (26612), local governments' allocation to education is not fully known and captured.

105 PPMO. 2017. Consolidated Report of Public Procurement Monitoring and Complaints. Nepal.

106 Footnote 41. Several training providers (privately owned institutes) have been contracted under the program. 


\section{Vulnerability to corruption}

The CIAA annual report 2017 recorded the largest number of corruption cases in the education sector. Most were (i) forged education certificates used to get jobs in education services; (ii) misappropriation of government grants by public schools and scholarship funds; (iii) use of forged papers and forged programs to get payments; (iv) misappropriation of funds in the construction of school buildings; ( $v$ ) abuse of resources through false data (e.g., increasing number of students to receive more grants, expenses and/or grants claimed for schools that are no longer operational, payments to teachers that do not work, ghost students, teachers, and schools); (vi) breach of confidentiality in the examination system; and (vii) noncompliance of norms for the accreditation and affiliation of educational institutions.

The OAG 2018 report also observed that scholarship funds are misappropriated and poorly monitored, and performance of schools, resource centers and district education offices are weak. Performance audits undertaken by the OAG in selected education institutions also showed poor sector performance and poor compliance with statutory norms. For example, fraudulent practices by service providers were reported in ADB-financed skills development projects. ${ }^{107}$ The Public Expenditure Tracking Study pointed out that the education management information system overstated student attendance and students eligible for scholarships. ${ }^{108}$

\section{Reform priorities in education sector and recommendations to ADB}

Proposed reform measures to address governance risks in the sector are as follows:

(a) Institutional rearrangements to suit the federal context. The education sector is the most affected in terms of changes to the federal structure. The devolution of functions has brought new institutional challenges to efficient execution under the current institutional arrangements and in the lack of adequate resources (financial and human) and capacities of local governments.

(i) Institutional assessment of local governments in relation to the gaps in policies, systems, capacities (finance, technical, human), and mechanisms for service delivery would be useful to formulate appropriate policies, regulations, and guidelines, which are crucial for the smooth devolution and execution of sectoral functions by local governments.

(ii) Roles, responsibilities, and authorities of the three government tiers, particularly related to the concurrent functions, and coordination mechanisms among the three government tiers need to be clearly defined. ADB, along with other development partners, should have policy dialogues with the government to take swift action on this.

107 Footnote 40. Information on the basis for the cost estimate for one of the short-term trainings under the skills development project was south by OAG; but the project could not furnish that information.

108 World Bank. 2014. Public Expenditure Tracking and Quantitative Service Delivery Surveys in Nepal's Education Sector. Kathmandu. 
(iii) Resource planning and management is one important area that needs to be promptly enhanced.

(b) A public financial management reform plan. Given the high fiduciary and corruption risks in the education sector, a PFM reform plan needs to be developed and implemented. This should be supported through investment programs and projects, TAs, and policy dialogues with the government bilaterally and jointly with other development partners. Some proposed reform activities are as follows:

(i) An appropriate PFM system with an effective internal control mechanism is critical to ensure that resources reach the targeted beneficiaries and contribute to achieving sectoral objectives. The PFM system should be information and communication technology-based and uniform across all local governments as this would support proper accounting, reporting, and monitoring of education budgets and grants, thereby reducing fiduciary risks.

(ii) Standard operating manuals and guidelines in PFM need to be developed for local governments.

(iii) Orientation on using the PFM system and training programs on PFM need to be organized for all local governments.

(iv) A performance-based grant system with indicators and targets to assess their achievements needs to be developed. (v) Standard and uniform criteria for allocation of conditional grants to schools should be developed and enforced.

(c) Procurement guidelines specific to the education sector should be prepared. Roles and responsibilities among all the relevant entities at all government tiers, and procedures for procurement also need to be clarified. These could be supported either through $A D B$ investment programs, projects, and TAs, and a policy dialogue with the government to undertake these using its own resources.

\section{Energy}

\section{Legal and institutional framework}

The federal constitution of Nepal has assigned energy sector responsibilities of the state to all three levels of governments. Conservation of water sources, multidimensional use of water, setting parameters, issues related to international and inter-provincial transmission lines, atomic power, and large electricity generation projects are exclusive functions assigned to the federal level. Medium to smallscale generation plants and allied functions such as regulation of services are assigned to provincial and local governments under their exclusive and concurrent lists. ${ }^{109}$ Table 11 provides details of functional assignments among the three government tiers.

Since the sector assessment adequately covers the legal framework, including government strategies in the sector, this is not repeated under this assessment. However, in terms of the challenges, formulation of acts and policies by all government tiers to execute their assigned 
functions are yet to be undertaken, which has created a legal void in the sector and there is a risk that this will affect project implementation.

The federal Ministry of Energy, Water Resources and Irrigation (MOEWRI) was created by merging the former Ministries of Energy and Irrigation and retaining the earlier structure. The ministry's primary responsibilities include (i) formulating legislation; policies and standards related to water resources, energy, and irrigation; (ii) construction of energy infrastructure; (iii) sector coordination; (iv) execution of federal and inter-provincial multipurpose projects; ( $v$ ) national, regional, and international transmission lines, energy trade, and international agreements on water resources; (vi) energy tariff and service standards; and (vii) renewable and alternative energy, investments in electricity development. ${ }^{110}$

\section{Table 11: Functional Assignments in the Energy Sector}

\begin{tabular}{|c|c|c|}
\hline Federal Government & Provincial Government & Local Government \\
\hline $\begin{array}{l}\text { Policy on sustainable development of water resources, } \\
\text { water allocation, management and conservation; } \\
\text { design and standards, framework plans for river basin } \\
\text { and water use. }\end{array}$ & $\begin{array}{l}\text { Provincial electricity policy, laws, } \\
\text { standards, planning, implementation } \\
\text { and regulation; provincial policies and } \\
\text { project implementation on river basins } \\
\text { based on federal policies. }\end{array}$ & $\begin{array}{l}\text { Small hydropower projects } \\
\text { policy, framework, planning, } \\
\text { project implementation and } \\
\text { regulation. }\end{array}$ \\
\hline $\begin{array}{l}\text { Research and development of water resources, } \\
\text { technology and capacity building; international } \\
\text { agreements in water use; climate change, adaptation, } \\
\text { disaster reduction, infrastructure development policy } \\
\text { and laws; determination of major rivers water flow, } \\
\text { allied framework and law, regulation; watershed } \\
\text { management and conservation policy and regulation. }\end{array}$ & $\begin{array}{l}\text { Provincial electricity master plans, } \\
\text { project scrutiny, feasibility studies, } \\
\text { construction, operation and } \\
\text { management. }\end{array}$ & \\
\hline $\begin{array}{l}\text { Investment plans and joint investment policy for } \\
\text { water use among the federal, provincial and local } \\
\text { governments as well as among the cooperative, } \\
\text { private and public sector. }\end{array}$ & $\begin{array}{l}\text { Provincial water use, investment } \\
\text { promotion in power sector. }\end{array}$ & \\
\hline $\begin{array}{l}\text { Federal large, inter-provincial and multi-use water } \\
\text { resource development programs; mediation of } \\
\text { conflicts among provinces on water use of provincial } \\
\text { boundary rivers. }\end{array}$ & \multirow[t]{2}{*}{$\begin{array}{l}\text { Provincial level water resource } \\
\text { development programs. }\end{array}$} & \multirow{2}{*}{$\begin{array}{l}\text { Small hydropower projects; } \\
\text { alternative energy policy, } \\
\text { law, framework, project } \\
\text { implementation, regulation, } \\
\text { technology development } \\
\text { and transfer, capacity } \\
\text { development. }\end{array}$} \\
\hline $\begin{array}{l}\text { Atomic energy; alternative energy policy, laws, } \\
\text { regulation and framework. }\end{array}$ & & \\
\hline $\begin{array}{l}\text { Standards of electricity services, quality, tariff, national } \\
\text { grid; international and inter-provincial transmission } \\
\text { lines policy, framework, regulation, project } \\
\text { implementation; electricity trade policy, law and } \\
\text { regulation; investments in transmission lines. }\end{array}$ & $\begin{array}{l}\text { Electricity distribution, quality } \\
\text { regulation of services, provincial tariffs. }\end{array}$ & $\begin{array}{l}\text { Local electricity distribution } \\
\text { and service management, } \\
\text { operation and regulation. }\end{array}$ \\
\hline
\end{tabular}

Sources: Government of Nepal, Nepal Law Commission. 2015. The Constitution of Nepal. Kathmandu; Government of Nepal, Office of the Prime Minister and Council of Ministers. 2017. The Unbundling Report. Kathmandu. https:// www.opmcm.gov.np/federalism-admin/; Government of Nepal, Office of the Prime Minister and Council of Ministers. 2018. Government of Nepal Allocation of Business Rules. Kathmandu. https://www.opmcm.gov.np/ download/नेपाल-सरकार-कार्य-वभिजन/?wpdmdl=4188; and decisions by the Cabinet made public as posted on the website of the Office of the Prime Minister and Council of Ministers.

110 Based on Government of Nepal Allocation of Business Rules, 2018. 
The bulk of ADB's investment is in the electricity subsector. Nepal Electricity Authority (NEA) is one of the main implementing agencies and could well be restructured once the relevant laws at all levels of government are in place and enforced. An Electricity Regulatory Commission Act, 2017 has been enacted to establish an independent Electricity Regulatory Commission to regulate power generation, transmission, distribution and trade. ${ }^{111}$ The commission is yet to be established.

Federalism and institutional challenges in the sector are as follows:

(a) Inadequate institutional arrangements and capacity of provincial and local governments. In accordance with the federal structure of governance, provincial governments are given authority but are yet to establish or reorganize their agencies to execute their sectoral functions. Moreover, the Local Government Operations Act, 2017 includes mandates for local governments for small hydropower projects up to one megawatt capacity and alternative energy but most do not have the required institutional arrangement, capacity, or human resources to execute their functions. ${ }^{112}$

(b) Implementation challenges for transmission and distribution related activities. While it is likely that the energy projects in the pipeline will be unaffected by the federal restructuring as they will remain under federal government (as per the scope and defined outputs of the projects), projects related to transmission or having that component in the project will have to be realigned with new service providers when they are established. ${ }^{113}$ Likewise, projects with activities related to distribution would need to coordinate with provincial and local governments to align with their spheres of distribution responsibilities and for better accountability.

(c) Weak institutional capacity. Progress on the major hydropower and distribution line projects are poor with target achievement ranging from $14 \%$ to $58 \%$ in FY2017. A major reason for poor performance is weak institutional capacity, including poor inter-organizational coordination, unclear working modalities and lack of an implementation framework, including a time-bound action plan. Capacity to plan, design, implement, monitor and evaluate at national and local level remains poor.

(d) Achievements unsustainable without reform actions. Although the performance of the electricity subsector has improved in the last few years with reduced load shedding, increased access to modern electricity, and increased private sector participation, the sustainability of these achievements will depend on reform actions to effectively address some of the key institutional challenges and constraints. These include (i) inadequate investment in the subsector, (ii) an environment of nontransparent regulatory processes, (iii) an uneven playing field for stakeholders, (iv) poor interministerial coordination resulting in

111 Government of Nepal, Nepal Law Commission. 2017. Electricity Regulation Commission Act, 2017. Kathmandu.

112 Based on the Local Government Operations Act, 2017. Nepal.

113 Based on an institutional analysis of the current government agencies in Nepal. 
delays in decision-making, ( $v$ ) weak institutional and technical capacity of government agencies and NEA, (vi) ineffective project management and internal control systems for executing and implementing agencies. Moreover, although the Government of Nepal recognizes that the NEA must be unbundled and an independent regulator should be established for improved efficiency, competition, and an effectively regulated system, reforms along this line are yet to be initiated. ${ }^{114}$

\section{Public financial management}

The national PFM system covers all sectors, therefore the country-level assessment for PFM holds true for the energy sector as well. Hence, only specific sector PFM matters and challenges are discussed here. (a) The OAG 2018 annual report highlighted noncompliance and irregularities in financial operations such as excess payments and payments made without verifying documents. Budget allocation and expenses of the last three fiscal years show low capital expenditure (Table 12) and high virements, although this was reduced in the last two years (Table 13).

(b) Positive financial health of NEA is unsustainable without cost reflective tariffs and reforms in financial management. NEA made substantial progress in reducing energy loss from $25.78 \%$ in FY2016 to $22.9 \%$ in FY2017 and registered a surplus of $\$ 46.57$ million in FY2017 for the first time in many years. However, in the absence of a cost reflective tariff that

Table 12: Energy Sector Budget versus Expenditure Capital (NRs million)

\begin{tabular}{|l|c|c|c|c|c|c|c|c|c|}
\hline Fiscal Year & \multicolumn{3}{|c|}{2015} & \multicolumn{3}{c|}{2016} & \multicolumn{3}{c|}{2017} \\
\hline $\begin{array}{l}\text { Capital } \\
\text { Budget and } \\
\text { Expenditure }\end{array}$ & Budget & Expd. & Expd. \% & Budget & Expd. & Expd\% & Budget & Expd. & Expd.\% \\
\hline Amount & 1,812 & 764 & 42 & 5,400 & 544 & 10 & 8,093 & 5,903 & 73 \\
\hline
\end{tabular}

Source: Government of Nepal, Consolidated Financial Statement FY2015, FY2016, FY2017.

Table 13: Energy Sector Net Virement (NRs million)

\begin{tabular}{l|c|c|c|c|c|c|c|c|c|}
\hline Fiscal Year & \multicolumn{3}{|c|}{$\mathbf{2 0 1 5}$} & \multicolumn{3}{c|}{$\mathbf{2 0 1 6}$} & \multicolumn{3}{c|}{$\mathbf{2 0 1 7}$} \\
& $\begin{array}{c}\text { Initial } \\
\text { Budget }\end{array}$ & $\begin{array}{c}\text { Net } \\
\text { Virement }\end{array}$ & $\begin{array}{c}\text { Virement } \\
(\%)\end{array}$ & $\begin{array}{c}\text { Initial } \\
\text { Budget }\end{array}$ & $\begin{array}{c}\text { Net } \\
\text { Virement }\end{array}$ & $\begin{array}{c}\text { Virement } \\
(\%)\end{array}$ & $\begin{array}{c}\text { Initial } \\
\text { Budget }\end{array}$ & $\begin{array}{c}\text { Net } \\
\text { Virement }\end{array}$ & $\begin{array}{c}\text { Virement } \\
(\%)\end{array}$ \\
\hline Total & 3,878 & $(78)$ & 2 & 6,527 & 168 & 2.5 & 9,078 & $(58)$ & 0.64 \\
Recurrent & 1,641 & 346 & 21 & 928 & 367 & 40 & 924 & 3 & 0.35 \\
Capital & 2,237 & $(425)$ & 19 & 5,600 & $(200)$ & 3.5 & 8,154 & $(61)$ & 0.75 \\
\hline
\end{tabular}

Source: Financial Comptroller General's Office.

114 NEA has adopted a policy to establish a subsidiary company for hydropower generation under the company model. A new transmission company has been established in which NEA has $48 \%$ share. 
incorporates economic and technical costs, high system loss (22.9\% in FY2017), and poor implementation of NEA's financial restructuring plan (finalized but not yet approved), sustaining positive financial health will remain a challenge. ${ }^{115}$

(c) Internal control of NEA is weak. NEA itself has acknowledged (annual report 2017) that its internal audit does not cover all offices, is not risk based, and there is no standard format for the audit report. The Audit Committee does not monitor its activities regularly. The Committee is ineffective as there are no full-time members and it met only once in FY2017. One of the main challenges for NEA's internal audit department is the shortage of skilled human resources. ${ }^{116}$ As per the OAG 2018 report, a monthly bank reconciliation statement is not prepared. Reconciliation of loans has not been done for a long time, hence the profile of loans and debt has not been updated. Payable interest on loans was NRs.37.4 billion in 2017. Arrears of electricity tariffs have also been increasing every year. ${ }^{117}$

\section{Procurement}

The national procurement system covers all sectors, therefore the country-level assessment of procurement holds true for the sector. Some sector-specific challenges and risks in procurement are summarized below. (a) The CSPAR 2016 specifies the sector has substantial risk in all four pillars (Legislative and Regulatory Framework, Institutional Framework and Management Capacity, Procurement Operation and Market Practices, and Integrity and Transparency of the Public Procurement System). Delegating procurement authority from the NEA board to a managing director in 2016 followed by revision of the NEA financial rules is considered major progress in the sector. These changes improved portfolio performance considerably. ${ }^{118}$

(b) Cost estimates including design of construction works are not realistic and are not prepared according to the provisions of PPA and PPR. Due to the weaknesses in cost estimates, assigning significant variation orders to contractors is common. Contract variance was as high as 2.4 times of the cost estimates in a project implemented in 2017. Consultants preparing such unrealistic estimates and faulty designs are not made accountable. ${ }^{119}$

(c) Procurement planning and contract administration are weak. There are substantial delays in decision making related to procurement operations. Significant time is taken at every step of the process and contract administration, including: awarding contracts, starting works, processing variance orders, land acquisition and compensation distribution, forest

115 Aide-mémoires of the review missions.

116 Government of Nepal, NEA. 2017. Annual Report 2017. Kathmandu.

117 Footnote 41. Loan flow in NEA is quite significant but loan/debt portfolio management of NEA is weak. Basic profile of loan/debt has not been updated.

118 ADB. 2016. Nepal: Country/Sector Procurement Assessment Report 2016. Manila.

119 Footnote 118. Inadequate number of trained procurement staff and the lack of processes to carry out sufficient due diligence on bidders' background and capability have been challenges that caused delays in the overall procurement processes. 
clearance for right of way, assessment of contractor's performance, deputation of project team, filling vacant positions, resolving issues, and bill certification and payments. Delays are also caused by poor project preparedness. Management's response to issues and implementation of corrective measures is unsatisfactory. All these factors have affected timely disbursement. ${ }^{120}$

(d) The National Vigilance Center 2017 report identified several weaknesses in technical audits of hydropower projects, such as quality assurance activities not adequately organized, project milestones not defined; site register not maintained, construction materials not systematically stored and managed, and expected variation orders not managed in a timely manner.

\section{Vulnerability to corruption}

The national anticorruption system covers all sectors, therefore the country-level assessment of corruption holds true for the sector. Sectorspecific corruption risks based on the 2018 annual reports of the CIAA and OAG are summarized below.

(a) Violations of the electricity act. This involves furnishing survey licenses and amendments to those licenses. Survey licenses are renewed without a legal mandate.

(b) Noncompliance with procurement laws. For example, fragmentation of bids, unrealistic cost estimates, using the direct shopping method even for bids that are planned under bidding, bid approval by unauthorized officials, repetitive cost and time overruns, procurement of low quality transformers, over payments in the land compensation budget, and abuse and misuse of government property such as vehicles.

(c) Delayed decision-making and lack of accountability. Regulatory and monitoring bodies are found to be negligent in undertaking their duties. Recent aide memoires of ADB project review missions revealed some persisting issues, such as inadequate project monitoring, weak functioning of grievance redressal mechanisms, lack of transparency in bill certification, and lack of effective technical and public audits.

There are no PFM reform plans or programs in the sector. Nonetheless, ADB operations have been supporting some reforms in the NEA, including the preparation of NEA's Financial Restructuring Plan and a tariff increase in 2012 after 12 years.

In September 2016, the Government of Nepal issued People Investment in Nepal Hydropower outlining 37 specific medium- to long-term actions for electricity sector development. One of the main actions is to transform NEA from a loss-making entity to a profitable and efficient institution through (i) financial and institutional restructuring, (ii) revenue-generating activities, (iii) sustained recovery of arrears and control of power leaks, (iv) adoption of the right-personin-the-right position principle with performance contracting and availability of the required human resources, ( $v$ ) implementation of hydropower development through NEA subsidiaries, and (vi) efficient use of available NEA resources. ${ }^{121}$ While some of these are supported through

120 Aide-mémoire of the review mission. 12 Feb-2 March 2018 (Tripartite Portfolio Review Meetings). Among 34 actions agreed in the TPRM of June 2017, only 35\% compliance was recorded in the TPRM of March 2018.

121 ADB. 2017. Nepal Energy Sector Assessment, Strategy, and Roadmap. Manila. 
donor financed projects and TAs, these reform actions are not exclusively addressed through any programs or projects.

Regarding procurement reform, development partners (World Bank, ADB, Department for International Development, and Japan International Cooperation Agency) provided technical assistance to PPMO in the past, including ADB support, through its Strengthening Public Management Program (SPMP, 2013-2017), for the development and implementation of an e-government procurement system. Sector-specific procurement reforms are not planned under any development assistance or the Government of Nepal's own programs. Similarly, anticorruption measures are not effectively integrated or prioritized in the sector despite huge corruption risks given the large amount of public procurement (in FY2016, the total budget allocation for the energy sector was approximately $\$ 1.15$ billion or $3.63 \%$ of GDP). ${ }^{122}$

The following reform measures are proposed to address governance vulnerabilities in the sector:

(a) Institutional assessment. Given the changed institutional arrangements under the new federal structure, it is recommended that an institutional assessment of the sector is undertaken so appropriate rearrangements are made for ongoing projects. An institutional assessment, from the perspective of federalism as well as overall capacity gaps, should be made mandatory for new projects, and an institutional strengthening plan should be incorporated and implemented through the projects.

(b) Enhanced PFM system and capacity. The PFM system needs to be enhanced and staff capacities in PFM improved. Full automation of a PFM system should be advocated and possibly supported through projects and programs.

(c) Policy dialogues and missions. PFM, procurement, and corruption-related issues should be regularly raised and discussed through policy dialogues and review missions to dissuade misappropriation of funds, misprocurement, noncompliance with rules and regulations, and corrupt practices.

(d) Sector plan and project documents. For example, project design and monitoring framework (outputs and/or indicators), and covenants, and policy actions for sector development projects in consultation with energy sector colleagues so that issues are effectively addressed and reforms are achieved in selected areas, which eventually will lead to increased efficiency, effectiveness, and accountability in the sector.

(e) Digital system and training. The use of an e-GP system needs to be emphasized and training on procurement and contract management provided to all relevant officials in all government tiers in the sector. ${ }^{123}$

122 Government of Nepal, Ministry of Finance. 2015. Details of Expenditure Estimates 2015/16. Kathmandu. Nepal Electricity Authority. 2017. Annual Report 2016/17. Kathmandu.

123 Policy and technical support and advocacy to make e-GP fully functional and universally used for public procurement will need to be pursued separately. 


\section{Transport}

\section{Legal and institutional framework}

ADB has projects in civil aviation and road transport subsectors. The current and pipeline projects fall under these two categories. The road subsector continues to be guided by the National Transport Policy 2001 and the Local Infrastructure Development Policy 2004. The development and extension of the Strategic Road Network is based on the Strategic Road Master Plan 2004 and the Priority Investment Plan (2007). ${ }^{124}$ The Roads Board Act 2002, Build and Operate in Infrastructure Act 2006, and Vehicle Transport Management Act 1993 are the important sector laws that facilitate road maintenance and private investment in road construction and transport management. The Private Financing in Build and Operate in Infrastructure Act 2006 and its Regulation 2007 provide legal instruments for attracting private sector investment. Additionally, district transport master plans have been instrumental in guiding the selection and construction of district roads. The provincial governments may come up with their own plans for provincial road networks in the future. The government has accorded high priority to develop sustainable and environment-friendly roads by mobilizing communities. ${ }^{125}$

The federal constitution has assigned transport sector responsibilities of the state to all three levels of governments. The civil aviation subsector is the exclusive business of the federal government, but the road subsector is the business of all three levels. Table 14 summarizes the responsibilities of government agencies in the sector under the federal structure.

\section{Key challenges include:}

Legal gaps under the federal structure. Several laws and policies at all government tiers in line with the new constitution are yet to be formulated and approved. This is urgent as the legal gaps cause implementation delays.

\section{Weak institutional capacity of executing and implementing agencies. Almost all projects in the sector are not completed on time and suffer significant time and cost overruns, including national pride projects. For example, of the total NRs 337.8 billion allocated for five pride projects which commenced before FY2010, only NRs 35.4 billion (i.e., 10.5\%) has been spent to date. ${ }^{126}$ Table 15 shows examples of implementation delays of some national pride projects in the sector. Due to weak institutional capacity, project preparedness remains poor and causes implementation delays. Asset management and operations and maintenance of infrastructure also remains poor.}

\section{Poor institutional capacity of subnational governments. The newly established SNGs lack institutional capacity in terms of the required policies, guidelines and systems, adequate skilled human resources, financial and technical experts, development and enforcement of accountability mechanisms, and provisions for sustainability of infrastructure projects. Furthermore, poor coordination among government agencies in all tiers (vertically and horizontally) pose a challenge, particularly in project implementation. For example, projects like the urban transport project (in pipeline) will need to work with the newly established subnational governments, and in coordination with the federal Ministry of Urban Development}

124 ADB. 2017. Nepal Sector Assessment (Summary): Transport and Information and Communication Technology. Manila.

125 Footnote 124. The government has developed a 5-year strategic plan for implementation starting in 2016, focusing on the provision of safe, reliable, and all-weather access to transportation for the entire population of Nepal.

126 Footnote 41. As per the Financial Procedure Rules, 2007, ministries could provide authorizations for expenditures to their respective departments and units within 15 days from the beginning of the FY. In FY2017, offices operating under the Ministry of Physical Infrastructure and Transportation were provided authorities for additional funds at the last month of the FY. 
Table 14: Responsibilities of Government Agencies

\begin{tabular}{|c|c|c|}
\hline Government & $\begin{array}{l}\text { Ministry Department } \\
\text { Agency }\end{array}$ & Responsibilities \\
\hline \multirow{7}{*}{$\begin{array}{l}\text { Federal } \\
\text { (Road } \\
\text { subsector) }\end{array}$} & \multirow[t]{2}{*}{$\begin{array}{l}\text { Ministry of Physical } \\
\text { Infrastructure and Transport }\end{array}$} & $\begin{array}{l}\text { Responsible for road transportation, transit management other than the civil } \\
\text { aviation subsector. }\end{array}$ \\
\hline & & Formulation and execution of policies and plans. \\
\hline & \multirow[t]{2}{*}{ Department of Roads } & $\begin{array}{l}\text { Implementing agency for federal roads. The organizational structure of } \\
\text { Department of Road consists of five main departmental divisions, five } \\
\text { Regional Offices, } 34 \text { Division Road Offices, } 7 \text { Heavy Equipment Divisions, } \\
\text { and } 11 \text { Mechanical Offices. }\end{array}$ \\
\hline & & $\begin{array}{l}\text { This structure could change under the ongoing institutional restructuring } \\
\text { under the federal structure. }\end{array}$ \\
\hline & Roads Board Nepal & Provide sustainable funding for planned maintenance of roads. \\
\hline & \multirow[b]{2}{*}{$\begin{array}{l}\text { Established under the Roads } \\
\text { Board Act } 2002\end{array}$} & Collect, manage and allocate funding for road maintenance to road agencies. \\
\hline & & $\begin{array}{l}70 \% \text { of the allocated maintenance funding is for maintenance of strategic } \\
\text { road networks; } 30 \% \text { is for local road maintenance }\end{array}$ \\
\hline \multirow{3}{*}{$\begin{array}{l}\text { Federal } \\
\text { (Aviation } \\
\text { subsector) }\end{array}$} & \multirow[t]{2}{*}{$\begin{array}{l}\text { Ministry of Culture, Tourism, } \\
\text { and Civil Aviation }\end{array}$} & $\begin{array}{l}\text { Responsible for civil aviation subsector related policies, programs, plans, and } \\
\text { finances }\end{array}$ \\
\hline & & Monitoring, supervision, and reporting of programs and projects \\
\hline & $\begin{array}{l}\text { Civil Aviation Authority of } \\
\text { Nepal under Ministry of } \\
\text { Culture, Tourism, and Civil } \\
\text { Aviation }\end{array}$ & $\begin{array}{l}\text { Executes projects related to implementation of airport construction, } \\
\text { expansion and provision of airport facilities }\end{array}$ \\
\hline Provincial & $\begin{array}{l}\text { Ministry of Physical } \\
\text { Infrastructure. Other } \\
\text { implementing agencies are yet } \\
\text { to evolve. }\end{array}$ & $\begin{array}{l}\text { Responsible for road infrastructure and other infrastructure development } \\
\text { responsibilities }\end{array}$ \\
\hline Local & \multicolumn{2}{|c|}{$\begin{array}{l}\text { Local governments only have an internal department or section for roads and other infrastructure as per their } \\
\text { needs. }\end{array}$} \\
\hline
\end{tabular}

Sources: Government of Nepal, Nepal Law Commission. 2015. The Constitution of Nepal. Kathmandu; Government of Nepal, Office of the Prime Minister and Council of Ministers. 2017. The Unbundling Report. Kathmandu. https:// www.opmcm.gov.np/federalism-admin/; Government of Nepal, Office of the Prime Minister and Council of Ministers. 2018. Government of Nepal Allocation of Business Rules. Kathmandu. https://www.opmcm.gov.np/ download/नेपाल-सरकार-कार्य-वभिजन/?wpdmdl=4188; and decisions by the Cabinet made public as posted on the website of the Office of the Prime Minister and Council of Ministers.

Table 15: Progress Status of National Pride Projects

(NRs billion)

\begin{tabular}{lcccccc}
\hline Project & Start FY & End FY & Total Cost Estimate & Expense to Date & Progress (\%) \\
\hline Puspalal (Mid-Mountain) Highway & 2008 & 2018 & 33.37 & 18.96 & 58.8 \\
Kathmandu Tarai Fast Track & 2008 & 2021 & 250.00 & 4.09 & 1.6 \\
East West Railway & 2010 & 2019 & 695.17 & 6.84 & 8.8 \\
North South Highway Karnali & 2008 & 2023 & 4.10 & 0.24 & 12.5 \\
North South Highway Koshi & 2009 & 2019 & 4.08 & 1.18 & 47.2 \\
Hulaki Highway & 2007 & 2018 & 46.24 & 10.93 & 23.14 \\
& & & $1,208.5$ & 54.3 & \\
\hline
\end{tabular}

Source: OAG, 2018. 
and the Department of Roads. In the absence of clear coordination and communication mechanisms, the risk of project implementation delays will increase.

\section{Public financial management}

The national PFM system covers all sectors, therefore the country-level assessment of PFM holds true for the transport sector. Hence, only some sector PFM matters and challenges are discussed here.

Poor links between planning and budgeting. Poor resource planning in the sector has resulted in significant variations. For example, capital budget variance in FY2015, 2016 and 2017 were $11.2 \%, 27.2 \%$ and $9.2 \%$ respectively. Variances were made even though the initial budgets were not spent. The capital expenditures in those years were $82.3 \%, 69.1 \%$ and $90.1 \%$ percent of the original budget. This signifies poor resource planning and management and increased fiduciary risks. ${ }^{127}$ The OAG 2018 report revealed that the initial budget for divisional roads increased up to 312.5 times without the approval of Parliament. Despite this huge lapse in legal compliance, no one is held accountable, which increases the risks of increased noncompliance and impunity. MOPIT's initial budget also increased by $28 \%$ in FY2017 whereas it could not even spend the original budget. ${ }^{128}$

Fiscal indiscipline. Trimester expenditure data of the last three fiscal years show that more than two-thirds of the total expenditures were undertaken during the last trimester, and more specifically in the last month of the fiscal year, which raises significant risks in optimal use of resources and quality of procured products and services. The practice of holding a large amount of unallocated budget in the ministry and distributing it to the spending units in the third trimester is prevalent, which is against the financial procedural laws and contributed to increased fiduciary risks. For example, MOPIT distributed $21 \%$ and $10.6 \%$ of the total capital budget in the third trimester from unallocated funds in FY2017. The OAG 2018 report uncovered irregularities in payments. For example, additional advances, payments without relevant documents and without deducting taxes, increasing audit backlogs, and poor follow-up actions and audit observations giving rise to poor accountability and impunity. ${ }^{129}$

\section{Procurement}

The national procurement system assessment covers procurement related policies and issues common in all the sectors, therefore this section only includes issues and challenges specific to this sector.

Transport is a high-spending sector in Nepal. Its annual budget is over $2 \%$ of GDP, $39 \%$ of which comes from bilateral and multilateral support. Up to 2017 , it received $\$ 978$ million in loans and grants from ADB for executing 63 projects and programs. Some progress has been achieved in procurement operations and market practices, as exemplified by (i) a marked improvement in ADB disbursement in FY2016 and 2017, (ii) improvement in contract awards within the original bid validity period, (iii) formalization of a permanent procurement unit, and (iv) use of Single-Stage Two-Envelope Bidding which has led to the harmonization of government procedures with ADB practice. ${ }^{130}$

127 Footnote 90. Though a ministry prepares the medium-term expenditure framework as a 3-year rolling plan, linkage between national and subnational plans and processes remain unclear.

128 Footnote 41. Construction of roads in Nepal are also carried out by the Ministry of Urban Development and subnational governments, except for the Department of Roads. Close coordination among these entities is hence critical.

129 Footnote 41. Total outstanding advances under the Ministry of Physical Infrastructure and Transportation in FY2017 was NPR27.12 billion ( $\$ 271.21$ million).

130 ADB, 2018. Nepal: An update of country/sector procurement assessment report Draft Final Report. June 2018. 
The CSPAR 2016 and the 2018 update shows that procurement risks associated with this sector are substantial in two pillars (Procurement Operations/Market Practices and Integrity and Transparency of the Public Procurement System), and moderate in two other pillars (Legislative and Regulatory Framework, and Institutional Framework/Management Capacity). Some procurement-related challenges in the sector are:

(a) Procurement proceedings are initiated without the provision of a budget. The OAG 2018 report found that MOPIT received assurance from $\mathrm{MOF}$ for additional budget to implement 654 additional projects. Accordingly, MOPIT initiated several infrastructure projects without appropriation of the necessary budget or approval from the NPC, which is against the PPA. ${ }^{131}$

(b) Cost estimates, including design of construction works, are not prepared according to the provisions of the PPA/ PPR resulting in a significant number of variation orders. The Parliamentary PAC raised serious concerns over inclusion of irrelevant expenses in bills of quantities, for example vehicle rentals and purchases. ${ }^{132}$

(c) Sector agencies practice inappropriate slicing and packaging to avoid or limit competition and is against the PPA/PPR. According to the PPMO 2017 report, the direct shopping method was used even in cases where bidding was required, and the bid values of construction works were increased to favor participation of only a few large contractors. For example, the Department of Roads prepared two packages for 33 and 43 bridges respectively and only two bidders participated in the process and won the contracts. ${ }^{133}$

(d) Procurement capacity and contract management of executing and implementing agencies are weak. Due to the high turnover of staff, several positions have remained vacant for some time and there is a lack of commitment in filling these positions. ${ }^{134}$ There are substantial delays in decision making related to procurement operations. Management response to issues and implementation of corrective measures remains weak. ${ }^{135}$

(e) The National Vigilance Center 2017 report found various weaknesses during technical audits of the projects under the MOPIT. These include quality assurance activities not adequately organized, contract completion periods not based on the magnitude of the works, poor supervision, project completion periods not extended on time, contractor's performance not assessed, and project milestones not defined.

\section{Vulnerability to corruption}

The 27th annual report of the CIAA indicated corruption trends and governance vulnerabilities leading to corruption in the transport sector. ${ }^{136}$ These include the following:

131 Footnote 41. The transport sector remains to have one of the highest spending rates in Nepal.

132 Footnote 41 . Work contract variations are common in Nepal. The authority of sanctioning $10 \%$ variations lies within the respective project managers. The departmental head is authorized to sanction up to $15 \%$. For approval above $15 \%$, it has to get the approval of the Cabinet.

133 PPMO. 2017. Consolidated Report of Public Procurement Monitoring and Complaints. Nepal.

134 Aide-mémoires of ADB review missions.

135 Aide-mémoire of the review mission. Tripartite Portfolio Review Meetings (12 Feb-2 March 2018). specifies that among 31 actions agreed in June 2017, only 48 percent compliance recorded in February/March 2018.

136 CIAA. 2018. 27th Annual Report of CIAA. Nepal. 
(a) Misappropriation of funds. Misuse of revenues in Transport Management Offices, double payments, expenses made outside the budget, unrealistic cost estimates, acceptance of price escalation without scrutiny.

(b) Inactions against those guilty. There are many instances of jobs not done after receiving mobilization advance by contractors. Actions against those contractors are not taken promptly. Poor performance of consultants is rarely punished. Noncompliance and collusive practices among bidders and with government officials are overlooked, giving rise to impunity.

(c) Forgery. Several cases of forgery have been reported, such as, forged user committees, use of forged documents in contract processing and payments, and malpractice in airline license renewals.

There are no sector-specific PFM, procurement, or anticorruption reform plans or programs run by sector agencies on their own or with development partner support in the transport sector. The following reform measures are proposed to address the governance vulnerabilities in the sector:

(a) Institutional assessment and strengthening of executing and implementing agencies of all government tiers. it is recommended that an institutional assessment of the sector is undertaken so that appropriate rearrangements are made for ongoing projects in the federal context. An institutional assessment should be made mandatory for new projects, and appropriate technical and policy advisory support for institutional strengthening and capacity development are included in the projects and programs. An asset management system in the sector needs to be established with clear functional responsibilities for operations and maintenance in all government tiers.

(b) Enhanced public financial management system and capacity. The PFM system needs to be enhanced and staff capacity improved. Full automation of the PFM system enhances efficiency, transparency and accountability and should be advocated and possibly supported through projects and programs.

(c) Policy dialogues and missions. Fiscal indiscipline, noncompliance with procurement laws and regulations, and corrupt practices in the sector should be condemned through policy dialogues and review missions. Strengthening of internal control systems, regular monitoring and supervision, and enforcement of accountability mechanisms, such as public audits and third-party monitoring would address the indiscipline and noncompliance issues to a large extent.

(d) Reform measures. Sector plan and project documents (e.g., project design and monitoring framework under outputs and/or indicators, covenants, and policy actions for sector development projects) should include PFM, procurement, and anticorruption reform measures so risks are effectively addressed and mitigated and reforms are achieved. This will eventually lead to increased efficiency, effectiveness, and accountability in the sector and timely achievement of project outcomes. ADB officials responsible for the sector and public management experts should work together to integrate reform measures in projects and programs to effectively address these risks. 
(e) Digital system and training. The use of the e-GP system needs to be emphasized and training on procurement and contract management provided to all relevant officials in all government tiers in the sector. ${ }^{137}$

\section{E. Water and Other Urban Infrastructure and Services Sector}

\section{Institutional and legal framework}

The federal constitution of Nepal has assigned state responsibilities for the urban and water sector to all three levels of government. Responsibilities for urban development under the federal structure lie with the Ministry of Urban Development (MOUD) and the Ministry of Water Supply. The institutional arrangements of implementing agencies and other specialized agencies at the federal level remain unchanged. The provincial ministries responsible for the sector are: Ministry of Social Development and Ministry of Physical Infrastructure.

Implementing agencies at the provincial level are yet to be established. The federal government has handed over regional and divisional offices under this sector to the provincial governments. Metropolitan and submetropolitan cities have separate units and divisions responsible for urban governance and infrastructure development. Rural local governments only have one or two civil engineers or junior engineers or technicians. ${ }^{138}$ Table 16 shows the institutional framework in the sector.
The National Urban Policy, 2007 is a guiding document for urban development in Nepal. It aims for balanced urban structure, development of safe and prosperous urban centers, and effective urban management. In line with this policy, the National Urban Development Strategy, 2017 was developed with a vision for the next 15 years (Vision 2031). The National Urban Water Supply and Sanitation Policy 2014 targets coverage of 100 percent of the population with basic services. The Water Supply Management Board (WSMB) Act 2006 emphasizes involvement of local governments in water supply and wastewater sector development in urban areas. It allows private sector involvement in the management, and operation and maintenance of systems. ${ }^{139}$

To improve water supply and sewerage services in Kathmandu Valley, Nepal Water Supply Corporation was restructured into three separate entities: (i) Kathmandu Valley WSMB which owns the assets of water supply and sewerage infrastructure in Kathmandu Valley and is responsible for the development and provision of water supply and wastewater services; (ii) Kathmandu Upatyaka Khanepani Limited (KUKL), ${ }^{140}$ the service operator of Kathmandu Valley WSMB; and (iii) Water Supply Tariff Fixation Commission, responsible for the economic regulation of services and tariff fixation for the country. ${ }^{141}$ Separate water supply management boards are also established in some municipalities (Hetauda and Bharatpur) under the WSMB Act. Nepal Water Supply Corporation continues to be the utility operator

137 Policy and technical support and advocacy to make e-GP fully functional and universally used for public procurement will also need to be pursued separately.

138 Based upon OPMCM. 2018. Government of Nepal Allocation of Business Rules. Nepal.

139 ADB. 2017. Nepal Sector Assessment (Summary): Water Supply and Other Municipal Infrastructure and Services. Manila.

140 KUKL's shareholders are the Government of Nepal (30\%), Kathmandu Metropolitan City (30\%), Lalitpur Submetropolitan City (10\%), Nepal Chamber of Commerce (15\%), KUKL employees (5\%) and Bhaktapur, Madhyapur Thimi and Kirtipur Municipalities (10\%). KUKL has a 30-year lease agreement with KVWSMB for service delivery. Source: ADB Nepal Sector Assessment: Water Supply and other Municipal Infrastructure and Services. 2017. Kathmandu.

141 The restructuring was undertaken as a part of ADB financed Loan NEP 2058/2059: Kathmandu Valley Water Services Sector Development Program. 2008. 
Table 16: Institutional Framework in Urban and Water Sector in the Federal Context

\begin{tabular}{|c|c|}
\hline Government Tiers, Agencies & Roles and Responsibilities \\
\hline \multicolumn{2}{|r|}{ Federal } \\
\hline Ministry of Urban Development & $\begin{array}{l}\text { - Federal policy, laws and standards on urban development, habitat, } \\
\text { human settlements, housing and buildings }\end{array}$ \\
\hline Implementing Agency: & - National building codes \\
\hline Department of Urban Development & - Central government buildings \\
\hline (for project implementation) & - National urban infrastructure development \\
\hline & - Specialized city structures \\
\hline & - Inter-agency and international coordination \\
\hline Ministry of Water Supply & - Federal water supply and sanitation policy, laws and standards \\
\hline Implementing Agencies: & - National large water supply, sanitation and sewerage \\
\hline Department for Water Supply and & - Inter-provincial water supply \\
\hline $\begin{array}{l}\text { Sewerage Management Kathmandu } \\
\text { Upatyaka Khanepani Limited }\end{array}$ & - Inter-agency and international coordination \\
\hline \multicolumn{2}{|r|}{ Provincial } \\
\hline Chief Minister's office & Coordination among local governments \\
\hline Ministry of Social Development & $\begin{array}{l}\text { Responsible for water supply: formulation of relevant laws, policies } \\
\text { and regulations, planning, coordination, tariff determination, project } \\
\text { development, management, operations and maintenance }\end{array}$ \\
\hline Ministry of Physical Infrastructure & $\begin{array}{l}\text { Responsible for urban infrastructure: formulation of relevant laws, } \\
\text { policies, regulations, planning, coordination, project development, } \\
\text { management, operations and maintenance }\end{array}$ \\
\hline \multicolumn{2}{|r|}{ Local } \\
\hline Divisions and Units & $\begin{array}{l}\text { Formulation of local policies, regulations, guidelines, planning, } \\
\text { development and management of all local infrastructure }\end{array}$ \\
\hline
\end{tabular}

Sources: Government of Nepal, Nepal Law Commission. 2015. The Constitution of Nepal. Kathmandu; Government of Nepal, Office of the Prime Minister and Council of Ministers. 2017. The Unbundling Report. Kathmandu. https:// www.opmcm.gov.np/federalism-admin/; Government of Nepal, Office of the Prime Minister and Council of Ministers. 2018. Government of Nepal Allocation of Business Rules. Kathmandu. https://www.opmcm.gov.np/ download/नेपाल-सरकार-कार्य-वभिजन/? wpdmdl=4188; and decisions by the Cabinet made public as posted on the website of the Office of the Prime Minister and Council of Ministers.

for water services outside Kathmandu Valley. In small towns, water supply and sewerage services may also be provided and operated by water user associations and their water user steering committees.

While the provinces are yet to formulate their sector laws, the Local Government Operations Act, 2017 gives them responsibilities for policy formulation, regulations, planning, and implementation related to urban development and environment, water resources, water supply, and sanitation.
Weak institutional capacity, particularly at the local government level is a major challenge in delivering efficient services. Sectoral acts, policies and guidelines are yet to be formulated and approved in provinces and local governments. Clear functional demarcation among all government tiers for sector operations are not fully established, causing confusion. Appropriate systems and processes for administrative, financial, and project management are yet to be put in place in many local governments. Moreover, several local governments are unable to undertake 
their mandated functions due to an inadequate number of administrative, financial, and technical staff and their weak capacity. Asset management systems are not maintained, and maintenance of urban infrastructure remains poor. Tax rates, water tariffs, and service fees are not set at a level needed to sustain operation. All these factors have hindered effective planning, budgeting, project design and implementation, monitoring and supervision, and service delivery. ${ }^{142}$

\section{Public financial management}

$A D B$ is a key development partner in water and the urban infrastructure sector in Nepal with a large portfolio of projects. In FY2016, the total budget allocation accounted for approximately $1.5 \%$ of GDP. Up to 2017, the sector received $\$ 986$ million in loans and grants from ADB for executing 56 projects and programs. ${ }^{143} A$ sound PFM system and low fiduciary risks are critical to safeguard these investments and ensure resources are used for intended purposes. Some PFM challenges in the sector that need to be addressed are:

(a) Weak links between planning and budgeting. Before the completion of ongoing projects, new projects get added every year. For example, of the 5,037 drinking water projects implemented in FY2017, 2,693 were ongoing projects and 2,344 were new. This shows weak planning and lack of prioritization. Cost estimates of the ongoing projects were NRs 19.31 billion but only NRs 9.23 billion (i.e., 47.8\%) had been spent up to 2017. Among the ongoing projects, 449 drinking water projects in 63 districts were commenced before FY2012 but remain incomplete. Project completion periods are often extended and contract variations are common and add to increased project costs. ${ }^{144}$

(b) Spending capacity. There is underuse of loans and grants. ${ }^{145}$ For example, capital expenditures were $63.1 \%$ in FY2015, 76.5\% in FY2016, and 74.4\% in FY2017 of the allocated budgets; despite the underspending, capital budget variances were noted in FY2015 (6.8\%), FY2016 (13.4\%), and FY2017 (9.3\%) as additional budgets were provided. ${ }^{146}$ This shows poor financial management and fiscal indiscipline.

(c) Fiscal indiscipline. The OAG 2018 report highlighted cases of fiscal indiscipline in the sector. For example, payments made without adequate supporting documents and their verification, budgets are not released on time, and additional advances were given before settling previous ones.

(d) Public financial management in local governments. Local governments are the main implementing agencies of sector programs and projects. The PFM systems in most local governments are not digitized, and even if they are, different information and communication technology

142 In ADB supported Small Towns Projects, setting water tariffs is done in accordance with the TDF tariff guidelines and in accordance with the Urban Water Supply and Sanitation Sector Policy. A recent IED impact study confirmed this. https://www.adb.org/documents/impact-cost-shared-water-supply-services-household-welfare-small-towns-expost-impact.

143 ADB, 2018. Nepal: An update of country/sector procurement assessment report draft final report. Nepal.

144 Footnote 41. The gap between planning and budgeting is more acute in local governments, which execute most of the urban and water projects under the federal structure.

145 Aide-mémoires of ADB Review Missions.

146 FCGO. 2017. Consolidated Financial Statements 2015, 2016 and 2017. Nepal. 
systems and software are used for different PFM functions. Also, the systems are not uniform across local governments, which makes financial monitoring and comparative analysis difficult. Although many urban local governments (municipalities) have internal audit units, they are not sufficiently staffed, are ineffective, and do not include internal control measures. Financial reporting from several local governments is scanty, not comprehensive, and accounts are not reconciled. Fiduciary risks in many local governments therefore remain high. Local governments largely depend on central transfers as they raise negligible local revenue due to inadequate revenue bases (in several, none at all), weak institutional capacity and knowledge base, inadequate and unskilled human resources, and a low priority PFM. Challenges and weaknesses in local government PFM are discussed in more detail in the Country Assessment Report, Chapter III (Use of Country System).

\section{Procurement}

The CSPAR 2016 and the 2018 update show that procurement risk associated with this sector is substantial in one of the four pillars (Integrity and Transparency Public Procurement System), and moderate in the other three pillars (Legislative and Regulatory Framework, Institutional Framework/Management Capacity, and Procurement Operations/Market Practices), indicating that the overall procurement risk is moderate. ${ }^{147}$ Some key challenges and issues are summarized as follows: (a) The OAG 2018 report mentioned that legal provisions were not followed in project works executed through user committees. For example, spending units did not deduct overhead expenses and peoples' contributions from payments as required by the PPA. Ownership of community and committee managed projects is not transferred and maintenance costs are being borne by the spending units. Slicing of procurement packages to award the work to user committees instead of going for competitive bidding was also noted. Norms for construction works were approved by the department chief when they should have been approved by the Council of Ministers. Inconsistency in construction norms in various entities was also found. ${ }^{148}$

(b) Procurement capacity, contract management, and technical knowledge, of local governments is poor. In the absence of sector-specific standard procurement documents and guidelines, procurement processes and decision making in local governments is often delayed. This is compounded by the lack of adequate and skilled procurement experts. There are delays in approving variance orders and payments as well. Due to inadequate technical experts, engineering designs and cost estimates are often poor and inaccurate, and supervision and monitoring are ineffective leading to low quality infrastructure. ${ }^{149}$ Due to the lack of adequate technical staff, one project manager is required to manage several projects and does not have time for proper supervision, monitoring, addressing grievances, coordinating, and reporting.

147 ADB. 2016. Nepal: Country/Sector Procurement Assessment Report 2016. Nepal.

148 Footnote 41. Procuring entities are required to prepare annual procurement plans, but several entities do not comply. This is more challenging at the subnational level.

149 ADB. 2018. Nepal: An Update of Country/Sector procurement Assessment Report. 2018. 
(c) Poor contract management is exemplified by irregular and ineffective performance management and evaluation systems of consultants and contractors, and nonaction against poor performers. Management response to issues and implementation of corrective measures is weak. ${ }^{150}$ Most projects are not completed within the stipulated time. Contract periods are repeatedly extended creating substantial financial burdens. For example, the original completion date of the Melamchi Water Supply Project was FY2008 but is yet to be completed despite a fourth extension. Additional advances were reported to have been provided to the project contractor against the opinion of the financial administration. ${ }^{151}$

(d) The e-government procurement system is not widely used by local governments although this has been made mandatory for all procurements above NRs 6 million. Reasons for nonuse include inadequate technical support for its operation and troubleshooting, insufficient orientation to users (government and private sector), and the lack of enforcement for its use by concerned authorities.

\section{Corruption}

Based on the 2018 annual reports of the CIAA and the OAG, major incidents of corruption and corrupt practices and risks in the sector have been reported.

(a) Misappropriation of funds. Payments made without any performance or for inferior performance and without adequate supporting documents, new advance given before settling the previous advance, compensation payments made for illegally captured public lands, payments made on forged invoices, misuse of contingency funds.

(b) Noncompliance with laws and policies. Fragmented or sliced bidding, unjustified variation orders and price escalations, complex engineering works given to user committees, operation and maintenance costs of projects built by user committees are borne by implementing agencies, poor supervision and monitoring by regulatory authorities, inconsistency in the norms of construction adopted by various entities, and OAG audit objections not addressed.

(c) Corrupt practices. Issues among user committees include (i) formation of forged beneficiaries (users) committees, (ii) work not done by members of the user committees but by contractors hired by them (against the PPA), (iii) public participation and compulsory contributions by members of user groups are neither ensured nor deducted from the project costs and payments, and (iv) issuance of forged project completion certificates.

The reports have highlighted that due to the poor PFM system, weak procurement capacity, ineffective supervision and monitoring, and inadequate technical, procurement, and finance experts, corruption risks in local governments have increased. Also, collusive practices among local government authorities, political parties, and user committees were observed but rarely are any actions taken.

150 Aide-mémoire of the ADB review mission. 12 Feb-2 March 2018 (Tripartite Portfolio Review Meetings). Among 34 actions agreed in the TPRM of June 2017, only 35 percent compliance was recorded in the TPRM of March 2018.

151 Footnote 41. Within 3 days of the conclusion of a procurement contract, the public entity is required to publish relevant information of the contract. But in the absence of a procurement or contract management information system (at the public procurement monitoring office), effective monitoring and oversight of public contracts become more challenging. 
ADB's aide-mémoires of recent project review missions have also indicated several issues related to corrupt practices, such as apathy to public concerns, ineffective grievance handling mechanisms and compliance monitoring, and uncoordinated urban utilities and infrastructure development resulting in duplication of works. ${ }^{152}$

Reform priorities in urban and water sector and recommendations for ADB. Some proposed reform measures to address the governance risks in the Urban and Water Sector as follows:

(a) Most ongoing ADB projects in the sector are closing before the implementation of the Country Partnership Strategy. For new projects, it is recommended that an institutional assessment of executing and implementing agencies is undertaken to (i) establish appropriate institutional arrangements for project execution, (ii) clearly demarcate roles and responsibilities among agencies at all government tiers, (iii) identify institutional gaps and risks for efficient project management and service delivery, such as policies, regulations, guidelines, systems, operational challenges, capacities, and resources. An institutional strengthening or reform plan should then be developed to address the identified challenges and risks. The reform plan needs to be incorporated into the sector road map and implemented through projects and programs.

(b) The existing PFM system in local governments does not provide the assurance that financial resources will be used for intended purposes and value for money will be achieved. Robust PFM systems in local governments is therefore critical to reduce fiduciary risks and corrupt practices. Digitization and uniformity of the PFM system across all local governments, along with effective internal control mechanisms and expenditure reporting will improve financial monitoring, accountability, and reduce fiscal indiscipline, hence should be advocated through policy dialogues and supported through projects and programs. Additionally, policy dialogues and project support to increase local revenue is recommended as this will enhance local government capacity for better service delivery and without having to depend on central transfers for all development work. This will also promote public accountability. Several urban municipalities and local governments have a significant revenue base but it is not exploited for several reasons, including low institutional capacity and unavailability of experts in tax administration. Policy advisory and technical support in mobilizing local revenues in large local governments, to start with, would make them more independent, resource rich, and capable of improving service delivery.

(c) Institutional capacity of local governments for procurement and contract management needs to be strengthened. Local governments need adequate and trained procurement staff to undertake procurement processes efficiently and technical staff and engineers to design, implement, and supervise infrastructure projects. Support should be provided to the government to formulate and enforce policy on conflict of interest. Mechanisms to discourage collusive and corrupt practices need to be set up. The use of the e-GP system is one effective mechanism and should be emphasized. ${ }^{153}$ Training on procurement and contract management needs to 
be prioritized for all relevant officials. Procurement guidelines specific to the sector need to be prepared. Roles and responsibilities among all relevant entities in all government tiers and procedures for procurement need to be clarified. These should be supported through regular policy dialogues with the government and through policy advisory and technical support through programs and projects.

(d) Appropriate institutional mechanisms and plans of action to prevent collusive and corrupt practices should be put in place. For example, implementation and enforcement of accountability mechanisms, such as public audits of all infrastructure projects, public hearings to account for the annual budget and expenditures, and social audits to assess the effectiveness and efficiency of public services. Final payments should be tied to public audits. Increased participation and transparency in the formation of user committees should be advocated. There are some established community forums and groups (e.g., mothers' groups, farmers' groups, citizen awareness centers), which could be mobilized to facilitate the process of forming different committees such as user, monitoring, planning, and accounts committees. Again, all these could be supported through regular policy dialogue and through policy advisory and technical support through programs and projects.

153 Policy on technical support and advocacy to make e-GP fully functional and universally used for public procurement will need to be pursued separately. 


\section{APPENDIX 1}

\section{List of Persons Met During the Consultation Meetings}

\section{A. Kathmandu}

1. Baburam Gautam, Deputy Auditor General, OAG, Kathmandu

2. Madhu Regmi, Secretary, PPMO

3. Sunil Karna, Joint Secretary, PPMO

4. Murari Niraula, Member Secretary, PEFA Secretariat

5. Kedar Bahadur Adhikari, Secretary, OPMCM

6. ChiranjivJha, Senior Divisional Engineer, NVC

7. Hari Bahadur Thapa, Senior Divisional Engineer, NVC

8. Maheshwor Neupane, Secretary, CIAA

9. Rameshwor Dangal, Joint Secretary, CIAA

10. Hari Prasad Lamsal, Joint Secretary, Ministry of Education, Singha Darbar

11. Dhrub Raj Regmi, Under Secretary, Ministry of Education, Singha Darbar

12. Ghanshyam Aryal, Under Secretary, Department of Education

13. Mukund Pokhrel, Chief Account Officer, Ministry of Education

14. Ishwari Datta Bhatta, Project Director, SDP, Ministry of Education

15. Dhrub Babu Marhatta, Account Officer, SDP, Ministry of Education

16. Kul Man Ghising, MD, NEA;

17. Manoj Silwal, Officiating DMD, Project Management Directorate, NEA

18. Lekhnath Koirala, Acting DMD, Finance Directorate, NEA

19. Tiresh Prasad Khatri, Project Director, Melamchi Subproject 2, PID, KUKL

20. Dhrub Raj Regmi, Adviser to Kathmandu Valley Water Supply Management Board (KVWSMB)

21. Ishwor Prasad Kafle, Finance Manager, Melamchi Subproject 2, PID, KUKL

22. Dipendra Nath Sharma, Secretary, MOUD

23. Rajendra Kumar Paudel, Joint Secretary, MOUD

24. Shiv Hari Sharma, DG, Department of Urban Development

25. Ashish Ghimire, Project Director, Bagmati River Basin Improvement Project

26. Keshab Kumar Sharma, Joint Secretary, Foreign Aid and Quality Standard Division, MOPIT

27. Rajendra Raj Sharma, Joint Secretary (Technical), Planning, Monitoring and Evaluation Division, MOPIT

28. Saroj Pandit, DG, Dol

29. Hari Narayan Yadav, Senior Divisional Engineer, Dol

30. Noor Mohammad Khan, Project Director, CMIASP-AF

31. Saroj Kumar Pradhan, Joint Secretary, Department of Roads, ADB - Project Directorate

32. Saurabh Bajracharya, Senior Divisional Engineer, Department of Roads, ADB - Project Directorate

33. Pradip Raj Shakya, Engineer, Department of Roads, ADB - Project Directorate 
34. Ram Krishna Pudasani, Under Secretary (Accounts), Department of Roads, ADB - Project Directorate

35. Bishnu Bhai Shrestha, President, Federation of Contractors Association of Nepal (FCAN)

36. Yaksha Dhoj Karki, former President, FCAN

37. Ang Dorji Lama, former Member, FCAN

38. Ram Sharan Deuja, Secretary General, FCAN

39. Baburam Dahal, Advocate, Supreme Court (Adviser, FCAN)

40. Ram Prasad Kharel, Deputy Executive Director, Melamchi Drinking Water Project

41. Dinesh Adhikari, Senior Divisional Engineer, Ministry of Water Supply

42. Prakash Pudasaini, Under Secretary (Accounts), Ministry of Water Supply

43. Yubak Dhoj G.C., Secretary, Ministry of Agriculture, land management and Cooperatives

44. Tej Bahadur Subedi, Joint Secretary, Policy and Foreign Aid Coordination Division, Ministry of Agriculture, Land Management and Cooperatives

45. Dal Prasad Pudasaini, Senior Agriculture economist, Ministry of Agriculture, Land Management, and Cooperatives

46. Roshan Bajracharya, Senior Economist, World Bank Nepal

47. Bigyan Pradhan, Senior Operations Officer, World Bank Nepal

48. Shrikrishna Nepal, JS, International Economic Cooperation and Coordination Division, MoF

49. Laxman Aryal, Secretary, NPC

50. Purushottam Nepal, JS, MOFAGA

51. Gareth Rannamets, DFID

52. Yam Nath Sharma, UNDP

53. Sanjib Gautam, Director General, CAAN

54. Baburam Poudel, Project Director, ATCEP/TPPF, CAAN

55. Dipendra Shrestha, Deputy Project Director, ATCEP/TPPF, CAAN

\section{B. Morang/Jhapa}

1. Sher Dhan Rai, Chief Minister, Province No. 1, Biratnagar

2. Indra Bahadur Angwo, Minister for Economic Affairs and Planning, Province No. 2, Biratnagar

3. Naresh Prasad Pokhrel, DCC Chairperson, Morang

4. Krishna Kumar Mishra, Chief District Engineer, DCC, Morang

5. Suresh Pradhan, Principal Secretary, Chief Minister's Office, Province No. 2, Biratnagar

6. Sagar Kumar Rai, Secretary, Ministry of Physical Infrastructure, Province No. 2, Biratnagar

7. Prahlad Sapkota, Secretary, Ministry of Economic Affairs and Planning, Province No. 2, Biratnagar

8. Kishore Baral, Chief District Treasury Controller, DTCO, Morang

9. $\quad$ Santosh Kumar Dungana, President, FCAN, Morang

10. Dipendra Karki, Former President, FCAN, Morang, Contractor

11. Raj Kumar Thapa, District Education Officer, District Education Office, Morang

12. Rajendra Budhathoki, Under Secretary, District Education Office, Morang

13. Bhim Parajuli, Mayor, Biratnagar Metropolitan City

14. Indira Karki, Deputy Mayor, Biratnagar Metropolitan City

15. Kumar Prasad Dahal, Chief Executive/Administrative Officer, Biratnagar Metropolitan City

16. Bharat Kumar Neupane, Project Manager, STIUEIP/RUDP, Biratnagar Metropolitan City

17. Prakash Narayan Chaudhary, Deputy Project Manager, STIUEIP/RUDP, Biratnagar Metropolitan City 
18. Punam Kumar Dahal, Social Development Officer, STIUEIP/RUDP, Biratnagar Metropolitan City

19. Mister K.C., Account Officer, STIUEIP/RUDP, Biratnagar Metropolitan City

20. Ghanashyam Kafley, Project Engineer, RUDP, Biratnagar Metropolitan City

21. Purushottam Lamichhane, Administrative Assistant, STIUEIP/RUDP, Biratnagar Metropolitan City

22. Tilak Bahadur Khatry, Senior Divisional Engineer, CMISP/Irrigation Directorate, Morang

23. Satya Narayan Mandal, Agriculture Specialist, CMIASP/AF, Morang

24. Rishiram Koirala, CMIASP/AF, Morang

25. Sachidanand Yadav, Regional Chief, Eastern Regional Office, NEA, Biratnagar

26. Sailesh Sapkota, Divisional In-Charge, SASEC/Distribution Project

27. Kanhaiya Lal Rajbanshi, Ward Chairperson, W.N. 5, Ratuwamai Municipality, Morang

28. Hom Prasad Pokhrel, Ward Secretary, W.N. 5, Ratuwamai Municipality, Morang

29. Romnath Oli, Mayor, Damak Municipality, Jhapa

30. Gita Adhikari, Deputy Mayor, Damak Municipality, Jhapa

31. Ganesh Prasad Timsina, Chief Executive/Administrative Officer, Damak Municipality, Jhapa

32. Shambhu Karki, Senior Divisional Engineer/Project Manager, RCIP. CIP/Project Implementation Unit, Damak

\section{Kailali/Kanchanpur}

1. Trilochan Bhatta, Chief Minister, Province No. 7, Dhangadhi

2. Jhapat Bahadur Bohora, Minister, Ministry of Economic Affairs and Planning, Province No. 7, Dhangadhi

3. Binita Devi Chaudhary, Minister, Ministry of Land Management, Agriculture and Cooperatives, Province No. 7, Dhangahdi

4. Laxminath Paudel, Principal Secretary, Office of Chief Minister and Council of Minister, Province No. 7, Dhangadhi

5. Baburam Shrestha, CDO, Kailali

6. Shankar Krishna Shrestha, Secretary, Ministry of Economic Affairs and Planning,

Province No. 7, Dhangadhi

7. Harihar Adhikari, Secretary, Ministry of Land Management, Agriculture and Cooperatives, Province No. 7, Dhangadhi

8. Surya Bahadur Thapa, Chairperson, District Coordination Committee, Kailali, Dhangadhi

9. Nripa Bahadur Odd, Mayor, Dhangadhi Submetropolitan City, Dhangadhi

10. Surendra Bista, Mayor, Bheemdatta Municipality, Mahendranagar

11. Sushila Mishra Bhatta, Deputy Mayor, Dhangadhi Submetropolitan City, Dhangadhi

12. Sushila Chand Singh, Deputy Mayor, Bheemdatta Municipality, Mahendranagar

13. Amar Bahadur Pal, Senior Divisional Engineer, Ministry of Physical Infrastructure and Development, Dhangadhi

14. Ganesh Marasini, Division Chief, Irrigation Development Division, Kailali

15. Yadav Mainali, Engineer, Irrigation Development Division, Kailali

16. Netra Paudel, Engineer, Irrigation Development Division, Kailali

17. Santa Bahadur Sunar, Chief Administrative Officer, Dhangadhi Submetropolitan City, Dhangadhi 
18. Devi Datta Bhatta, Livestock Development Officer (PA to Minister), Ministry of Land Management, Agriculture and Cooperatives, Province No. 7, Dhangadhi

19. Pradip Raj Kandel, Under Secretary, Office of Chief Minister and Council of Minister, Province No. 7, Dhangadhi

20. Gyanendra Prasad Dhakal, Acting Chief, CIAA Regional Office, Mahendra Nagar

21. Prem Sagar K.C., DSP, CIAA Regional Office, Mahendra Nagar

22. Harish Chandra Joshi, Section Officer, CIAA Regional Office, Mahendra Nagar

23. Laxmi Datta Bhatta, Division Chief (SDE), Roads Division Office, Mahendra Nagar

24. Narendra Singh Bishta, Coordinator, PCU, LGCDP II, Dhangadhi

25. Yagya Raj Awasthi, Ex. District Coordinator, Raising Income of Small and Medium Farmers Project, Dhangadhi 


\section{APPENDIX 2}

\section{Overview of Country Governance Surveys}

This annex presents the main findings for Nepal from several international governance surveys between 2008 and 2018 depending on availability of data on Nepal.

\section{A. World Bank Institute Worldwide Governance Indicators}

The WGIs ${ }^{1}$ capture six key dimensions of governance and measure the quality of governance in over 200 countries. $^{2}$ They compile perceptions from a diverse group of respondents collected in surveys and other cross-country assessments. The WGIs for Nepal for 2008-2016 (up-to-the-year data is available) are shown in the figure. ${ }^{3}$

\section{World Bank Institute WGIs}

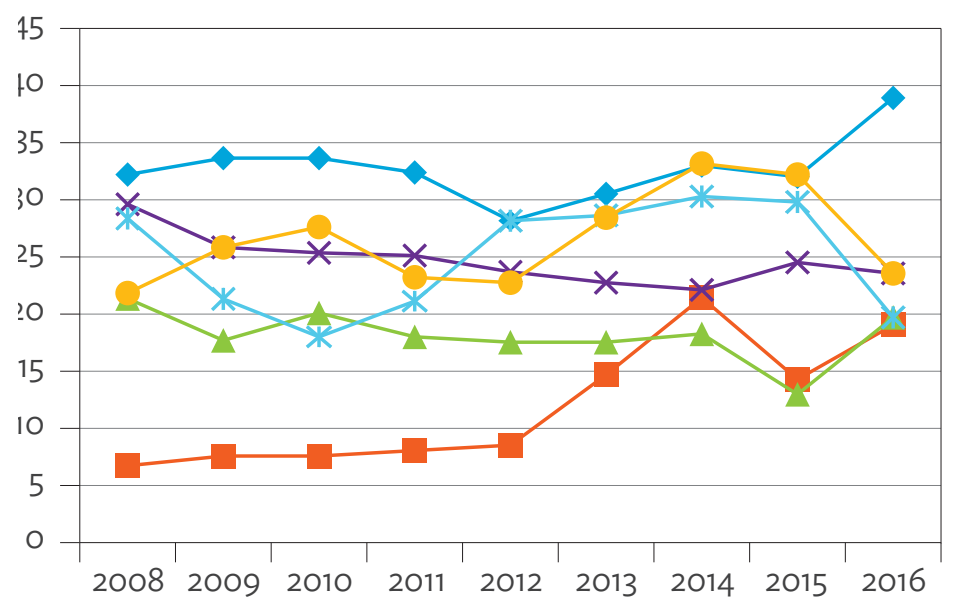

Voice and Accountability

- Political Stability and/or Absence of Violence

- Governance Effectiveness

$\rightarrow$ Regulatory Quality

* Rule of Law

- Control of Corruption

Source: World Bank Institute. http://info.worldbank.org/governance/wgi/index.aspx\#reports.

1 World Bank Institute - Aggregate Governance Indicators. http://info.worldbank.org/governance/wgi/index aspx\#home.

2 The governance dimensions are defined as follows: Voice and Accountability: The extent to which citizens can participate in selecting the government, as well as freedom of expression, association, and a free media. Political Stability and Absence of Violence: Perceptions of the likelihood that the government will be destabilized or overthrown by unconstitutional or violent means, including terrorism. Government Effectiveness: The quality of public services and civil service, and degree of its independence from political pressures, quality of policy formulation and implementation, and credibility of the government's commitment to such policies. Regulatory Quality: The ability of the government to formulate and implement sound policies and regulations that permit and promote private sector development. Rule of Law: The extent to which agents have confidence in and abide by the rules of society, quality of contract enforcement, property rights, likelihood of crime and violence. Control of Corruption: The extent to which public power is exercised for private gain, including petty and grand forms of corruption as well as "capture" of the state by elites and private interests.

3 The WGls show the percentile ranks where, on a continuum from $0 \%$ to $100 \%$, a particular country is placed (i.e., it is a relative ranking). $0 \%$ represents the worst performance among the countries and $100 \%$ the best. 
The ranking for Voice and Accountability, Political Stability and Absence of Violence have improved significantly but the ranking for Control of Corruption and Governance Effectiveness have remained static. Regulatory Quality and Rule of Law have deteriorated substantially. In 2016, the ranking for Voice and Accountability is relatively higher while the rest of the rankings are in the bottom quartile. The Political Stability and Absence of Violence ranking increased considerably since 2013 after the promulgation of the new constitution in 2015. In 2015 it was lower because of demonstrations and a general strike against the constitution and subsequent trade barriers). The political turbulence during the constitutional transition led to confusion and overlaps in mandates, blurred accountability frameworks, legal and institutional complications and capacity gaps during the decade. These are possible reasons for the lower rankings on Regulatory Quality and Rule of Law.

\section{B. Economist Intelligence Unit Index of Democracy}

The index of democracy examines the state of democracy based on five general categories and places countries into one of four groups: full democracies, flawed democracies, hybrid regimes and authoritarian regimes. ${ }^{4}$ The survey consists of 60 questions answered by country experts and draws on public opinion surveys where available. Nepal has been classified as a hybrid regime over the last 10 years. ${ }^{5}$ The $2008-2017$ results are shown in Table A2.1.

Table A2.1: The Economist Intelligence Unit's Index of Democracy

\begin{tabular}{|l|c|c|c|c|c|c|c|}
\hline $\begin{array}{l}\text { (10: Highest, } \\
\text { 0: Lowest) }\end{array}$ & $\begin{array}{c}\text { Overall } \\
\text { Score }\end{array}$ & $\begin{array}{c}\text { Electoral } \\
\text { Process and } \\
\text { Pluralism }\end{array}$ & $\begin{array}{c}\text { Functioning of } \\
\text { Government }\end{array}$ & $\begin{array}{c}\text { Political } \\
\text { Participation }\end{array}$ & $\begin{array}{c}\text { Political } \\
\text { Culture }\end{array}$ & $\begin{array}{c}\text { Civil } \\
\text { Liberties }\end{array}$ & $\begin{array}{c}\text { Rank No. } \\
\text { (167 countries) }\end{array}$ \\
\hline 2008 & 4.05 & 1.33 & 4.29 & 2.78 & 6.25 & 5.59 & 115 \\
2010 & 4.24 & 1.83 & 4.29 & 3.89 & 5.63 & 5.59 & 108 \\
2012 & 4.16 & 2.67 & 4.29 & 3.89 & 4.38 & 5.59 & 111 \\
2014 & 4.77 & 3.92 & 4.29 & 4.44 & 5.63 & 5.59 & 105 \\
2016 & 4.86 & 4.33 & 4.29 & 4.44 & 5.63 & 5.59 & 102 \\
2017 & 5.18 & 4.33 & 5.36 & 5.0 & 5.63 & 5.59 & 94 \\
\hline
\end{tabular}

Source: Economist Intelligence Unit. 2018. Democracy Index 2017: Free Speech Under Attack. http://www.eiu.com/ Handlers/WhitepaperHandler.ashx?fi=Democracy_Index_2017.pdf\&mode=wp\&campaignid=Democracylnd ex2017.

The overall score generally improved over the period (from 4.05 to 5.18). The ranking also improved over 10 years from 115 to 94 . Given the recent elections, the scores for Electoral Process and Pluralism and Political Participation have gone up from 1.33 to 4.33 and from 2.78 to 5.0 respectively. The score for Political Culture has come down and Civil Liberties has remained constant. The score for Functioning of Government has also improved. The 2017 overall score for Nepal is comparable to Liberia, Kenya, Kyrgyz Republic, Madagascar, Uganda and Bhutan. The EIU's Media Freedom Ranking groups Nepal in its Largely Unfree category with a score of 6 and a rank of 71 out of 167 countries.

4 Economist Intelligence Unit Democracy Index: https://www.eiu.com/topic/democracy-index.

5 Hybrid regime (score between 4.0 and 5.9) is defined as: "Elections have substantial irregularities that often prevent them from being both free and fair. Government pressure on opposition parties and candidates may be common. Corruption tends to be widespread and the rule of law is weak. Typically, there is harassment of and pressure on journalists, and the judiciary is not independent." 


\section{Transparency International Corruption Perception Index}

The CPI ranks countries in terms of the degree to which corruption is perceived to exist among public officials and politicians. ${ }^{6}$ It is a composite index that draws on corruption-related data from expert and business surveys. The 2008-2018 results for Nepal are shown in Table A2.2.

Table A2.2: Transparency International Corruption Perception Index

\begin{tabular}{|l|c|c|c|c|c}
\hline Year & No. of Countries & $\begin{array}{c}\text { Ranking } \\
\text { of Nepal }\end{array}$ & CPI Score* & $\begin{array}{c}\text { Confidence } \\
\text { Range }\end{array}$ & Surveys Used \\
\hline 2008 & 180 & 121 & 2.7 & $2.4-3.0$ & 6 \\
2010 & 178 & 146 & 27 & $1.9-2.5$ & 6 \\
2012 & 176 & 139 & 29 & $23-31$ & 5 \\
2014 & 175 & 126 & 27 & $22-35$ & 5 \\
2015 & 168 & 130 & 29 & $21-35$ & 5 \\
2016 & 176 & 131 & 31 & $28-34$ & 6 \\
2017 & 180 & 122 & 31 & - & 6 \\
2018 & 180 & 124 & & - \\
\hline
\end{tabular}

Note: * The CPI score for 2006-2011 was based on the following: 10: highly clean, 0: highly corrupt. From 2012 onward it is 100: highly clean, 0: highly corrupt.

Source: Transparency International Corruption Perception Index. http://wwww.transparency.org/.

The CPI score has improved slightly over the period, but corruption among public officials and politicians continues to be perceived as very high. Nepal's ranking remains static (121 in 2008 and 124 in 2018 out of 180 countries). Nepal's CPI score for 2018 (31) is the same as for Azerbaijan, Kazakhstan, Liberia, Malawi, Mali and Moldova.

\section{Fund for Peace Fragile States Index}

The Fragile States Index ${ }^{7}$ reviews vulnerabilities which contribute to the risk of state fragility. ${ }^{8}$ The index is based on four groups of indicators: Cohesion, Economic, Political and Social and Cross-cutting. Each group has three indicators that are part of a Conflict Assessment System Tool which uses data from three streams: content analyses, quantitative data and qualitative review generated from open-source data, media articles, research reports, and other qualitative data points. The results for Nepal for the period 2008-2018 (with a weight of 1 for each indicator) are shown in Table A2.3.

Overall, Nepal has become moderately more stable during the period (2008-2018), which is seen from the absolute as well as the relative scores. The absolute score for fragility in the last 10 years has come down from 94.2 to 87.9 while its relative ranking (in terms of less fragility, i.e., stability)

6 http://www.transparency.org/.

7 The Fund for Peace Fragile States. https://fragilestatesindex.org/country-data/.

8 The Fragile States Index is produced by The Fund for Peace. It is a critical tool in highlighting not only the normal pressures that all states experience, but also in identifying when those pressures are outweighing a state's capacity to manage those pressures. By highlighting pertinent vulnerabilities which contribute to the risk of state fragility, the index, along with the social science framework and the data analysis tools, makes political risk assessment and early warning of conflict accessible to policy-makers and the public at large. 
has improved from 23 to 39 . The scores for economic and political indicators have generally improved (except for the Human Flight indicator) but the scores for Social and Cross-cutting indicators have deteriorated during the decade (except for External Intervention). The scores for Cohesion indicators have mixed results where the score for Security Apparatus has improved but the scores for Factionalized Elites and Group Grievance have deteriorated. The 2018 total score for Nepal is comparable to that of Zambia, Swaziland, and Timor-Leste.

Table A2.3: Fund for Peace Fragile States Index

\begin{tabular}{l|c|c|c|c|c|c|c|c|}
\hline Cohesion Indicators* & $\mathbf{2 0 0 8}$ & $\mathbf{2 0 1 0}$ & $\mathbf{2 0 1 2}$ & $\mathbf{2 0 1 4}$ & $\mathbf{2 0 1 5}$ & $\mathbf{2 0 1 6}$ & $\mathbf{2 0 1 7}$ & $\mathbf{2 0 1 8}$ \\
\hline Security Apparatus & 8.5 & 7.7 & 7.5 & 7.3 & 7.0 & 6.7 & 6.5 & 6.2 \\
Factionalized Elites & 8.3 & 8.5 & 8.2 & 8.3 & 8.3 & 8.3 & 8.8 & 8.8 \\
Group Grievance & 9.0 & 9.2 & 9.0 & 9.0 & 9.1 & 9.5 & 9.4 & 9.6 \\
Economic Indicators & & & & & & & & \\
Economic Decline & 8.2 & 8.3 & 7.6 & 7.1 & 6.8 & 7.0 & 7.5 & 6.1 \\
Uneven Economic Development & 9.2 & 9.0 & 8.4 & 7.8 & 7.5 & 7.2 & 6.7 & 6.4 \\
Human Flight and Brain Drain & 6.1 & 6.2 & 5.6 & 6.2 & 7.0 & 6.7 & 6.5 & 6.4 \\
Political Indicators & & & & & & & & \\
State Legitimacy & 8.3 & 8.1 & 8.0 & 7.6 & 7.1 & 7.1 & 7.4 & 7.1 \\
Public Services & 7.0 & 7.6 & 7.4 & 7.4 & 7.1 & 7.4 & 7.2 & 6.9 \\
Human Rights and Rule of Law & $\mathbf{8 . 8}$ & $\mathbf{8 . 7}$ & $\mathbf{8 . 2}$ & $\mathbf{7 . 6}$ & $\mathbf{7 . 7}$ & $\mathbf{7 . 4}$ & $\mathbf{7 . 7}$ & $\mathbf{7 . 4}$ \\
Social and Cross-cutting Indicators & & & & & & & & \\
Demographic Pressures & 8.1 & 8.1 & 7.9 & 7.8 & 7.9 & 8.8 & 8.6 & 8.7 \\
Refugees and IDPs & 5.5 & 7.0 & 7.7 & 7.6 & 7.6 & 8.0 & 7.8 & 7.5 \\
External Intervention & 7.2 & 7.0 & 7.4 & 7.3 & 7.4 & 7.1 & 6.9 & 6.8 \\
Total (max. 120 indicating most fragile) & $\mathbf{9 4 . 2}$ & $\mathbf{9 5 . 4}$ & $\mathbf{9 3 . 0}$ & $\mathbf{9 1 . 0}$ & $\mathbf{9 0 . 5}$ & $\mathbf{9 1 . 2}$ & $\mathbf{9 1 . 0}$ & $\mathbf{8 7 . 9}$ \\
Relative Ranking (out of 178 countries) & 23 & 26 & 27 & 31 & 35 & 33 & 33 & 39 \\
\hline
\end{tabular}

Source: The Fund for Peace Fragile States Index https://fragilestatesindex.org/country-data/ Rating scale: 0 least fragile; 10 most fragile.

\section{E. The Heritage Foundation Index of Economic Freedom}

The Index of Economic Freedom ${ }^{9}$ measures economic freedom based on 12 quantitative and qualitative factors, ${ }^{10}$ which are grouped into four broad categories of Rule of Law, Government Size, Regulatory Efficiency and Open Market. The index uses statistics from the World Bank, IMF, and the EIU. The 2008-2018 results for Nepal are shown in Table A2.4.

9 The Heritage Foundation Index of Economic Freedom. https://www.heritage.org/index/.

10 Rule of Law comprises Property Rights: Secured by clear laws that are fully enforced by the state. Freedom from Corruption: Security and certainty in economic relationships; Government Integrity: Fair and equal treatment of all actors in the economic system. Judicial Effectiveness: Efficient and fair judicial systems to ensure that laws are fully respected, with appropriate legal actions taken against violations. Government Size comprises: Government Spending: Expenditures as a percentage of GDP. Fiscal Freedom: Tax burden: Overall tax burden from all forms of taxation as a percentage of GDP. Fiscal Health: Fiscal balance and debt following from the government's budget.

Regulatory Efficiency comprises: Business Freedom: burden of regulation and efficiency of government in the regulatory process. Labor Freedom: Aspects of legal and regulatory framework of labor market. Monetary Freedom: Price stability and price controls. Open Market comprises: Trade Freedom: Absence of tariff and nontariff barriers that affect imports and exports. Investment Freedom: Constraints on the flow of investment capital. Financial Freedom: Banking efficiency as well as independence from government interference in the financial sector. 
Table A2.4: The Heritage Foundation Index of Economic Freedom

\begin{tabular}{|c|c|c|c|c|c|c|c|c|c|}
\hline \multicolumn{2}{|c|}{$\begin{array}{l}\text { Rating scale: } \\
0 \text { (lowest) to } 100 \text { (highest) }\end{array}$} & 2008 & 2010 & 2012 & 2014 & 2015 & 2016 & 2017 & 2018 \\
\hline \multirow[t]{4}{*}{ Rule of law } & Property rights & 30.0 & 35.0 & 30.0 & 30.0 & 30.0 & 30.0 & 37.3 & 37.5 \\
\hline & $\begin{array}{l}\text { Freedom from } \\
\text { corruption }\end{array}$ & 25.0 & 27.0 & 22.0 & 21.3 & 31.0 & 29.0 & - & - \\
\hline & $\begin{array}{l}\text { Government } \\
\text { integrity }\end{array}$ & - & - & - & - & - & - & 26.7 & 24.6 \\
\hline & $\begin{array}{l}\text { Judicial } \\
\text { effectiveness }\end{array}$ & - & - & - & - & - & - & 32.0 & 36.2 \\
\hline \multirow[t]{4}{*}{$\begin{array}{l}\text { Government } \\
\text { size }\end{array}$} & $\begin{array}{l}\text { Government } \\
\text { spending }\end{array}$ & 92.0 & 92.3 & 88.1 & 89.6 & 88.9 & 91.1 & 89.5 & 87.6 \\
\hline & Fiscal freedom & 86.5 & 86.6 & 86.0 & 85.9 & 85.6 & 85.1 & - & - \\
\hline & Tax burden & - & - & - & - & - & - & 84.9 & 84.2 \\
\hline & Fiscal health & - & - & - & - & - & - & 98.4 & 98.5 \\
\hline \multirow{3}{*}{$\begin{array}{l}\text { Regulatory } \\
\text { efficiency }\end{array}$} & Business freedom & 60.0 & 59.4 & 53.6 & 58.5 & 65.7 & 64.9 & 64.6 & 64.6 \\
\hline & Labor freedom & 53.4 & 44.7 & 45.4 & 43.8 & 44.3 & 47.3 & 47.6 & 43.5 \\
\hline & Monetary freedom & 78.5 & 77.8 & 74.9 & 76.3 & 70.5 & 70.8 & 72.2 & 65.8 \\
\hline \multirow[t]{3}{*}{ Open markets } & Trade freedom & 61.4 & 58.8 & 61.5 & 61.0 & 61.8 & 55.6 & 68.1 & 66.6 \\
\hline & $\begin{array}{l}\text { Investment } \\
\text { freedom }\end{array}$ & 30.0 & 15.0 & 10.0 & 5.0 & 5.0 & 5.0 & 10.0 & 10.0 \\
\hline & Financial freedom & 30.0 & 30.0 & 30.0 & 30.0 & 30.0 & 30.0 & 30.0 & 30.0 \\
\hline \multicolumn{2}{|l|}{ Overall score } & 54.7 & 52.7 & 50.2 & 50.1 & 51.3 & 50.9 & 55.1 & 54.1 \\
\hline \multicolumn{2}{|c|}{ Relative global ranking } & $112 / 157$ & $130 / 179$ & $147 / 179$ & $149 / 179$ & $152 / 183$ & $15 / 178$ & $12 / 178$ & $13 / 180$ \\
\hline \multicolumn{2}{|c|}{$\begin{array}{l}\text { Relative ranking in Asia Pacific } \\
\text { region }\end{array}$} & 19 & 28 & 32 & 34 & 34 & 34 & 26 & $32 / 43$ \\
\hline
\end{tabular}

Note: The index ranks countries with scores $100-80$ as Free, 79.9-70 as Most Free, 69.9-60 as Moderately Free, 59.9-50 as Mostly Unfree, and 49.9-0 as Repressed.

Source: The Heritage Foundation Index of Economic Freedom. https://www.heritage.org/index/country/nepal.

Overall economic freedom in Nepal has barely changed from 2008 to 2018, and over the decade between 2008 and 2018 it has been considered Mostly Unfree. The relative global and Asia Pacific rankings have also deteriorated over the decade. Its Rule of Law and Government Size scores have remained largely constant over the decade while its Business Freedom and Trade Freedom indices have improved. However, its Monetary Freedom, Labor Freedom and Investment Freedom indices have declined. The Financial Freedom score has remained the same (30.0) over the period. Nepal's ranking and overall score on the Economic Freedom Index is better than Afghanistan and Maldives and worse than other South Asian countries. The 2018 overall score for Nepal is comparable to that of India, Pakistan, Myanmar, Lao People's Democratic Republic, and Viet Nam. 


\section{F. Bertelsmann Foundation Transformation Index}

The Bertelsmann Transformation Index assesses how countries manage social change toward democracy and a market economy. ${ }^{11}$ It synthesizes findings into: (i) a Status Index, which assesses countries in terms of their path toward constitutional democracy and market economy flanked by sociopolitical safeguards, and (ii) a Governance Index, which assesses the quality of political management. The results are shown in Table A2.5. ${ }^{12}$

The overall trend for Nepal in development toward democracy is positive, with improvements on Political Participation, and Stability of Democratic Institutions. However, the Market Economy Status has worsened slightly. The Governance index slipped from 5.0 to 3.74, and the ranking went down from 61 out of 125 countries in 2008 to 99 out of 129 countries in 2019.

Table A2.5: Bertelsmann Transformation Index 2008-2018

\begin{tabular}{|c|c|c|c|c|c|c|}
\hline $\begin{array}{l}\text { 10: Highest, } \\
\text { 1: Lowest }\end{array}$ & $\begin{array}{c}\text { BTI } 2008 \\
(2007)\end{array}$ & $\begin{array}{l}\text { BTI } 2010 \\
(2009)\end{array}$ & $\begin{array}{c}\text { BTI } 2012 \\
(2011)\end{array}$ & $\begin{array}{c}\text { BTI } 2014 \\
(2013)\end{array}$ & $\begin{array}{l}\text { BTI } 2016 \\
(2015)\end{array}$ & $\begin{array}{c}\text { BTI } 2018 \\
(2017)\end{array}$ \\
\hline Status Index & 4.4 & 4.6 & 4.5 & 4.4 & 4.7 & 4.52 \\
\hline Democracy Status & 3.8 & 5.4 & 5.0 & 4.6 & 5.2 & 4.9 \\
\hline Stateness & 5.0 & 6.3 & 6.0 & 5.5 & 5.5 & 5.0 \\
\hline Political Participation & 3.5 & 6.5 & 6.3 & 5.5 & 6.8 & 6.3 \\
\hline Rule of Law & 4.0 & 5.0 & 4.3 & 4.5 & 4.3 & 4.3 \\
\hline Stability of Democratic Institutions & 2.5 & 5.0 & 4.5 & 3.0 & 5.0 & 5.0 \\
\hline Political and Social Integration & 4.0 & 4.0 & 4.0 & 4.7 & 4.5 & 4.0 \\
\hline Market Economy Status & 5.0 & 3.9 & 3.9 & 4.1 & 4.3 & 4.14 \\
\hline Socioeconomic Level & 3.0 & 2.0 & 2.0 & 2.0 & 2.0 & 2.0 \\
\hline Market Organization & 7.3 & 6.5 & 6.3 & 6.3 & 6.0 & 5.5 \\
\hline Currency and Price Stability & 6.0 & 4.5 & 4.5 & 5.0 & 5.5 & 5.5 \\
\hline Private Property & 7.5 & 5.0 & 5.0 & 5.0 & 5.0 & 5.0 \\
\hline Welfare Regime & 2.5 & 2.5 & 2.5 & 2.5 & 2.5 & 2.5 \\
\hline Economic Performance & 5.0 & 3.0 & 3.0 & 4.0 & 5.0 & 5.0 \\
\hline Sustainability & 3.5 & 3.5 & 4.0 & 4.0 & 4.0 & 3.5 \\
\hline Status Index Ranking & 94 of 125 & 90 of128 & 98 of 128 & 99 of 129 & 90 of 129 & 92 of 129 \\
\hline Governance Index & 5.0 & 4.2 & 3.8 & 4.0 & 4.1 & 3.74 \\
\hline Level of Difficulty & 8.6 & 8.1 & 8.3 & 7.7 & 7.4 & 7.3 \\
\hline Governance Performance & 5.2 & 4.3 & 3.9 & 4.2 & 4.3 & 4.0 \\
\hline Steering Capability & 4.3 & 3.7 & 2.7 & 3.3 & 3.0 & 3.0 \\
\hline Resource Efficiency & 4.0 & 3.3 & 3.0 & 3.0 & 2.7 & 2.7 \\
\hline Consensus Building & 5.4 & 4.0 & 3.6 & 4.8 & 5.2 & 4.6 \\
\hline International Cooperation & 7.0 & 6.3 & 6.3 & 5.7 & 6.3 & 5.7 \\
\hline Governance Index Ranking & 61 of 125 & 93 of 128 & 101 of 128 & 96 of 129 & 95 of 129 & 99 of 129 \\
\hline
\end{tabular}

Source: Bertelsmann Transformation Index https://www.bti-project.org/en/reports/country-reports/detail/itc/NPL/.

11 Bertelsmann Stiftung. Status Index. https://www.bti-project.org/en/data/rankings/status-index/.

$12 \mathrm{BTI}$ scores reflect the status in the previous year, i.e., the BTI 2008 assesses the status as of early 2007. 


\section{G. World Justice Project Rule of Law Index}

The Rule of Law Index assesses rule of law compliance in 113 countries. ${ }^{13}$ There are two data sources: (i) a general population poll conducted in three large cities of each country and, (ii) a qualified respondent questionnaire completed by legal experts. The survey results for Nepal are available only from 2012-2013 when the index was prepared for 97 countries. The factors contributing to the Rule of Law Index are: Constraints on Government Power, Absence of Corruption, Open Government, Fundamental Rights, Order and Security, Regulatory Enforcement, Civil Justice and Criminal Justice. The index scores for Nepal for the period between 2013 to 2018 are shown in Table A2.6. ${ }^{14}$

Table A2.6: World Justice Project Rule of Law Index

\begin{tabular}{|c|c|c|c|c|c|}
\hline $\begin{array}{l}\text { Rating scale: } 0.00 \text { (lowest, i.e., not good) } \\
\text { to } \mathbf{1 . 0 0} \text { (highest, i.e., good) }\end{array}$ & 2013 & 2014 & 2015 & 2016 & 2018 \\
\hline Factor 1: Constraints on Government Powers & 0.51 & 0.56 & 0.62 & 0.63 & 0.61 \\
\hline Factor 2: Absence of Corruption & 0.40 & 0.38 & 0.39 & 0.38 & 0.41 \\
\hline Factor 3: Open Government & 0.38 & 0.44 & 0.56 & 0.54 & 0.52 \\
\hline Factor 4: Fundamental Rights & 0.59 & 0.59 & 0.56 & 0.53 & 0.53 \\
\hline Factor 5: Order and Security & 0.69 & 0.73 & 0.77 & 0.74 & 0.73 \\
\hline Factor 6: Regulatory Enforcement & 0.44 & 0.47 & 0.50 & 0.48 & 0.50 \\
\hline Factor 7: Civil Justice & 0.43 & 0.42 & 0.42 & 0.41 & 0.47 \\
\hline Factor 8: Criminal Justice & 0.54 & 0.43 & 0.42 & 0.44 & 0.43 \\
\hline Overall Score & 0.50 & 0.50 & 0.53 & 0.52 & 0.53 \\
\hline Relative ranking & - & 57 of 99 & 48 of 102 & 63 of 113 & 58 of 113 \\
\hline
\end{tabular}

Source: World Justice Project. Publications: Rule of Law Index Reports. https://worldjusticeproject.org/sites/default/files/ documents/WJP-ROLI-2018-June-Online-Edition_0.pdf.

The overall score for Nepal slightly improved during the five-year survey period but the ranking has not improved even though Nepal is a top performer in South Asia. Although the individual scores for Constraints on Government Powers and Open Government have improved significantly in the last five years, scores for Fundamental Rights and Criminal Justice have declined. The overall score in 2018 is much better than Afghanistan, Bangladesh, and Pakistan, while it is slightly higher than that of India, Indonesia, and Sri Lanka (0.52). Nepal stands with Bulgaria, Macedonia, and Tunisia for 2018.

13 World Justice Project. Rule of Law Index. https://worldjusticeproject.org/our-work/research-and-data/wjp-rule-lawindex-2017-2018.

14 Constraints on Government Powers: Government and officials are subject to and held accountable under the law. Absence of Corruption: Absence of corruption in government. Open Government: engagement, access, participation, and collaboration between government and citizens. Fundamental Rights: Protection of fundamental human rights. Order and Security: How well society assures the security of persons and property. Regulatory Enforcement: The extent to which regulations are fairly and effectively implemented and enforced. Civil Justice: Whether ordinary people can resolve their grievances peacefully and effectively through the civil justice system. Criminal Justice: Whether there is an effective mechanism to redress grievances and bring action against individuals for offenses against society. 


\section{H. Freedom House Freedom in the World Reports}

The Freedom in the World Report measures the degree of democracy and political freedom in 195 countries. ${ }^{15}$ The scores represent the levels of political rights and civil liberties with classifications for Free, Partly Free or Not Free. The 2008-2018 results for Nepal are shown in Table A2.7. ${ }^{16}$

Table A2.7: Freedom of the World Report 2008-2018

\begin{tabular}{|c|c|c|c|c|c|}
\hline $\begin{array}{c}\text { (1: Most free, } \\
\text { 7: Least free) }\end{array}$ & Political Rights & Civil Liberties & Freedom Rating & Freedom Status & Trend \\
\hline 2008 & 5 & 4 & 4.5 & & - \\
\hline 2009 & 4 & 4 & 4 & Partly Free & $\uparrow$ \\
2010 & 4 & 4 & 4 & Partly Free & - \\
2011 & 4 & 4 & 4 & Partly Free & - \\
2012 & 4 & 4 & 4 & Partly Free & - \\
2013 & 4 & 4 & 4 & Partly Free & - \\
2014 & 4 & 4 & 4 & Partly Free & - \\
2015 & 3 & 4 & 3.5 & Partly Free & $\uparrow$ \\
2016 & 3 & 4 & 3.5 & Partly Free & - \\
2017 & 3 & 4 & 3.5 & Partly Free & - \\
\hline 2018 & 3 & 4 & 3.5 & Partly Free & $\uparrow$ \\
\hline
\end{tabular}

Source: Freedom House. Freedom of the World Reports. https://freedomhouse.org/report/freedom-world/2018/nepal.

The freedom rating for Nepal has been Partly Free throughout the period. The ratings for Political Rights improved in 2009, 2015 and 2018 after successive elections for Constituent Assemblies and the legislatures for the three levels of government in the preceding years, but Civil Liberties remained unchanged throughout the decade. Freedom House in 2018 assessed the press in Nepal as Partly Free. Among South Asian countries, Nepal was grouped with Bangladesh, Bhutan, and Afghanistan, which also have a Partly Free press status. Except India (free), other South Asian countries are reported to not have a free press.

\section{Reporters Without Borders World Press Freedom Index}

The World Press Freedom Index ${ }^{17}$ ranks press freedom based on questionnaires sent to partner organizations as well as journalists, researchers, lawyers and human rights activists. ${ }^{18}$ The survey covers direct attacks on journalists and the media as well as other indirect sources of pressure against a free press. The results for Nepal are shown in Table A2.8.

15 Freedom House. Freedom of the World Reports. https://freedomhouse.org/report/freedom-world/freedomworld-2018.

16 The rankings reflect events in the previous year, i.e., 2012 refers to the status in 2011.

17 Reporters Without Borders. World Press Freedom Index. https://rsf.org/en/ranking/.

18 The survey methodology is based on individual perceptions which can result in wide contrasts in a country's ranking from year to year. 
Table A2.8: Reporters Without Borders World Press Freedom Index

\begin{tabular}{l|c|c|c|c|}
$\begin{array}{l}\text { Low grade }=\text { greater } \\
\text { press freedom }\end{array}$ & No. of Countries & Ranking of Nepal & Global Score & $\begin{array}{c}\text { Direction of } \\
\text { Change }\end{array}$ \\
\hline 2008 & 173 & 138 & 43.25 & $\downarrow$ \\
\hline 2010 & 178 & 119 & 36.38 & $\uparrow$ \\
$2011 / 12^{*}$ & 179 & 106 & 38.75 & $\uparrow$ \\
\hline 2014 & 180 & 120 & 36.16 & $\uparrow$ \\
2015 & 180 & 105 & 32.71 & - \\
2016 & 180 & 105 & 32.62 & $\uparrow$ \\
2017 & 180 & 100 & 33.02 & $\downarrow$ \\
\hline 2018 & 180 & 106 & 32.05 & \\
\hline Note: & $*$ The 2011-2012 index was based on a different methodology than was previously applied and allowed for negative \\
& grades and had a wider overall spread of scores (-10 to 142 compared to 115.5 in earlier years). \\
Source: Reporters Without Borders World Press Freedom Index. https://rsf.org/en/ranking. &
\end{tabular}

Press freedom in Nepal has substantially improved during the decade (2008-2018) both in terms of ranking and global score. Its ranking improved from 138 in 2008 (out of 173 countries) to 106 in 2018 (out of 180 countries) and its global score improved from 43.25 to 32.05 during the decade (the lower the ranking and score, the better the press freedom). It still lies in the third quartile. Nepal scored better than all other South Asian countries in 2018 except Bhutan and its score is comparable to those of Montenegro, Guinea, Kuwait, Paraguay, Gabon, and Macedonia.

\section{J. The World Bank Country Policy and Institutional Assessment}

The Country Policy and Institutional Assessment is a diagnostic tool covering 16 areas in four clusters and is intended to capture the quality of a country's policies and institutional arrangements, i.e., the focus is on elements within the country's control rather than outcomes influenced by external elements. ${ }^{19}$ The 2016 results for areas under different clusters and overall IDA Resource Allocation Index (from 2008 to 2016) for Nepal are shown in Table A2.9.

The overall IRAI performance rating for Nepal has changed little (from 3.3 to 3.4) during the period (2008-2016).

19 The World Bank. http://ida.worldbank.org/financing/ida-resource-allocation-index. 
Table A2.9: The World Bank IDA Resource Allocation Index

\begin{tabular}{|c|c|c|c|}
\hline $\begin{array}{l}\text { Rating scale: } \\
1.0 \text { (lowest) to } 6.0 \text { (highest) }\end{array}$ & 2016 & Year & $\begin{array}{l}\text { Overall IDA Resource } \\
\text { Allocation Index (IRAI) }\end{array}$ \\
\hline Cluster A - Economic Management & 3.2 & 2008 & 3.3 \\
\hline Macro-economic Management & 3.0 & 2010 & 3.3 \\
\hline Fiscal Policy & 3.0 & 2012 & 3.3 \\
\hline Debt Policy & 3.5 & 2014 & 3.4 \\
\hline Cluster B - Structural Policies & 3.5 & 2016 & 3.4 \\
\hline Trade & 3.5 & & \\
\hline Financial Sector & 3.5 & & \\
\hline Business Regulatory Environment & 3.5 & & \\
\hline Cluster C - Policies for Social Inclusion/Equity & 3.8 & & \\
\hline Gender Equality & 4.0 & & \\
\hline Equity of Public Resource Use & 4.0 & & \\
\hline Building Human Resources & 4.5 & & \\
\hline Social Protection and Labor & 3.0 & & \\
\hline Policies and Institutions for Environmental Sustainability & 3.5 & & \\
\hline Cluster D - Public Sector Management and Institutions & 3.1 & & \\
\hline Property Rights and Rule Based Governance & 3.0 & & \\
\hline Quality of Budgetary and Financial Management & 3.0 & & \\
\hline Efficiency of Revenue Mobilization & 3.5 & & \\
\hline Quality of Public Administration & 3.0 & & \\
\hline Transparency, Accountability and Corruption in the Public Sector & 3.0 & & \\
\hline IDA Country Performance Rating & 3.1 & & \\
\hline Overall IRAI & 3.4 & & \\
\hline
\end{tabular}

Source: World Bank IDA Resource Allocation Index http://ida.worldbank.org/financing/ida-resource-allocation-index.

\section{K. Asian Development Bank Country Performance Assessment}

The ADB Country Performance Assessment links resource allocation to country performance for the performance-based allocation policy of the current 27 Asian Development Fund countries. ${ }^{20}$ ADB uses the World Bank's country policy and institutional assessment and post-conflict performance indicator questionnaires for the assessment. The 2008-2016 results for Nepal are shown in Table A2.10.

The overall performance rating increased notably from 2008 to 2016 and puts Nepal in sixth position among 27 Asian Development Fund countries. Nepal ranked 7 in 2016 with a score of 4.0 in the categories of overall economic management and structural policies, rank 11 in the category of policies for social inclusion and equity with a score 4.0, rank 6 with a score of 3.9 for policies on public sector management and institutions (governance), rank 5 with a score of 4.5 for portfolio performance, and rank 8 with a score of 4.0 for overall policy performance. Nepal's scores for Property Rights and Rule Based Governance, Quality of Budgetary and Financial Management, Quality of Public Administration, and Transparency, Accountability and Corruption in the public sector remained the same between 2008 and 2016.

20 ADB. https://data.adb.org/dataset/country-performance-assessment-cpa-data. 
Table A2.10: ADB Country Performance Assessment

\begin{tabular}{|c|c|c|c|c|c|c|c|c|c|}
\hline $\begin{array}{l}\text { Rating scale: } 1.0 \text { (lowest) } \\
\text { to } 6.0 \text { (highest) }\end{array}$ & 2008 & 2009 & 2010 & 2011 & 2012 & 2013 & 2014 & 2015 & 2016 \\
\hline Cluster A - Economic Management & 3.8 & 4.3 & 4.0 & 4.2 & 4.3 & 4.0 & 4.0 & 4.0 & 4.0 \\
\hline Monetary and Exchange Rate Policies & 4.0 & 4.5 & 4.0 & 4.5 & 4.5 & 4.5 & 4.5 & 4.5 & 4.5 \\
\hline Fiscal Policy & 4.0 & 4.5 & 4.0 & 4.0 & 4.0 & 3.5 & 3.5 & 3.5 & 3.5 \\
\hline Debt Policy & 3.5 & 4.0 & 4.0 & 4.0 & 4.5 & 4.0 & 4.0 & 4.0 & 4.0 \\
\hline Cluster B - Structural Policies & 3.8 & 4.0 & 4.0 & 4.0 & 4.0 & 4.0 & 4.2 & 4.2 & 4.0 \\
\hline Trade & 4.5 & 4.5 & 4.5 & 4.5 & 4.5 & 4.5 & 4.5 & 4.0 & 4.0 \\
\hline Financial Sector & 3.5 & 4.0 & 4.0 & 4.0 & 4.0 & 4.0 & 4.0 & 4.0 & 4.0 \\
\hline Business Regulatory Environment & 3.5 & 3.5 & 3.5 & 3.5 & 3.5 & 3.5 & 4.0 & 4.0 & 4.0 \\
\hline $\begin{array}{l}\text { Cluster C - Policies for Social Inclusion/ } \\
\text { Equity }\end{array}$ & 3.7 & 4.0 & 4.2 & 4.3 & 4.5 & 4.1 & 4.1 & 4.1 & 4.0 \\
\hline Gender Equality & 4.0 & 4.0 & 4.0 & 4.0 & 4.5 & 4.0 & 4.0 & 4.0 & 4.0 \\
\hline Equity of Public Resource Use & 4.0 & 4.0 & 4.5 & 5.0 & 5.0 & 4.0 & 4.0 & 4.0 & 4.0 \\
\hline Building Human Resources & 3.5 & 4.0 & 4.0 & 4.0 & 4.0 & 4.0 & 4.5 & 4.5 & 4.5 \\
\hline Social Protection and Labor & 3.0 & 3.5 & 4.0 & 4.0 & 3.5 & 4.0 & 4.0 & 4.0 & 4.0 \\
\hline $\begin{array}{l}\text { Policies and Institutions for Environmental } \\
\text { Sustainability }\end{array}$ & 4.0 & 4.5 & 4.5 & 4.5 & 4.5 & 4.5 & 4.0 & 4.0 & 3.5 \\
\hline $\begin{array}{l}\text { Cluster D - Public Sector } \\
\text { Management and Institutions }\end{array}$ & 3.7 & 3.8 & 3.8 & 3.9 & 3.8 & 3.8 & 3.9 & 3.9 & 3.9 \\
\hline Property Rights and Rule Based Governance & 3.5 & 3.5 & 3.0 & 3.0 & 3.0 & 3.0 & 3.5 & 3.5 & 3.5 \\
\hline $\begin{array}{l}\text { Quality of Budgetary and Financial } \\
\text { Management }\end{array}$ & 4.0 & 4.0 & 4.0 & 4.5 & 4.0 & 4.0 & 4.0 & 4.0 & 4.0 \\
\hline Efficiency of Revenue Mobilization & 4.0 & 4.5 & 5.0 & 5.0 & 5.0 & 5.0 & 5.0 & 5.0 & 5.0 \\
\hline Quality of Public Administration & 3.5 & 3.5 & 3.5 & 3.5 & 3.5 & 3.5 & 3.5 & 3.5 & 3.5 \\
\hline $\begin{array}{l}\text { Transparency, Accountability and Corruption } \\
\text { in the Public Sector }\end{array}$ & 3.5 & 3.5 & 3.5 & 3.5 & 3.5 & 3.5 & 3.5 & 3.5 & 3.5 \\
\hline $\begin{array}{l}\text { Portfolio } \\
\text { (proportion of projects at risk from the project } \\
\text { performance reporting system) }\end{array}$ & 3.5 & 3.5 & 3.5 & 4.0 & 3.0 & 3.0 & 4.5 & 4.0 & 4.5 \\
\hline $\begin{array}{l}\text { Composite Country } \\
\text { Performance Rating } \\
\text { (value between 1-36) }\end{array}$ & 13.69 & 14.9 & 14.8 & 16.0 & 14.6 & 14.0 & 16.4 & 15.8 & 16.2 \\
\hline
\end{tabular}

Source: ADB. https://data.adb.org/dataset/country-performance-assessment-cpa-data.

\section{Summary of Findings}

The findings of the international surveys are summarized as follows:

- Nepal is a hybrid regime (EIU Index of Democracy) but because of the successful completion of the peace process, promulgation of a Federal Democratic Constitution by the Constituent Assembly, and peaceful elections for the three levels of government, it is gradually stabilizing politically with better political participation and voice and accountability. Its regulatory quality is still low because of the prolonged transition and government effectiveness has not yet improved.

- Rule of law indicators have remained static with low scores despite improvements in law and order and political stability. The situation of fundamental rights and criminal justice has declined in the last decade. Indices for human rights, political culture and civil liberties have 
declined or remained static over the decade. Press freedom has improved over the decade and the situation in Nepal is better than its South Asian neighbors.

- Government effectiveness and public sector management is overall poor and with little or no changes in the past decade. The indexes for constraints on government power, open government, and regulatory enforcement have improved. The indexes for Property Rights, Quality of Budgetary and Financial Management, Quality of Public Administration, and Transparency and Accountability have remained unchanged over the period 2008-2018.

- The functioning of the market economy and economic management has not improved visibly in the last decade. Economic freedom has slightly improved but economic performance, sustainability, welfare regime, and financial freedom have remained static while indices for market organizations, investment freedom and labor freedom have declined. Business freedom has increased.

- Corruption is perceived to be very high and its indexes (such as the CPI) have remained largely unchanged over the last decade.

Hence, the overall governance situation in Nepal in the past ten years is characterized by relative political stability and electoral participation, but with weak institutional and governance effectiveness and with little improvement in rule of law, economic freedom, combating corruption, and public sector management. 

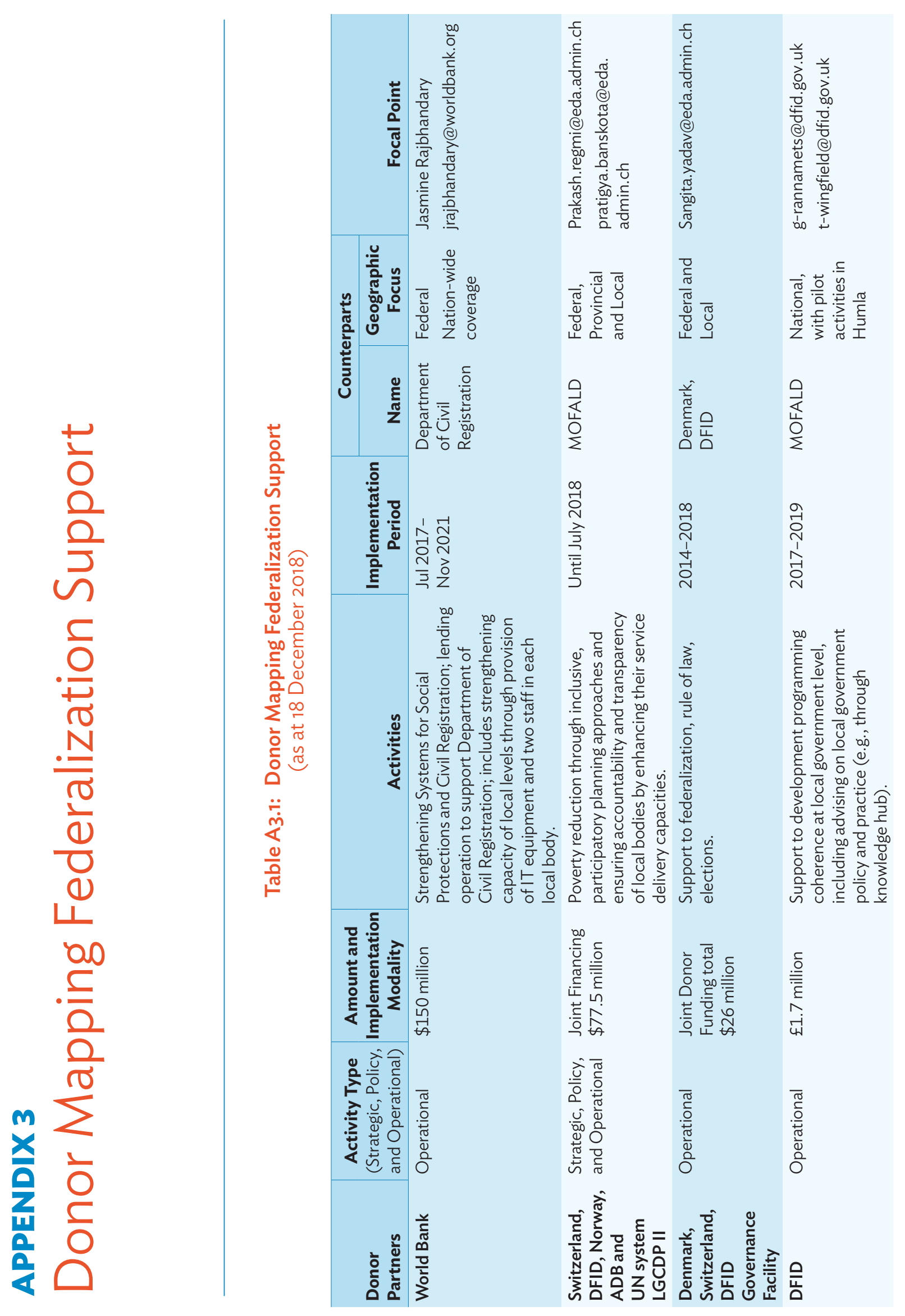


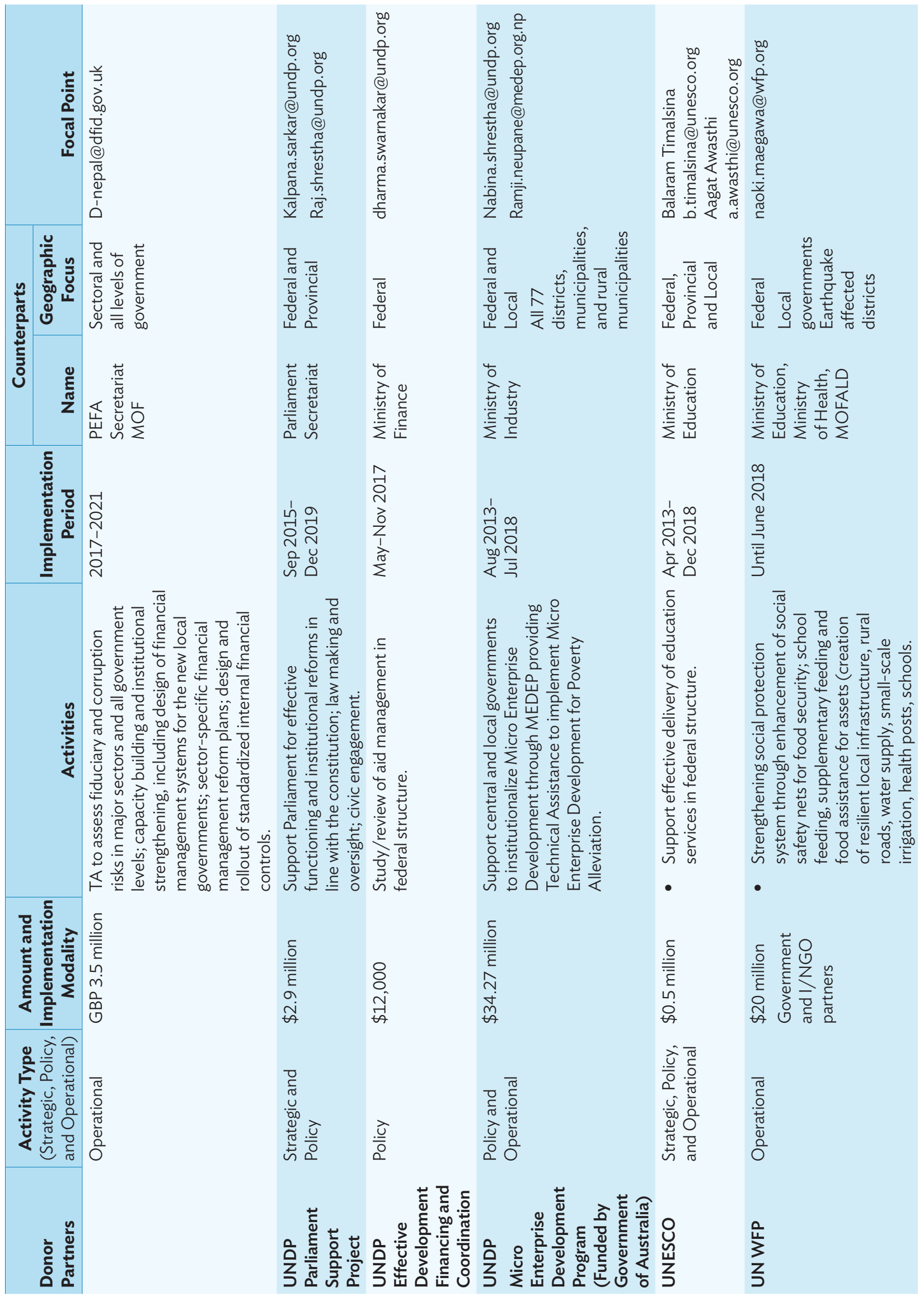




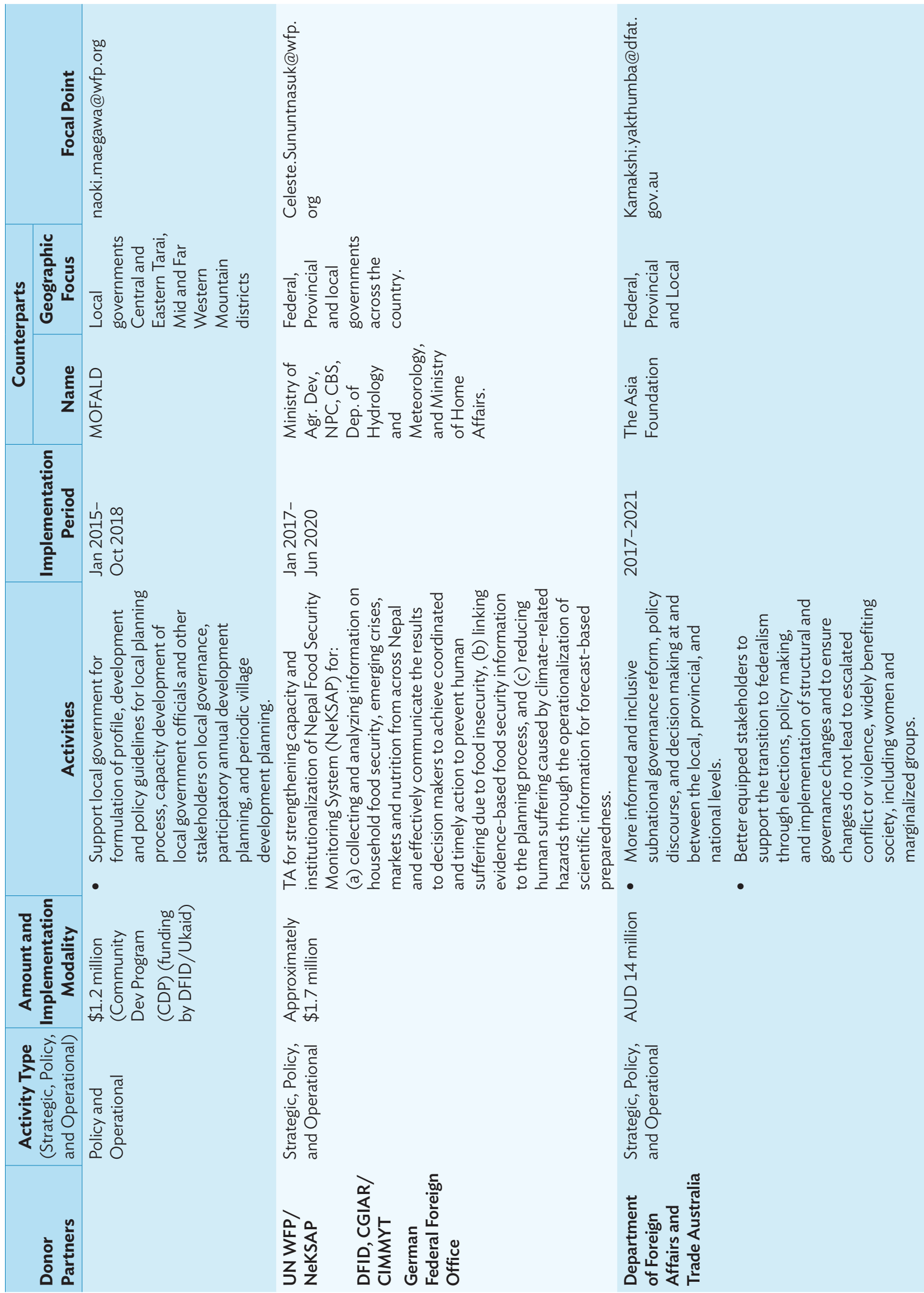




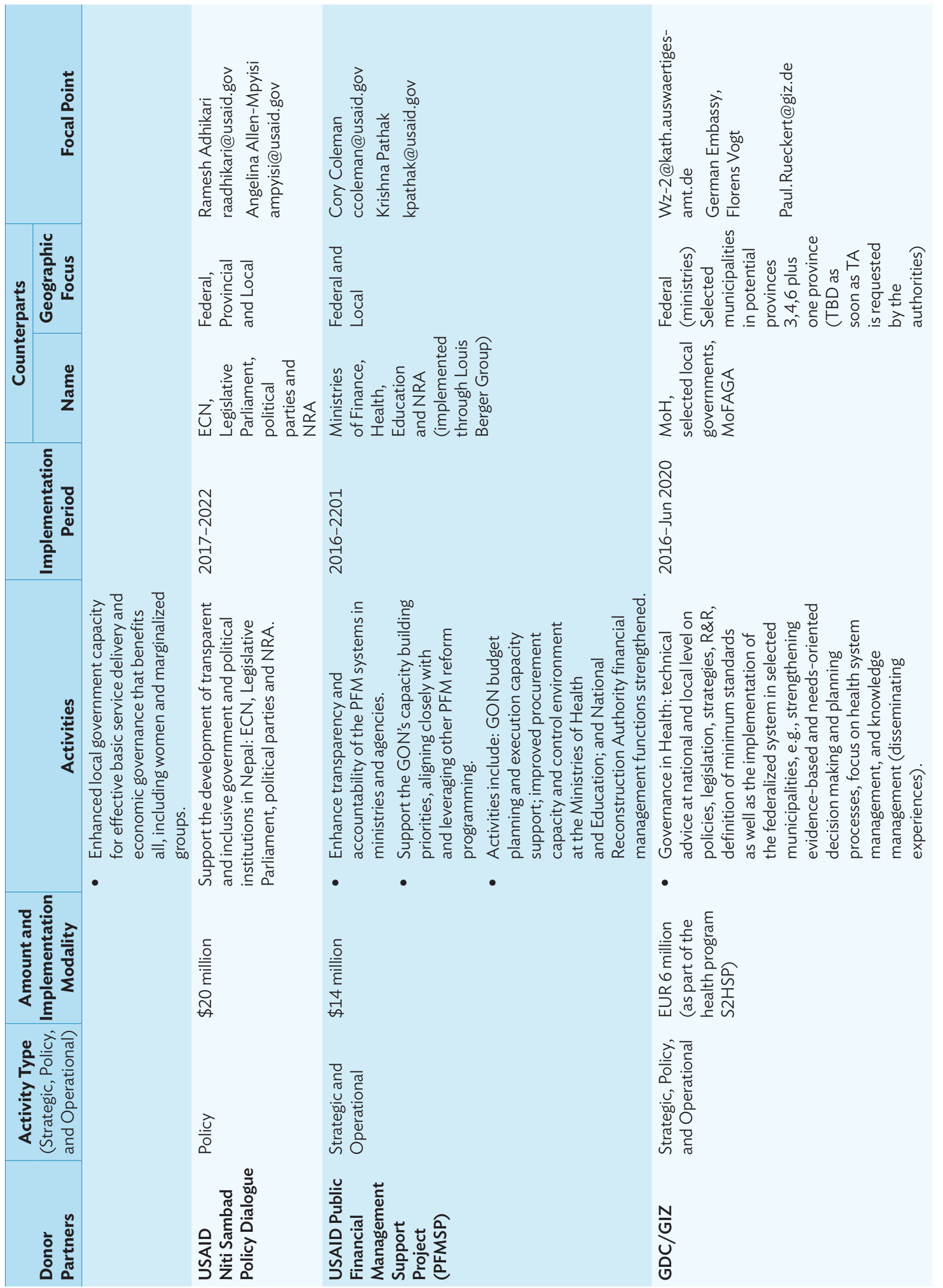




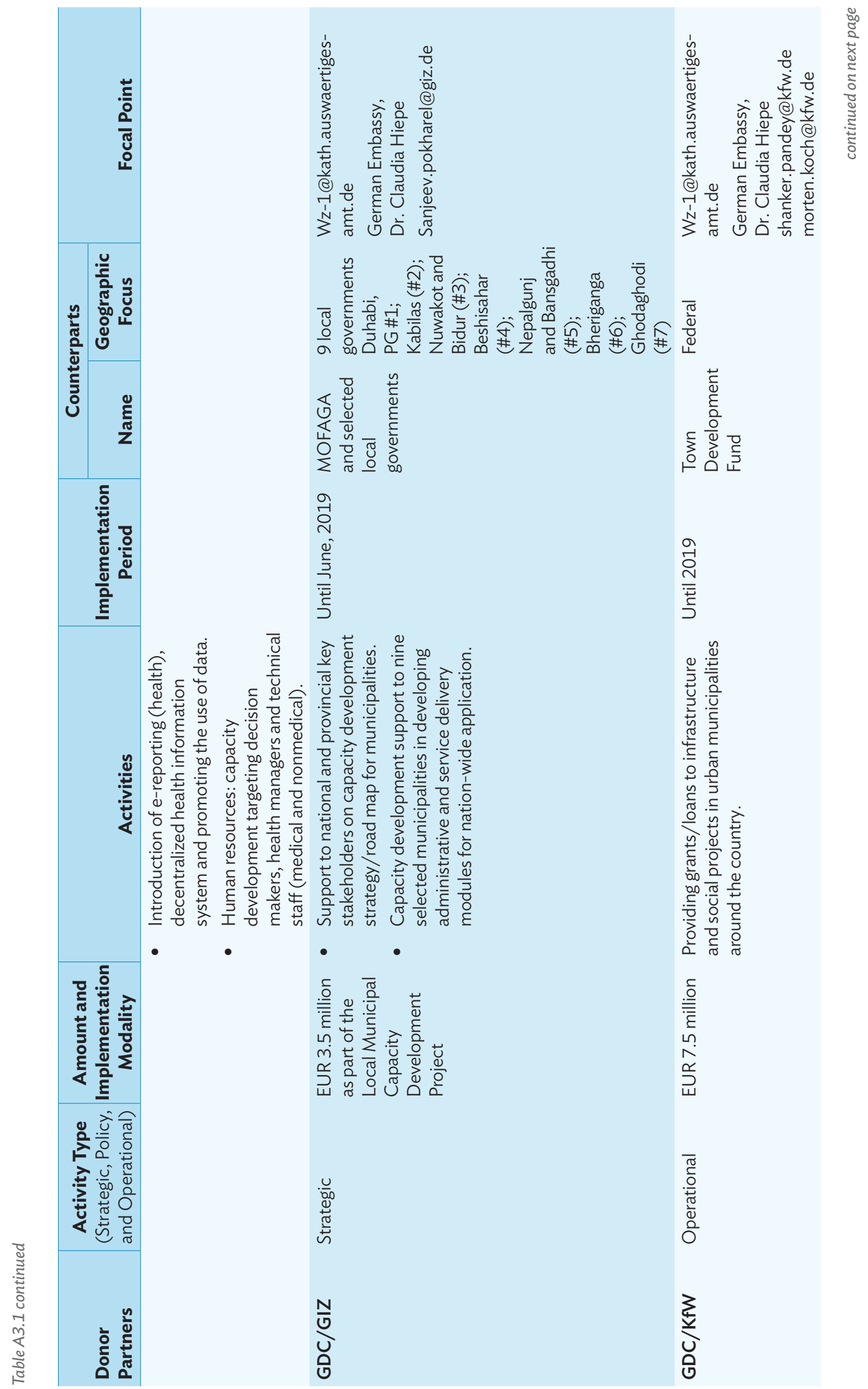




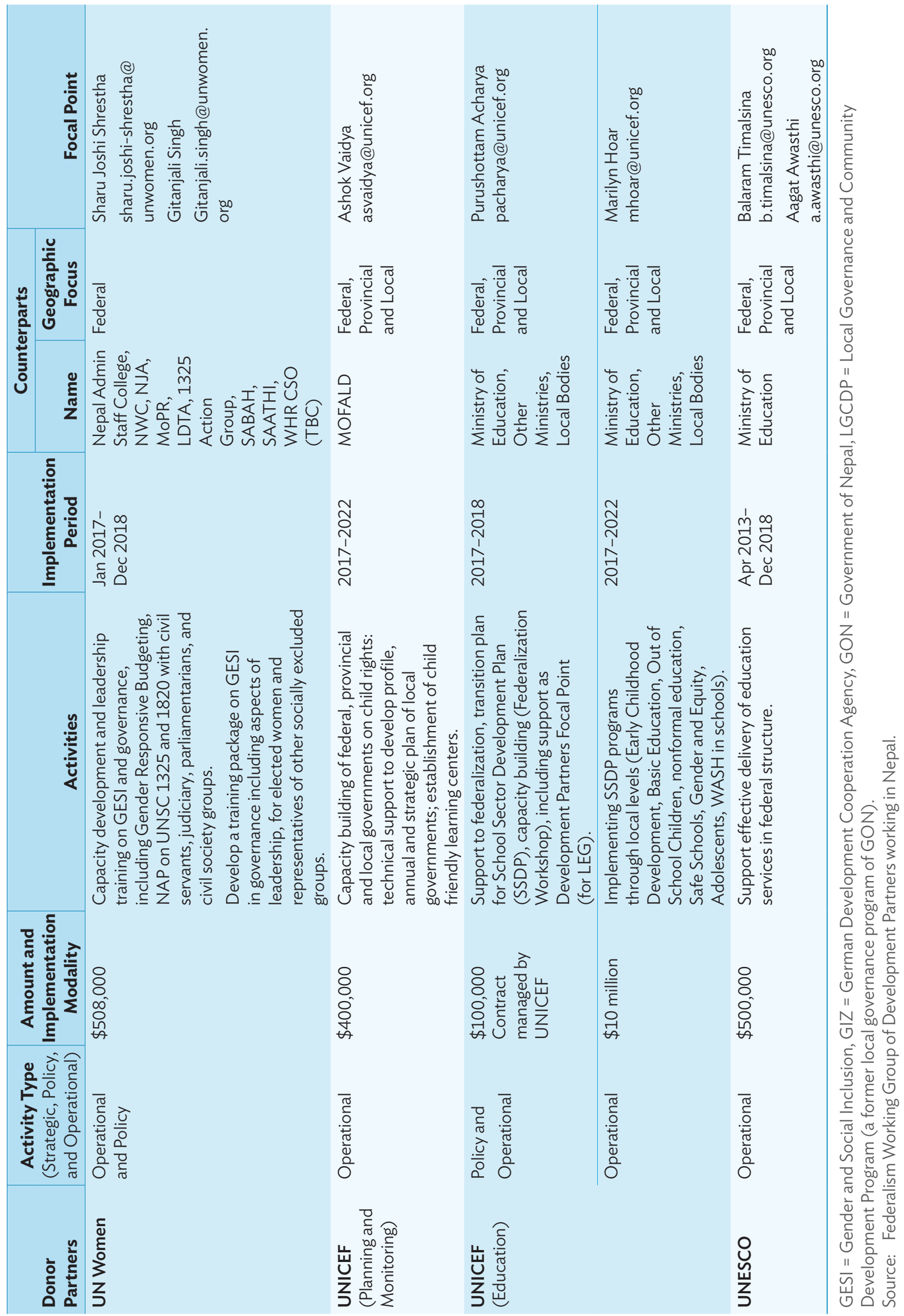




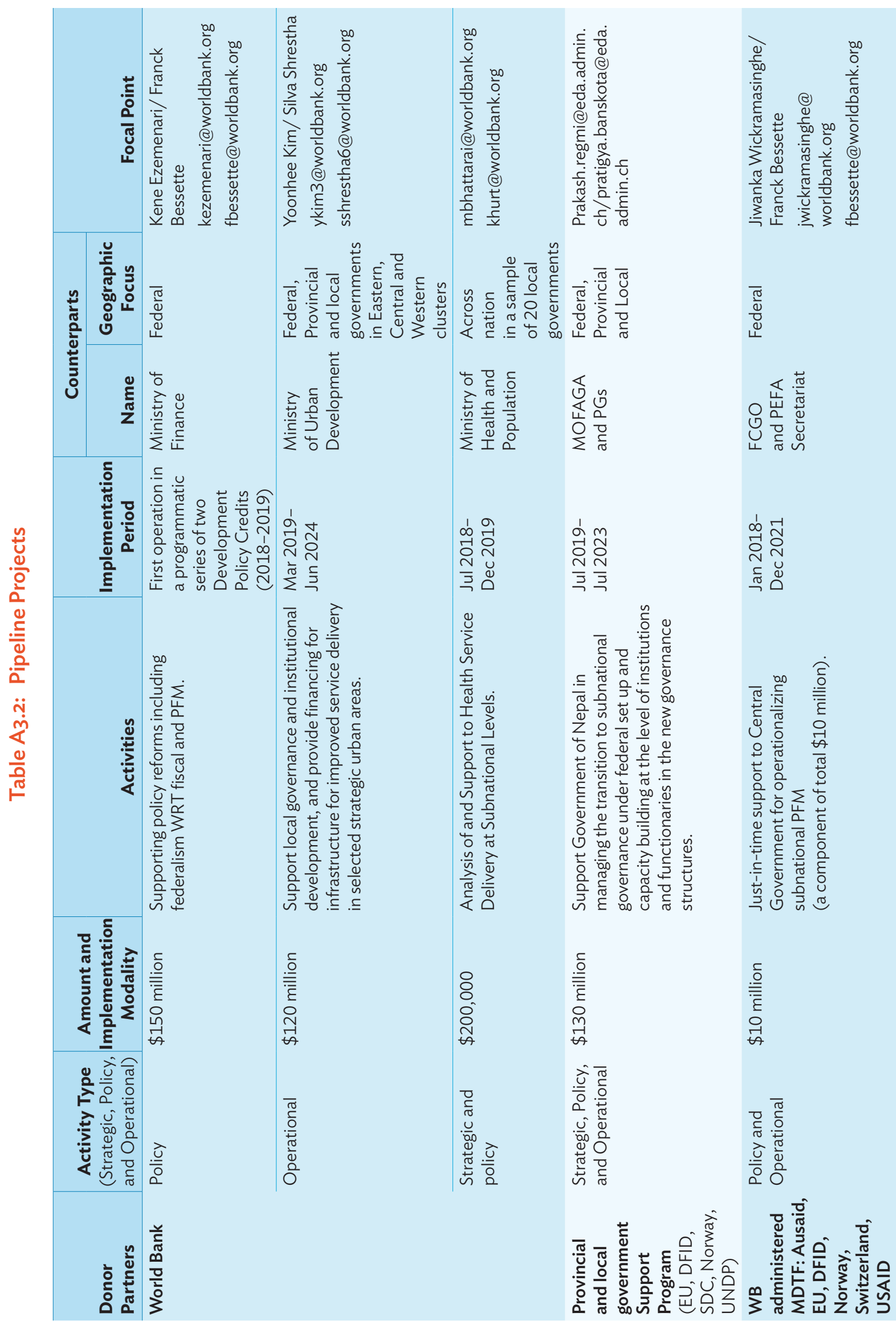




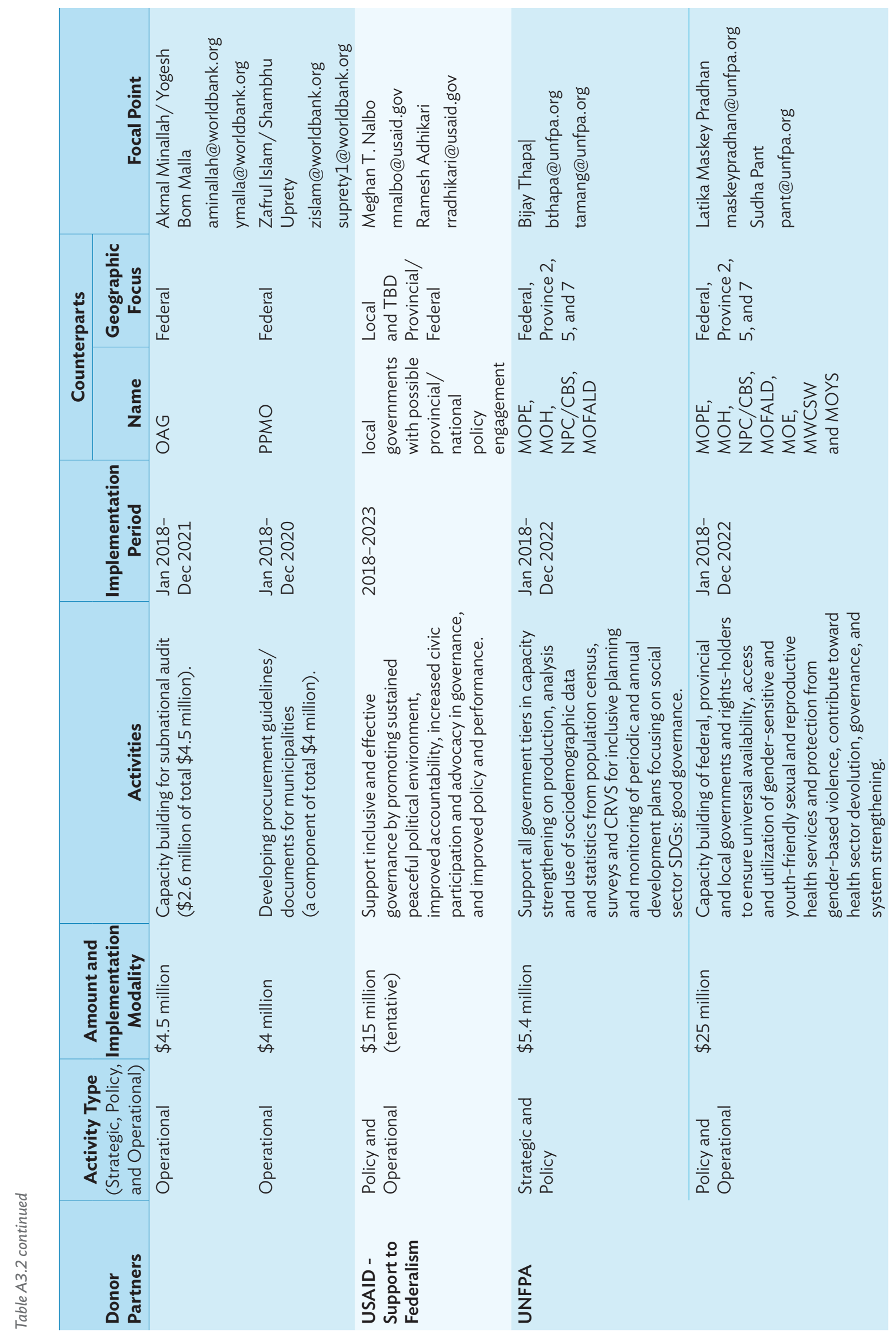




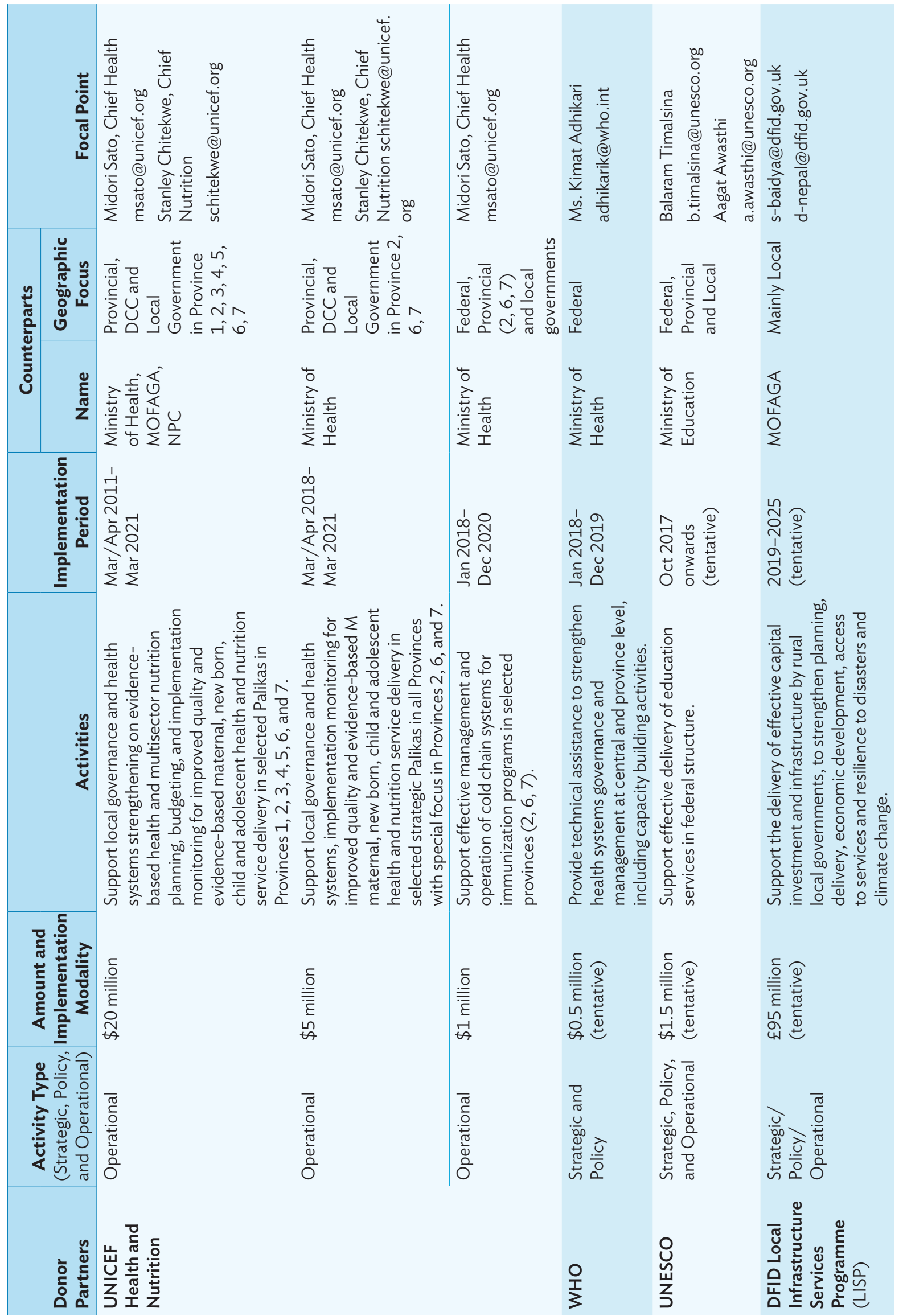




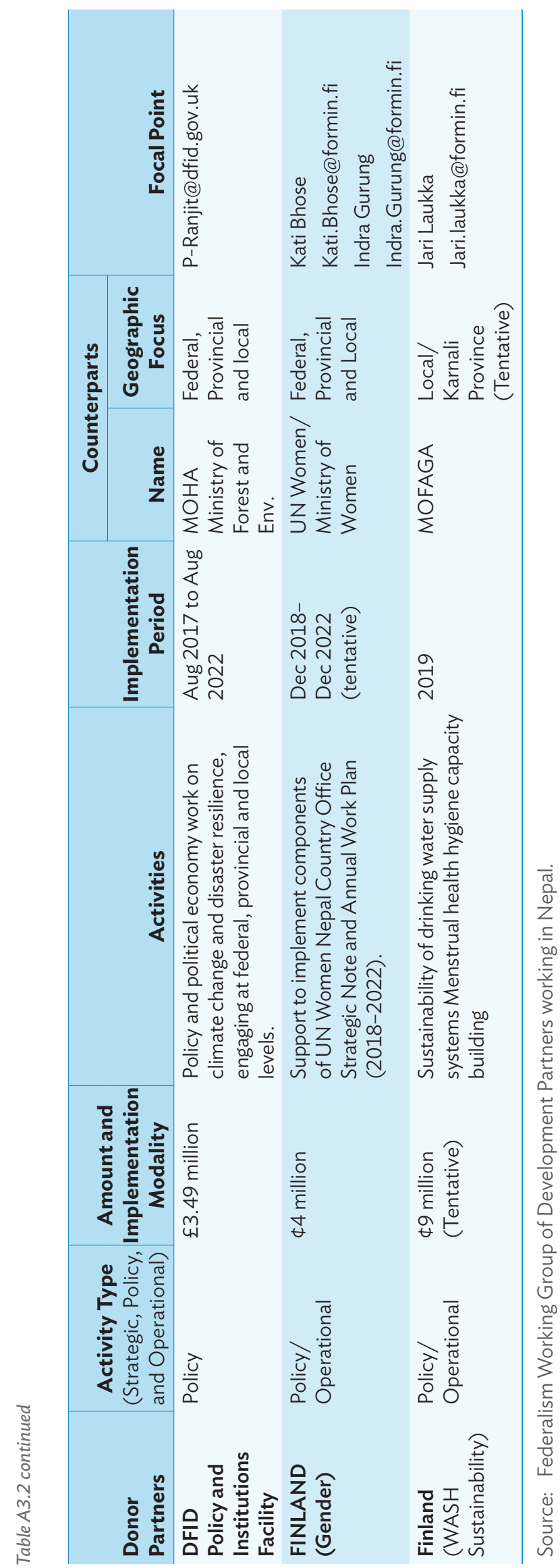



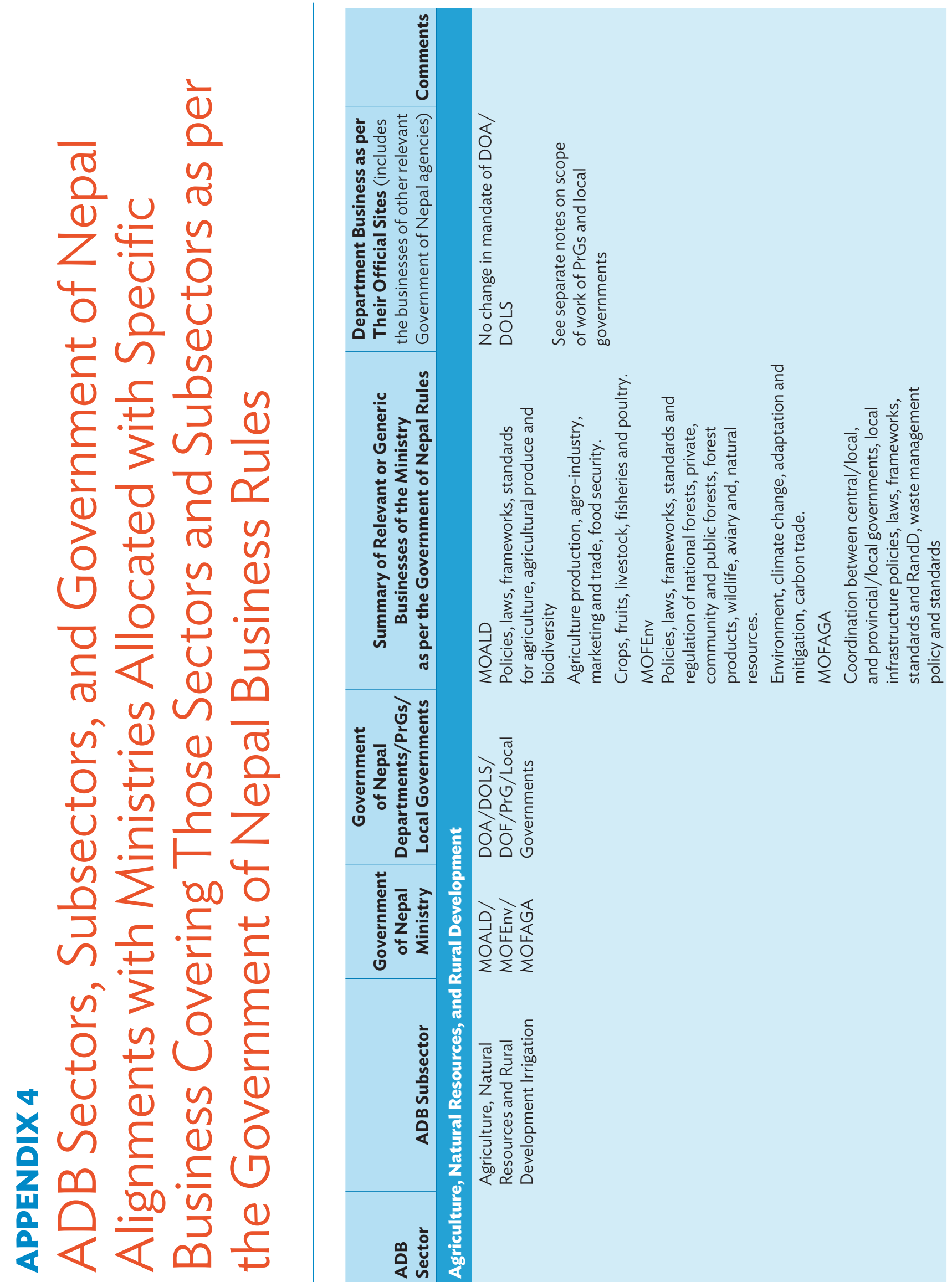

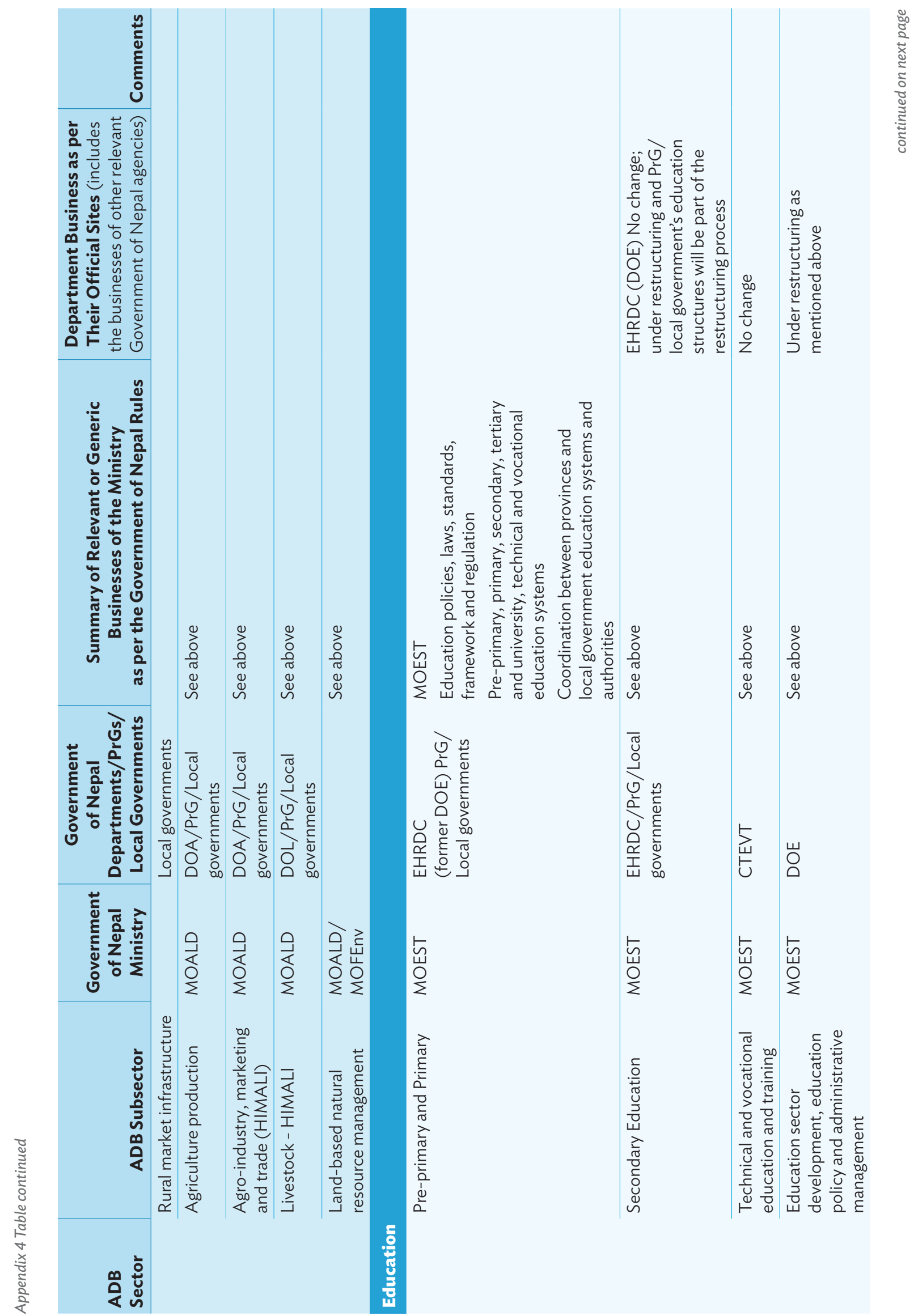

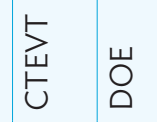

占
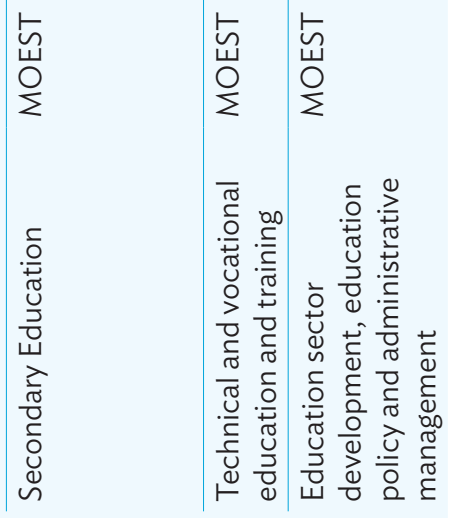


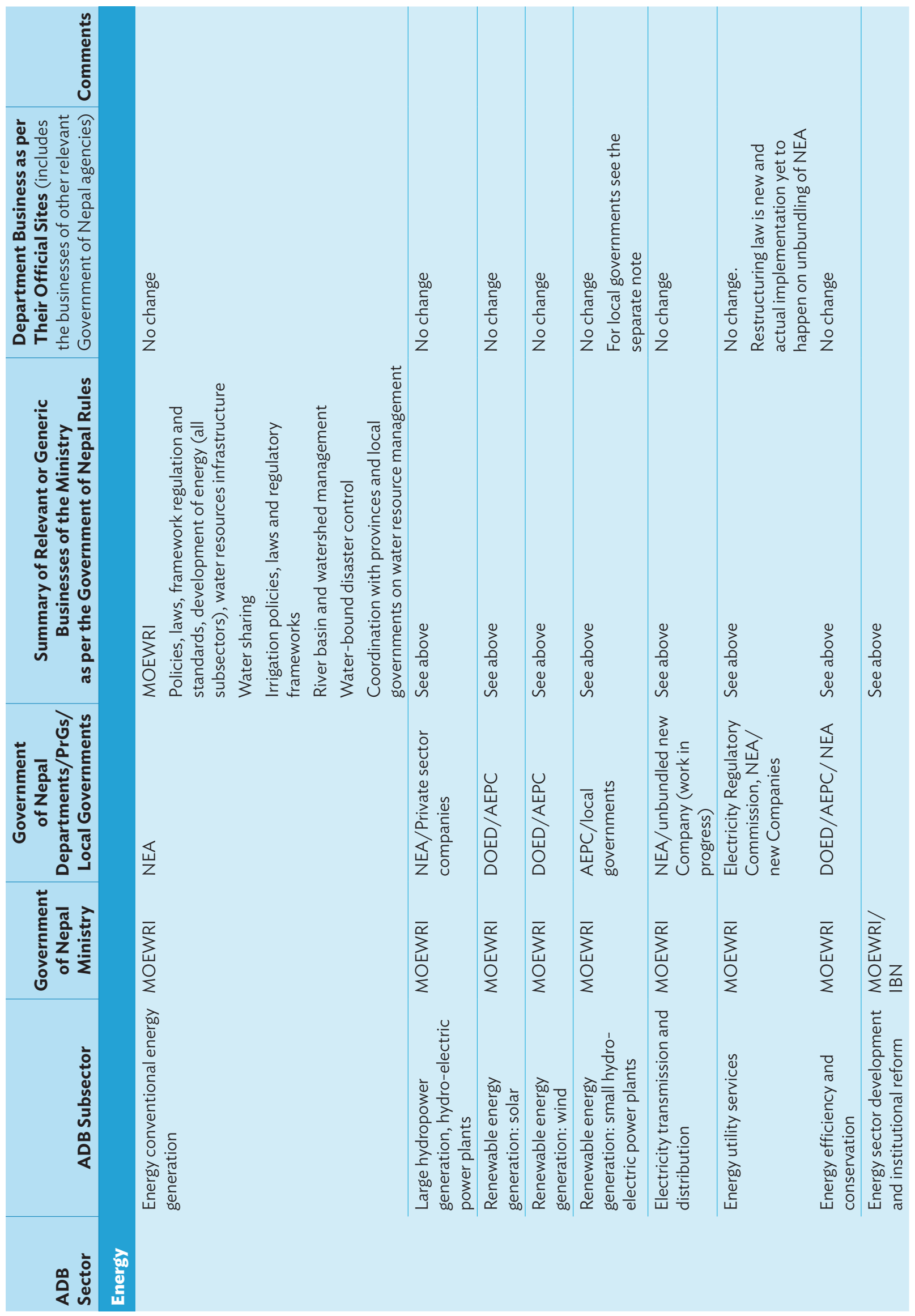




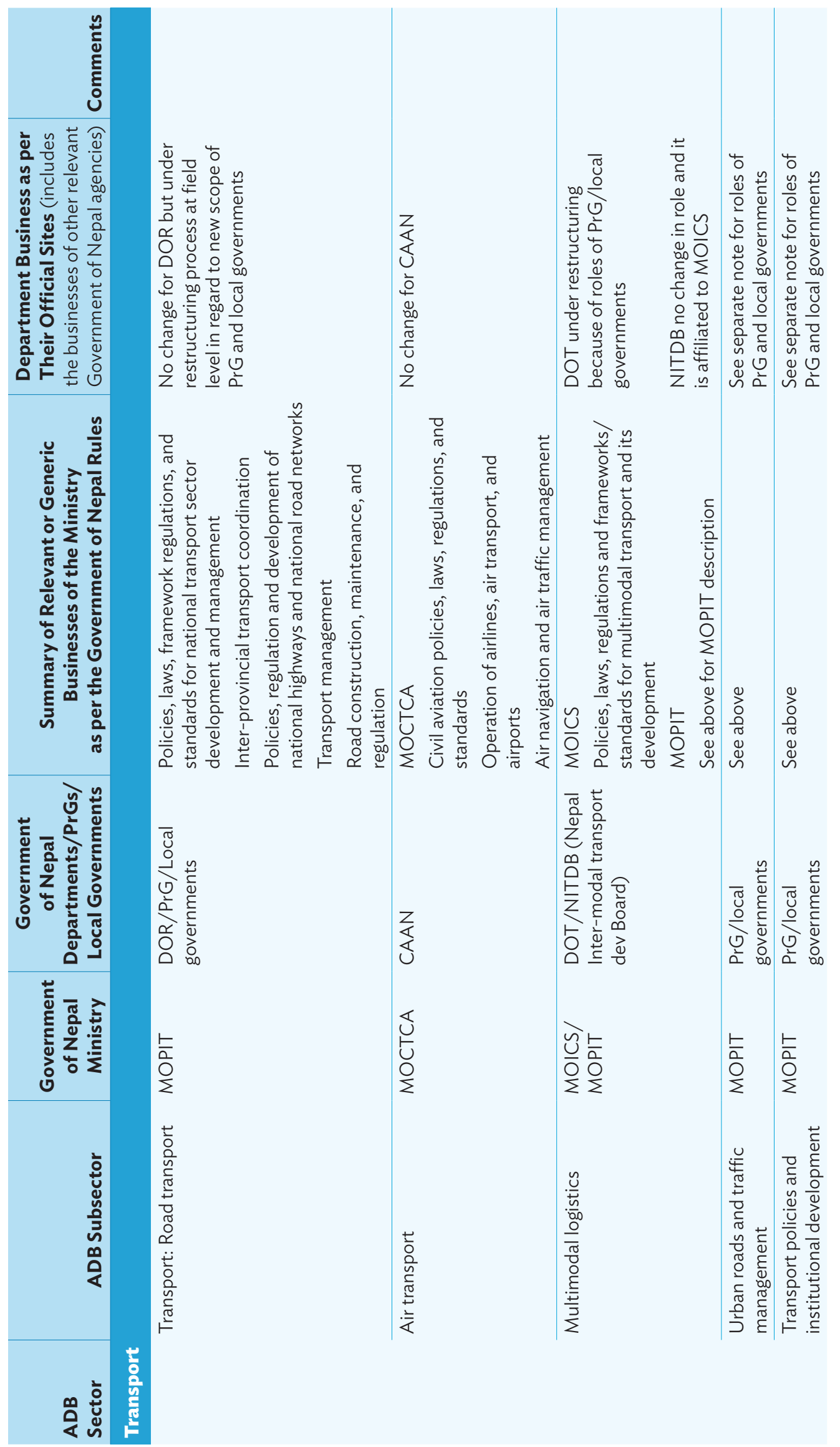




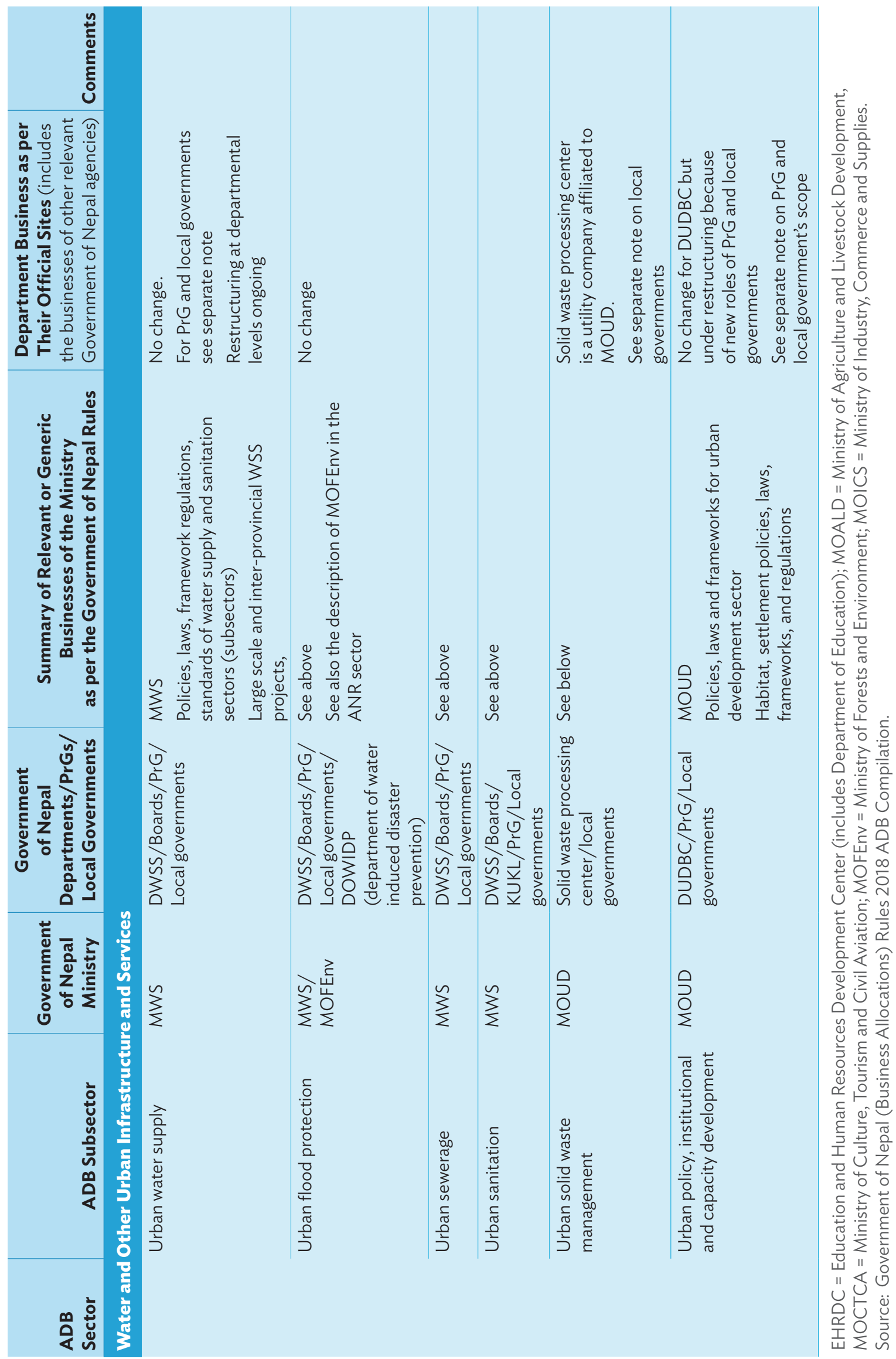




\section{APPENDIX 5 \\ Summary of Rights and Responsibilities of Various Levels of Government}

\begin{tabular}{|c|c|c|c|}
\hline $\begin{array}{l}\text { Exclusive List of } \\
\text { Powers of Central } \\
\text { Government }\end{array}$ & $\begin{array}{c}\text { Exclusive List of } \\
\text { Powers of Provincial } \\
\text { Government }\end{array}$ & $\begin{array}{l}\text { Concurrent List of } \\
\text { Powers of Central } \\
\text { and Provincial } \\
\text { Governments }\end{array}$ & $\begin{array}{l}\text { Concurrent List of } \\
\text { Powers of Central, } \\
\text { Provincial, and Local } \\
\text { Governments }\end{array}$ \\
\hline $\begin{array}{l}\text { Defense, national police, } \\
\text { foreign affairs }\end{array}$ & $\begin{array}{l}\text { Provincial police; law and } \\
\text { order }\end{array}$ & & \\
\hline $\begin{array}{l}\text { Central planning, fiscal } \\
\text { policy, monetary policy and } \\
\text { central bank, banking and } \\
\text { insurance, foreign assistance, } \\
\text { central revenues, central } \\
\text { statistics, cooperatives }\end{array}$ & $\begin{array}{l}\text { Financial institutions, } \\
\text { provincial revenue, foreign } \\
\text { grants with center's consent, } \\
\text { provincial statistics, trust } \\
\text { management }\end{array}$ & $\begin{array}{l}\text { Planning, price control, } \\
\text { monitoring, standards } \\
\text { and quality control, large } \\
\text { infrastructure, insurance }\end{array}$ & $\begin{array}{l}\text { Concurrent revenues like } \\
\text { royalties from natural } \\
\text { resources } \\
\text { Cooperatives }\end{array}$ \\
\hline $\begin{array}{l}\text { Conservation of water } \\
\text { resources and use, } \\
\text { international and inter- } \\
\text { provincial transmission lines, } \\
\text { large electricity }\end{array}$ & $\begin{array}{l}\text { Provincial electricity projects, } \\
\text { water use }\end{array}$ & & Electricity \\
\hline Large irrigation projects & Provincial irrigation projects & & Irrigation \\
\hline $\begin{array}{l}\text { Civil aviation and } \\
\text { international airports, } \\
\text { national railways and } \\
\text { highways }\end{array}$ & $\begin{array}{l}\text { Provincial transport, } \\
\text { provincial highways }\end{array}$ & $\begin{array}{l}\text { Provincial rivers and } \\
\text { waterways }\end{array}$ & \\
\hline \multirow[t]{2}{*}{ International trade } & $\begin{array}{l}\text { Trade within provinces } \\
\text { Industries }\end{array}$ & $\begin{array}{l}\text { Tourism, labor rights, } \\
\text { industrial disputes, supplies, } \\
\text { corporate regulation, } \\
\text { agencies, asset rights }\end{array}$ & \\
\hline & & Industrialization & \\
\hline $\begin{array}{l}\text { Telecommunications, radio, } \\
\text { television, postal services }\end{array}$ & $\begin{array}{l}\text { Communications, radio, FM, } \\
\text { television }\end{array}$ & Communications and media & \\
\hline $\begin{array}{l}\text { Health policy and framework, } \\
\text { large hospitals }\end{array}$ & Health services & $\begin{array}{l}\text { Medicine and drugs, family } \\
\text { planning }\end{array}$ & Health \\
\hline Central universities & $\begin{array}{l}\text { Provincial universities, higher } \\
\text { education }\end{array}$ & $\begin{array}{l}\text { Science and technology, } \\
\text { human resource } \\
\text { development }\end{array}$ & Education, sports \\
\hline $\begin{array}{l}\text { Environment protection, } \\
\text { national parks, carbon } \\
\text { services }\end{array}$ & Provincial forests & Biodiversity & $\begin{array}{l}\text { Forests and wildlife, } \\
\text { biodiversity, mining }\end{array}$ \\
\hline $\begin{array}{l}\text { Land use, habitat } \\
\text { development }\end{array}$ & Land management & $\begin{array}{l}\text { Land use, land policy and } \\
\text { laws }\end{array}$ & Resettlements \\
\hline Poverty alleviation & Poverty alleviation & $\begin{array}{l}\text { Poverty alleviation, } \\
\text { employment, social security }\end{array}$ & $\begin{array}{l}\text { Poverty alleviation, social } \\
\text { security }\end{array}$ \\
\hline
\end{tabular}


Appendix 5 Table continued

\begin{tabular}{|c|c|c|c|}
\hline $\begin{array}{l}\text { Exclusive List of } \\
\text { Powers of Central } \\
\text { Government }\end{array}$ & $\begin{array}{c}\text { Exclusive List of } \\
\text { Powers of Provincial } \\
\text { Government }\end{array}$ & $\begin{array}{l}\text { Concurrent List of } \\
\text { Powers of Central } \\
\text { and Provincial } \\
\text { Governments }\end{array}$ & $\begin{array}{l}\text { Concurrent List of } \\
\text { Powers of Central, } \\
\text { Provincial, and Local } \\
\text { Governments }\end{array}$ \\
\hline $\begin{array}{l}\text { Constitutional bodies and } \\
\text { commissions of national } \\
\text { importance }\end{array}$ & $\begin{array}{l}\text { Provincial Public Service } \\
\text { Commission }\end{array}$ & & \\
\hline \multirow{3}{*}{$\begin{array}{l}\text { Federal civil service, judicial } \\
\text { services }\end{array}$} & Provincial civil service & & \\
\hline & $\begin{array}{l}\text { Agriculture and animal } \\
\text { husbandry }\end{array}$ & & Agriculture \\
\hline & $\begin{array}{l}\text { Provincial water supply } \\
\text { programs }\end{array}$ & Water supply and sanitation & Water supply \\
\hline Residual & & & \\
\hline
\end{tabular}

Source: Constitution of Nepal 2015. 


\section{APPENDIX 6}

\section{Scope of Local Government Responsibilities and ADB Sectors and Subsectors}

\begin{tabular}{|c|c|}
\hline ADB Sectors and Subsectors & Local Government Responsibilities \\
\hline Agriculture and natural resources & $\begin{array}{l}\text { Local agriculture production, agriculture programs, agricultural extension services } \\
\text { and agricultural support including crop production, fisheries, livestock, poultry }\end{array}$ \\
\hline $\begin{array}{l}\text { Agriculture, natural resources, and rural } \\
\text { development and irrigation }\end{array}$ & Rural development, irrigation and other local agriculture input support \\
\hline Rural infrastructure & Rural infrastructure \\
\hline Agriculture production & Local agriculture production \\
\hline Agro-industry, marketing and trade & Local agro-industry, local agriculture marketing \\
\hline Livestock & Local livestock and animal husbandry support \\
\hline $\begin{array}{l}\text { Land-based natural resource } \\
\text { management }\end{array}$ & Local pasture, farming and land use \\
\hline Education & Pre-primary, primary and secondary education \\
\hline Pre-primary and primary & Pre-primary and primary \\
\hline Secondary education & Secondary education \\
\hline TVET & Local TVET policy and operation \\
\hline Energy & Local energy production \\
\hline Renewable energy generation; solar & Alternative energy generation and regulation \\
\hline $\begin{array}{l}\text { Renewable energy generation; small } \\
\text { hydro-electric power plants }\end{array}$ & Less than one megawatt small hydro-electric power plants \\
\hline \multicolumn{2}{|l|}{ Transport } \\
\hline Transport: Roads & Local roads \\
\hline Urban roads and traffic management & Urban and local roads, local transport security \\
\hline Urban public transport & Local urban public transport \\
\hline $\begin{array}{l}\text { Water and other urban } \\
\text { infrastructure and services }\end{array}$ & Local water supply, sanitation and waste management \\
\hline Urban water supply & Local urban water supply \\
\hline Urban sewerage & Local urban sewerage \\
\hline Urban sanitation & Local urban sanitation \\
\hline Urban solid waste management & Local urban solid waste management \\
\hline
\end{tabular}

Source: Local Governments Operations Act 2017. 


\section{APPENDIX 7 \\ ADB Sectors and Assigned Government Ministries in Provinces}

Details are yet to be worked out. There is no Provincial Governments Operation Act like the Local Government Operations Act. The Constitution annexes and the unbundling report as passed by the Cabinet are yet to be detailed.

\begin{tabular}{l|l}
\hline ADB Sectors & \multicolumn{1}{c}{ Provincial Government Responsible Ministries } \\
\hline $\begin{array}{l}\text { Agriculture, Natural Resources, } \\
\text { and Rural Development }\end{array}$ & $\begin{array}{l}\text { Land Management, Agriculture and Cooperatives Ministry/Industry, Tourism, } \\
\text { Education }\end{array}$ \\
$\begin{array}{l}\text { Forests, and Environment Ministry } \\
\text { Energy }\end{array}$ & Social Development Ministry \\
Transport & Physical Infrastructure and Development Ministry \\
$\begin{array}{l}\text { Water and other urban infrastructure } \\
\text { and services }\end{array}$ & Physical Infrastructure and Development Ministry \\
\hline
\end{tabular}

Source: Executive decisions made by the Federal and Provincial Governments of Nepal. 


\section{APPENDIX 8}

\section{Summary of Public Expenditure and Financial Accountability Secretariat 2015 Assessment in Nepal}

According to the 2015 PEFA report, ${ }^{1}$ the status of the six high-level PFM dimensions as at 2014 is briefly described below:

(i) Credibility of budget. The budget, both expenditure and revenue, is credible and credibility has become internalized. One weak spot is the composition of expenditures. Budget variance, although declining with the return of political stability, has resulted from a combination of poor budgets where execution requires re-allocation during the year and some budget indiscipline as evidenced by the number of votes that spend more than the authorized budgets, particularly in public investment by the MOF. The contingency fund is not large because Treasury Single Account and Financial Management Information System payments are timelier and better monitored compared to the last assessment.

(ii) Comprehensiveness and transparency. Budget information has become more transparent after the implementation of Government Finance Statistics classification and the Treasury Single Account. The public's access to fiscal reports has improved. However, fiscal reports are not comprehensive and many autonomous government agencies and donor projects operate outside the Treasury Single Account or Financial management Information System framework. Allocation formulas for unconditional block grants to local bodies are not being followed. The timing of grant releases to local bodies, although trimester-based, is not strictly adhered to. Local bodies and public enterprises regularly submit their financial statements to the center, but their consolidation is delayed. There is no comprehensive assessment of fiscal risks to the government despite major accumulated losses in some public enterprises. Enforcement of financial reporting to autonomous bodies, public enterprises and local bodies can reduce overall fiscal risks.

(iii) Policy-based budgeting. Fiscal prudence at the aggregate fiscal level, facilitated by a rolling medium-term expenditure framework is a strong feature of Nepal's PFM. In the absence of costed sector strategies within an aggregate fiscal framework and lack of capacity for preparing sectoral business plans, there is much room for aligning budgets more closely to development plans. Expansionary investment plans are constrained by weak implementation capacity, especially capital expenditure. Procurement plans are not prepared as part of annual work programs, so the budgets are not realistic. Due to late approval of the budget and cumbersome spending procedures, not much of the annual budget is spent in the first 4 months, and there is always a rush to spend in the last 4 months.

1 Government of Nepal. 2015. Public Expenditure and Financial Accountability (PEFA) Assessment. Kathmandu. 
(iv) Predictability and control in budget execution. The legal and process framework for determining tax liabilities is clear and minimizes discretionary power of tax officers. However, there are issues in the accounting for assessments and collections, and tax arrears have continued to mount each year. There is insufficient attention to clearing old arrears. Parliament approval of the budget, at times, may extend to the end of the first trimester of the fiscal year. As a result, new programs and projects are delayed and subject to political interference outside the formal budget approval process. The payroll is still largely managed manually and is not linked digitally to personnel records. Since 2007, the legal and regulatory framework for procurement has been based on international standards. Most procurement is undertaken through open and competitive bidding, but there is a lack of central data for justifying noncompetitive methods of procurement, and compliance with rules. The developmental impact of spending has been reduced by widespread irregularities and weak enforcement of rules. Commitment control is weak despite the existence of rules and regulations. Internal auditing is beset by conflicts of interest as internal auditors also function, from time to time, as accounts officers. The audit is not focused on internal control systems and their risks but is oriented to identifying transactional irregularities, which reduces its effectiveness.

(v) Accounting, recording and reporting. The Treasury Single Account rollout has strengthened cash-based accounting practices and transparency. Expenditure cash reports are generated, and mid-year reporting is comprehensive, except for the omission of several autonomous government agencies and donor project accounts. Reconciliation of revenue accounts remains an issue. Also, there are technical capacity issues in the recording and analysis of financial statements due to over-stretched accounting personnel and limited refresher training to update people on systemic and accounting standards changes.

(vi) External scrutiny and audit. Weak enforcement of corrective measures against flagged irregularities and lack of progress on recommendations of the OAG have contributed to the weakening of PFM governance. A high-level committee is following up on this. When in session, the Public Accounts Committee has scrutinized issues other than budget execution. This has weakened directives by the legislature to the executive to improve budget execution performance. 


\section{APPENDIX 9}

\section{Summary of Subnational Public Expenditure and Financial Accountability Secretariat 2015 Findings}

\section{A. Reform of the Financial Framework Local Self Governance Act and Local Body Financial Administration Regulation}

The financial framework needs to be overhauled in the following respects:

(i) The Local Bodies Chart of Accounts (CoA) needs to be improved given that the current LBFAR coding is not compliant with Classification of Functions of Government or Government Financial Statistics and that different CoAs are in operation in local bodies. This makes consolidation and analysis of local body data more complicated. A new CoA needs to adequately incorporate accruals accounting, the extension of local body services (e.g., adding redundancy in the coding system) and funding source allowing expenditures to be consolidated but where applicable reported separately to the relevant funding source.

(ii) Provision for budgeting with a medium-term perspective in District Development Committees and municipalities but not in Village Development Committees. This provision should be scaled up in subsequent years focusing initially on the strongest local bodies with significant own-revenue and linked to the annual updating of the periodic plan. Current LBFAR restrictions on the proportion of current expenditures need to be re-examined in light of the need to provide greater recurrent cost to maintain and operate capital projects.

(iii) Local bodies should be encouraged to forecast and manage cash flows of all revenues with the objective of avoiding a year-end spending rush.

(iv) Consideration should be given to promote the use of a single treasury system among local bodies which could involve an extension of the central system or alternatively allowing them to operate a series of linked accounts offered by designated local banks.

(v) LBFAR processes and reporting formats need to be made consistent in view of the gradual computerization of local body accounts and the prospective development and roll out of a new Municipal Administration and Revenue System.

(vi) Incorporation of international and Nepal accounting standards including the concept of additional explanatory notes to the accounts should be included. ${ }^{1}$

1 Government of Nepal. 2016. Sub-National Public Expenditure and Financial Accountability (PEFA) Assessment. Kathmandu. 


\section{B. Compliance with the Financial Framework}

Notwithstanding the deficiencies of the current framework, greater focus is required on compliance to the substance of basic financial control. The minimum conditions and performance measures framework has helped promote greater compliance with the processes of financial control (e.g., preparing and submitting budgets and accounts for audit on time) but the PEFA assessment clearly reveals problems with the quality of data as well as the operation of basic internal controls. The PEFA assessment suggests there needs to be a greater focus on the following core areas: (i) bank reconciliation, (ii) advance account management and reconciliation, (iii) updating of personnel records, and (iv) completion of annual arrears schedules, which should be an integral element of municipal accounting and added as notes to cash-based accounts for District and Village Development Committees.

\section{Developing Financial Management Capacity}

PFM training efforts have to date been largely ad hoc and dependent on development partner funding, with the result that little sustained capacity to build and operate basic systems has been developed. The situation has been aggravated by a lack of understanding of, and therefore commitment to, PFM among senior staff. Frequent turnover of staff at local bodies also undermined sustained capacity building. The lack of commitment is evident in the poor handover of documents resulting in many going missing (especially in Village Development Committees). Corruption cases are also evidence of weak internal control.

While it may not be possible to increase staffing resources, more specific task-based allocation of responsibilities reflected in formal job descriptions could improve focus on problem areas. For example, in many District Development Committees and municipalities, there is no specific separation of revenue and expenditure duties and cash book maintenance and bank reconciliation. Accounts officers who should play a supervising role do not get involved in key tasks such as bank or accounts reconciliations, and in ensuring that accounting systems are adequately backed up. The assessment also revealed numerous problems in the maintenance of documentation, for example, in grant ceiling notifications and payments. The overall maintenance of financial management documentation at local bodies needs to be substantially improved.

\section{High-Level Management of Resource Allocation}

Variations in the level of resources and their timely allocation remain a central problem in improving both the financial management and service effectiveness of local bodies. Variations in the level of resources between years, in-year changes in program priorities and the late notification of (extra) funds undermine proper financial planning and capital project management. The current minimum conditions and performance measures system, while introducing financial incentives for better management, has also introduced instability and unpredictability in grant flows. Changing grant levels in response to deficiencies or strong performance two years previously also undermines incentives to perform while, as noted above, there has been an emphasis on process rather than substance or results. 
Improvements could involve realigning budget timetables with grant notifications to allow for a more accurate estimation of grant resources, and ensuring that incentives are created in the form of additional grants rather than reductions to the base level of grants, which happens for local bodies that fail minimum conditions.

While the higher level of central grants is to be welcomed, local bodies and particularly municipalities need to be given incentives to improve management of local resources like improving collection of property and business taxes. Development allocations for municipalities should include recognition of the need to accelerate preparation of property databases and the valuation and revaluation of properties.

\section{E. Investment in the Development and Use of Information and Communications Technology systems}

District Development Committees (DDC) and municipalities are using computerized systems and the government has the ambition of rolling out Village Development Committee accounting software to most Village Development Committees by FY2016-2017. However, there are several issues with implementation. First, it is clear there may be some design issues with existing software. Second, there is an absence of general training and support for the implementation of the current systems, which means the full potential of these systems may not be realized. The current use of inadequately trained DDC accountants to support the rollout of the VDC accounting system illustrates this problem. Third, there is a tendency to embark on the development of new accounting systems without ensuring that sufficient technical and financial resources have been earmarked for their development with the danger that systems such as the Municipal Accounting System developed with the help of GIZ (2012-2014) are not rolled out as intended and become white elephants. The use of DDC and municipal websites to provide financial information and the e-procurement system also need to be examined.

There is, therefore, a need to develop, implement and adequately resource an ICT strategy for PFM that is not simply an aggregation of individual donor funded projects which exist on their own time scales that may inevitably not allow for proper implementation or rollout. This strategy also needs to take into account the development of central ICT finance systems as well as the likely degree of independence of local bodies from central government under a federal structure. 
Table A9.1: Portfolio of ADB Projects in Nepal

\begin{tabular}{|c|c|c|c|c|}
\hline \multicolumn{2}{|c|}{$\begin{array}{l}\text { Loan No. } \\
\text { Project/Program }\end{array}$} & & $\begin{array}{l}\text { Completion } \\
\text { Date }\end{array}$ & $\begin{array}{c}\text { Net Loan } \\
\text { Amount }\end{array}$ \\
\hline \multicolumn{5}{|c|}{ Agriculture, Natural Resources, and Rural Development } \\
\hline 1. & Loan 3057 & Bagmati River Basin Improvement Project & 29-Feb-20 & 23.565 \\
\hline 2. & Loan 3124 & $\begin{array}{l}\text { Community Managed Irrigated Agriculture } \\
\text { Sector Project AF }\end{array}$ & 31-Jan-22 & 25.148 \\
\hline 3. & Loan 3620 & Rural Connectivity Improvement Project & 31-Jul-23 & 99.440 \\
\hline 4. & Grant 0219 & Community Irrigation Project & 15-Jul-18 & 24.400 \\
\hline 5. & Grant 0233 & $\begin{array}{l}\text { Raising Income of Small and Medium } \\
\text { Farmers Project }\end{array}$ & 30-Jun-19 & 20.100 \\
\hline 6. & Grant 0248 & $\begin{array}{l}\text { High Mountain Agribusiness and Livelihood } \\
\text { Project }\end{array}$ & $16-J u l-18$ & 20.000 \\
\hline 7. & Grant 0299 & $\begin{array}{l}\text { Water Resources Project Preparatory } \\
\text { Facility }\end{array}$ & 30-Jun-19 & 11.000 \\
\hline \multirow[t]{2}{*}{8.} & Grant 0367 & Bagmati River Basin Improvement Project & 29-Feb-20 & 4.500 \\
\hline & & Subtotal & & 228.004 \\
\hline \multicolumn{5}{|c|}{ Education } \\
\hline 9. & Loan 3260 & Earthquake Emergency Assistance Project & 31-Dec-19 & 200.090 \\
\hline 10. & Loan 3452 & $\begin{array}{l}\text { Supporting School Sector Development } \\
\text { Plan }\end{array}$ & 31-May-22 & 118.901 \\
\hline 11. & Loan 3702 & Disaster Resilience of Schools Project & 31-Mar-23 & 148.864 \\
\hline 12. & Grant 0345 & Skills Development Project & 15-Jan-19 & 20.00 \\
\hline \multirow[t]{2}{*}{13.} & Grant 0601 & Disaster Resilience of Schools Project & 31-Mar-23 & 10.000 \\
\hline & & Subtotal & & 497.855 \\
\hline \multicolumn{5}{|c|}{ Energy } \\
\hline 14. & Loan 2808 & $\begin{array}{l}\text { Electricity Transmission Expansion } \\
\text { and Supply Improvement Project }\end{array}$ & 31-Mar-20 & 47.292 \\
\hline 15. & Loan 2990 & Tanahu Hydropower Project & 30-Jun-21 & 108.766 \\
\hline 16. & Loan 2991 & Tanahu Hydropower Project & 30-Jun-21 & 27.145 \\
\hline 17. & Loan 3139 & SASEC Power System Expansion Project & 30-Jun-22 & 162.466 \\
\hline 18. & Loan 3542 & $\begin{array}{l}\text { Power Transmission and Distribution } \\
\text { Efficiency Enhancement Project }\end{array}$ & 30-Jun-22 & 152.007 \\
\hline 19. & Loan 3721 & SASEC Power System Expansion Project AF & 30-Jun-22 & 20.000 \\
\hline 20. & Grant 0270 & $\begin{array}{l}\text { Electricity Transmission Expansion } \\
\text { and Supply Improvement Project }\end{array}$ & 31-Mar-20 & 19.000 \\
\hline \multirow[t]{2}{*}{21.} & Grant 0361 & Project Preparatory Facility for Energy & 30-Jun-20 & 21.000 \\
\hline & & Subtotal & & 557.676 \\
\hline \multicolumn{5}{|c|}{ Finance } \\
\hline \multirow[t]{2}{*}{22.} & Grant 0252 & $\begin{array}{l}\text { Capital Market and Infrastructure Capacity } \\
\text { Support Project }\end{array}$ & 31-Jul-19 & 5.000 \\
\hline & & Subtotal & & 5.000 \\
\hline \multicolumn{5}{|c|}{ Information and Communication Technology } \\
\hline \multirow[t]{2}{*}{23.} & Grant 0106 & ICT Development Project & 31-Dec-18 & 23.500 \\
\hline & & Subtotal & & 23.500 \\
\hline
\end{tabular}


Table A9. 1 continued

\begin{tabular}{|c|c|c|c|c|}
\hline \multicolumn{2}{|c|}{$\begin{array}{l}\text { Loan No. } \\
\text { Project/Program }\end{array}$} & & $\begin{array}{l}\text { Completion } \\
\text { Date }\end{array}$ & $\begin{array}{l}\text { Net Loan } \\
\text { Amount }\end{array}$ \\
\hline \multicolumn{5}{|c|}{ Industry and Trade } \\
\hline \multirow[t]{2}{*}{24.} & Loan 3546 & $\begin{array}{l}\text { SASEC Customs Reform and } \\
\text { Modernization for Trade Facilitation } \\
\text { Program }\end{array}$ & $1-A u g-21$ & 21.404 \\
\hline & & Subtotal & & 21.404 \\
\hline \multicolumn{5}{|c|}{ Transport } \\
\hline 25. & Loan 2579 & $\begin{array}{l}\text { South Asia Tourism Infrastructure } \\
\text { Development Project }\end{array}$ & 15-Jun-19 & 11.517 \\
\hline 26. & Loan 2581 & $\begin{array}{l}\text { Air Transport Capacity Enhancement } \\
\text { Project }\end{array}$ & 31-Dec-18 & 63.626 \\
\hline 27. & Loan 2656 & $\begin{array}{l}\text { Kathmandu Sustainable Urban Transport } \\
\text { Project }\end{array}$ & 31-Dec-17 & 4.451 \\
\hline 28. & Loan 2796 & $\begin{array}{l}\text { Decentralized Rural Infrastructure and } \\
\text { Livelihood Project II }\end{array}$ & 30-Jun-17 & 16.398 \\
\hline 29. & Loan 3012 & SASEC Road Connectivity Project & 30-Jun-19 & 54.530 \\
\hline 30. & Loan 3117 & $\begin{array}{l}\text { South Asia Tourism Infrastructure } \\
\text { Development Project -AF }\end{array}$ & 15-Jun-19 & 27.102 \\
\hline 31. & Loan 3478 & SASEC Roads Improvement Project & $31-J u l-22$ & 186.122 \\
\hline 32. & Loan 3722 & SASEC Highway Improvement Project & $30-J u n-24$ & 180.000 \\
\hline 33. & Grant 0179 & $\begin{array}{l}\text { South Asia Tourism Infrastructure } \\
\text { Development Project }\end{array}$ & 15-Jun-19 & 12.750 \\
\hline 34. & Grant 0181 & Air Transport Capacity Enhancement & 31-Dec-18 & 10.000 \\
\hline 35. & Grant 0212 & $\begin{array}{l}\text { Kathmandu Sustainable Urban Transport } \\
\text { Project }\end{array}$ & 30-Jun-18 & 7.500 \\
\hline 36. & Grant 0227 & Transport Project Preparatory Facility & 31-Dec-18 & 12.000 \\
\hline \multirow[t]{2}{*}{37.} & Grant 0267 & $\begin{array}{l}\text { Decentralized Rural Infrastructure and } \\
\text { Livelihood Project }\end{array}$ & $30-J u n-17$ & 6.670 \\
\hline & & Subtotal & & 592.666 \\
\hline \multicolumn{5}{|c|}{ Water and Other Urban Infrastructure and Services } \\
\hline 38. & Loan1820 & Melamchi Water Supply Project & 30-Jun-19 & 136.103 \\
\hline 39. & Loan 2650 & $\begin{array}{l}\text { Secondary Towns Integrated Urban } \\
\text { Environmental Improvement Project }\end{array}$ & 31-Dec-18 & 58.286 \\
\hline 40. & Loan 2776 & $\begin{array}{l}\text { Kathmandu Valley Water Supply } \\
\text { Improvement Project }\end{array}$ & 30-Jun-19 & 72.407 \\
\hline 41. & Loan 2851 & Integrated Urban Development Project & 31-Dec-19 & 38.663 \\
\hline 42. & Loan 3000 & $\begin{array}{l}\text { Kathmandu Valley Wastewater } \\
\text { Management Project }\end{array}$ & 30-Jun-21 & 74.531 \\
\hline 43. & Loan 3110 & Melamchi Water Supply Project- AF & 30-Jun-19 & 22.580 \\
\hline 44. & Loan 3157 & $\begin{array}{l}\text { Third Small Towns Water Supply and } \\
\text { Sanitation Sector Project }\end{array}$ & 31-Jul-21 & 54.238 \\
\hline 45. & Loan 3255 & $\begin{array}{l}\text { Kathmandu Valley Water Supply } \\
\text { Improvement Project- AF }\end{array}$ & 31-Dec-20 & 91.150 \\
\hline 46. & Loan 3566 & Regional Urban Development & 30-Jun-23 & 150.707 \\
\hline
\end{tabular}




\begin{tabular}{|c|c|c|c|c|}
\hline \multicolumn{2}{|c|}{$\begin{array}{l}\text { Loan No. } \\
\text { Project/Program }\end{array}$} & & $\begin{array}{l}\text { Completion } \\
\text { Date }\end{array}$ & \multirow{2}{*}{$\begin{array}{r}\text { Net Loan } \\
\text { Amount } \\
130.000\end{array}$} \\
\hline 47. & Loan 3711 & $\begin{array}{l}\text { Urban water Supply and Sanitation (Sector) } \\
\text { Project }\end{array}$ & 30-Apr-24 & \\
\hline 48. & Grant 0157 & $\begin{array}{l}\text { Second Small Towns Water Supply } \\
\text { Sanitation Sector Project }\end{array}$ & 31-Dec-17 & 44.600 \\
\hline \multirow[t]{2}{*}{49.} & Grant 0284 & Integrated Urban Development Project & 31-Dec-19 & 10.000 \\
\hline & & Subtotal & & 883.265 \\
\hline \multicolumn{3}{|c|}{ Loan Portfolio Total } & & $2,527.350$ \\
\hline \multicolumn{3}{|c|}{ Grant Portfolio Total } & & 282.020 \\
\hline \multicolumn{3}{|c|}{ Nepal Portfolio Total } & & $2,809.370$ \\
\hline \multicolumn{3}{|c|}{ Nepal Portfolio (w/o Programs) } & & $2,787.966$ \\
\hline
\end{tabular}

Sources: 1. ADB Nepal Resident Mission. Report ID LFIS/ALS760 and GFIS/GRM330.

2. Physically completed.

Run date: 31 December 2018.

Table A9.2: ADB Nepal Resident Mission-Total Loans and Grants in Sectors

\begin{tabular}{|c|c|c|c|c|}
\hline Sectors & No. of Operations & Loan & Grant & Total \\
\hline Agriculture and Natural Resources & 8 & 148.004 & 80 & 228.004 \\
\hline Education & 5 & 467.855 & 30 & 497.855 \\
\hline Energy & 8 & 517.676 & 40 & 557.676 \\
\hline Finance & 1 & & 5.000 & 5.000 \\
\hline Information and Communication Technology & 1 & & 23.500 & 23.500 \\
\hline Industry and Trade & 1 & 21.404 & & 21.404 \\
\hline Transport & 13 & 543.746 & 48.92 & 592.666 \\
\hline Water and Other Urban Infrastructure & 12 & 828.665 & 54.6 & 883.265 \\
\hline Total & & $2,527.350$ & 282.020 & $2,809.370$ \\
\hline$\%$ of total & & $89.96 \%$ & $10.04 \%$ & \\
\hline
\end{tabular}

Source: ADB Nepal Resident Mission. 
Table A9.3: ADB Nepal Resident Mission-List of Active TAs by Sector (as of 31 December 2018)

\begin{tabular}{|c|c|c|c|c|c|c|}
\hline \multicolumn{2}{|c|}{ Ministry/EA } & TA No. & Project Name & $\begin{array}{l}\text { TA } \\
\text { Type }\end{array}$ & $\begin{array}{l}\text { Amount } \\
(\$ \text { million })\end{array}$ & $\begin{array}{l}\text { Revised } \\
\text { Completion }\end{array}$ \\
\hline \multicolumn{7}{|c|}{ Agriculture and Natural Resources } \\
\hline 1. & $\begin{array}{l}\text { Water and Energy } \\
\text { Commission } \\
\text { Secretariat }\end{array}$ & 8500 & Bagmati River Basin Improving Project & PA & 1.000 & 31-Jul-19 \\
\hline 2. & $\mathrm{ADB}$ & 8847 & Enhancing Portfolio Performance & $C D$ & 2.000 & 30-Jun-19 \\
\hline 3. & $\begin{array}{l}\text { Ministry of Urban } \\
\text { Development }\end{array}$ & 9337 & $\begin{array}{l}\text { Bagmati River Basin Improvement - } \\
\text { Additional Financing }\end{array}$ & PP & 0.225 & 31-May-19 \\
\hline 4. & $\mathrm{ADB}$ & 9444 & $\begin{array}{l}\text { Support for Value Chain Development } \\
\text { under the Nepal Agriculture Development } \\
\text { Strategy }\end{array}$ & RD & 0.225 & 30-Jun-19 \\
\hline \multirow[t]{2}{*}{5.} & $A D B$ & 9457 & $\begin{array}{l}\text { Institutional Strengthening of the Nepal } \\
\text { Rural Road Sector for Sustainable } \\
\text { Development }\end{array}$ & $C D$ & 1.000 & 31-Dec-19 \\
\hline & & & Subtotal & & 4.450 & \\
\hline \multicolumn{7}{|c|}{ Education } \\
\hline 6. & $\begin{array}{l}\text { Ministry of } \\
\text { Education }\end{array}$ & 8521 & $\begin{array}{l}\text { Supporting Education and Skills } \\
\text { Development }\end{array}$ & $C D$ & 1.500 & $30-N o v-20$ \\
\hline 7. & $\begin{array}{l}\text { Ministry of } \\
\text { Education }\end{array}$ & 8910 & $\begin{array}{l}\text { Support for Project Implementation of } \\
\text { The Nepal Earthquake Rehabilitation and } \\
\text { Reconstruction Program }\end{array}$ & $C D$ & 3.400 & 31-Dec-19 \\
\hline 8. & $\begin{array}{l}\text { Ministry of } \\
\text { Education }\end{array}$ & 9053 & $\begin{array}{l}\text { Strengthening Higher Engineering } \\
\text { Education }\end{array}$ & PP & 0.800 & 31-Dec-18 \\
\hline \multirow{2}{*}{\multicolumn{2}{|c|}{$\begin{array}{l}\text { 9. Ministry of } \\
\text { Education }\end{array}$}} & 9215 & $\begin{array}{l}\text { Supporting Policies and Implementation in } \\
\text { the School Sector }\end{array}$ & $C D$ & 5.815 & 31-Dec-21 \\
\hline & & & Subtotal & & 11.515 & \\
\hline \multicolumn{7}{|c|}{ Energy } \\
\hline 10. & $\begin{array}{l}\text { Nepal Electricity } \\
\text { Authority }\end{array}$ & 9144 & $\begin{array}{l}\text { Power Transmission and Distribution } \\
\text { Efficiency Enhancement Project }\end{array}$ & PP & 2.000 & 31-Dec-19 \\
\hline \multirow[t]{2}{*}{11.} & $\begin{array}{l}\text { Nepal Electricity } \\
\text { Authority }\end{array}$ & 9334 & $\begin{array}{l}\text { Strengthening the Capacity of Nepal's } \\
\text { Energy Sector to Deliver Gender Equality } \\
\text { and Social Inclusion Results }\end{array}$ & PP & 2.000 & 29-Jun-20 \\
\hline & & & Subtotal & & 4.000 & \\
\hline \multicolumn{7}{|c|}{ Industry and Trade } \\
\hline \multirow[t]{2}{*}{12.} & Ministry of Finance & 9346 & $\begin{array}{l}\text { SASEC Customs Reform and } \\
\text { Modernization for Trade Facilitation }\end{array}$ & $C D$ & 1.000 & 29-Feb-20 \\
\hline & & & Subtotal & & 1.000 & \\
\hline \multicolumn{7}{|c|}{ Public Sector Management } \\
\hline \multirow{2}{*}{\multicolumn{2}{|c|}{ 13. Ministry of Finance }} & 9280 & Hydroelectricity Financing Project & $C D$ & 0.225 & 31-Jan-19 \\
\hline & & & Subtotal & & 0.225 & \\
\hline
\end{tabular}




\begin{tabular}{|c|c|c|c|c|c|}
\hline Ministry/EA & TA No. & Project Name & $\begin{array}{l}\text { TA } \\
\text { Type }\end{array}$ & $\begin{array}{l}\text { Amount } \\
(\$ \text { million })\end{array}$ & $\begin{array}{l}\text { Revised } \\
\text { Completion }\end{array}$ \\
\hline \multicolumn{6}{|l|}{ Health } \\
\hline \multirow[t]{2}{*}{$\begin{array}{l}\text { 14. Nepal Police } \\
\text { Headquarters }\end{array}$} & 8627 & $\begin{array}{l}\text { Supporting Establishing Women and } \\
\text { Children Service Centers }\end{array}$ & $C D$ & 0.500 & 31-Dec-18 \\
\hline & & Subtotal & & 0.500 & \\
\hline \multicolumn{6}{|c|}{ Transport and Communication } \\
\hline \multirow[t]{2}{*}{$\begin{array}{l}\text { 15. Ministry of Physical } \\
\text { Planning and Works }\end{array}$} & 9604 & $\begin{array}{l}\text { Institutional Strengthening of Road Safety } \\
\text { and Gender Equality }\end{array}$ & $C D$ & 0.750 & 31-Jan-22 \\
\hline & & Subtotal & & 0.750 & \\
\hline \multicolumn{6}{|c|}{ Water and Other Urban Infrastructure and Services } \\
\hline $\begin{array}{l}\text { 16. Ministry of Urban } \\
\text { Development }\end{array}$ & 8817 & $\begin{array}{l}\text { Far Western Region Urban Development } \\
\text { Project }\end{array}$ & PP & 1.500 & 30-Jun-19 \\
\hline $\begin{array}{l}\text { 17. Ministry of Urban } \\
\text { Development }\end{array}$ & 9171 & $\begin{array}{l}\text { Second Kathmandu Valley Water Supply } \\
\text { Improvement }\end{array}$ & PP & 1.450 & 28-Feb-20 \\
\hline \multirow[t]{3}{*}{$\begin{array}{l}\text { 18. Ministry of Urban } \\
\text { Development }\end{array}$} & 9384 & $\begin{array}{l}\text { Strengthening Capacity for Urban } \\
\text { Planning, Urban Design and Investment } \\
\text { Planning }\end{array}$ & $C D$ & 1.000 & $31-O c t-20$ \\
\hline & & Subtotal & & 3.950 & \\
\hline & & Nepal Portfolio & & 26.390 & \\
\hline
\end{tabular}

$\mathrm{ADB}=$ Asian Development Bank.

Source: ADB Nepal Resident Mission. 


\section{References}

Anti-Corruption Working Group. 2015. Report of the Technical Mission on Strengthening Cooperation on Anti-Corruption. Kathmandu: Royal Norwegian Embassy.

Alliance for Social Dialogue. 2014. A Description and Analysis of the Budget Formulation and Implementation Process in Nepal. Kathmandu.

Asian Development Bank. 2016. Country Performance Assessment 2016. Manila.

—_. 2016a. Nepal: Country Sector Procurement Assessment Report, 2016. ADB: Kathmandu.

—_. 2017. Country Operations Business Plan: Nepal, 2018-2020. Manila.

- 2018. Development Effectiveness Brief: Nepal-Supporting Inclusive and Accelerated Growth (March 2018). Manila.

_. 2018a. Asian Development Outlook 2018: HowTechnology Affects Jobs. Manila.

—_. Final Report: Technical Assistance to Nepal for Strengthening Subnational Public Management. Unpublished.

—_. 2018c. Nepal: An Update of Country/Sector Procurement Assessment Report, Draft Final Report. June 2018. ADB Nepal Resident Mission: Kathmandu.

Bertelsmann Stiftung. 2018. Bertelsmann Stiftung Index 2018. Nepal. https://www.bti-project.org/en/reports/country-reports/detail/itc/NPL/

Commission for Investigation of Abuse of Authority. 2014. The Institutional Strategy for 2014-2019 of the CIAA. Kathmandu. http://ciaa.gov.np/images/publications/1422355208ciaa_institutional_ strategy_nepali2014_2019.pdf (in Nepali).

Commission for Investigation of Abuse of Authority. 2017. CIAA Twenty-seventh Annual Report, 2017 (22 January, 2017). Kathmandu.

Economist Intelligence Unit. 2017. Democracy Index 2017. London: The Economist.

EU/ALTAIR. 2017. Final Report (December 2017) Support for Coordination and Implementation of the Anti-Corruption Roadmap: Nepal. Kathmandu. 
Freedom House. 2018. Freedom in the World Report 2018. Washington, DC.

https://freedomhouse.org/report/freedom-world/freedom-world-2018

Fund for Peace. 2018. Fragile State Index 2018. Washington, DC. http://fundforpeace.org/fsi/

Government of Nepal, Central Bureau of Statistics. 2018. CBS Data GDP 2018. Kathmandu.

Government of Nepal, Financial Comptroller General Office. 2018. Consolidated Financial Statements FY 2016-2017. Kathmandu.

Government of Nepal, Financial Comptroller General Office. 2018. Standard Procedure for Divisible Fund for Provinces and Local Levels. Kathmandu.

Government of Nepal, Ministry of Federal Affairs and Local Development (now MOFAGA). 2015. Fiduciary Risks Reduction Action Plan (July 2015 to July 2017). Kathmandu.

Government of Nepal, Ministry of Federal Affairs and Local Development (now MOFAGA). 2016. SNG PEFA Report, 2016. Kathmandu.

Government of Nepal, Ministry of Finance. 2015. PEFA Assessment: Nepal PFM Performance Assessment II as of FY 2013-2014 (May 2015). Kathmandu.

Government of Nepal, Ministry of Finance. 2017. Budget Speech of FY 2017-2018. Kathmandu. 2017a. Development Finance Assessment Nepal (November, 2017). Kathmandu.

Government of Nepal, Ministry of Finance. 2018. White Paper on State of Economy by Dr. Y. R. Khatiwada, Finance Minister of Nepal, 30 March 2018. Kathmandu.

- 2018a. Policy Guidelines to Establish Economy and Effectiveness in Public Expenditures (in Nepali, 26 April 2018). Kathmandu.

_. 2018b. Appropriation Bill 2018. Principles and priorities presented at the federal parliament. Kathmandu. 9 May.

Government of Nepal, National Planning Commission. 2018. The Midterm expenditure framework 2075/76-2077/78. Kathmandu.

Government of Nepal, National Planning Commission. 2016. The Fourteenth Plan 2016/17-2018/19 (in Nepali). Kathmandu.

Government of Nepal, National Planning Commission. 2017. National Review of Sustainable Development Goals. Kathmandu.

2017a. Sustainable Development Goals, Status and Roadmap: 2016-2030. Kathmandu. 
Government of Nepal, National Planning Commission/UN. 2018. UN Development Assistance Framework 2018-2022 for Nepal. Kathmandu.

Government of Nepal, National Vigilance Center. 2017. National Vigilance Center Fifteenth Annual Report. Kathmandu.

Government of Nepal, Nepal Law Commission. 2015. Constitution of Nepal, 2015. Kathmandu.

Government of Nepal, Nepal Law Commission. 2017. Inter-Governmental Fiscal Arrangements Act, 2017. Kathmandu.

—. 2017a. Nepal National Resource and Finance Commission Act, 2017. Kathmandu.

_. 2017b. Local Government Operations Act, 2017. Kathmandu.

__. 2017c. Staff Adjustment Act, 2017. Kathmandu.

—. 2017d. Public Procurement Rules (Fourth Amendment), 2017. Kathmandu.

Government of Nepal, Office of the Prime Minister and the Council of Ministers. 2012. Anti-Corruption Strategy and Work Plan to Combat Corruption. Kathmandu.

Government of Nepal, Office of the Prime Minister and the Council of Ministers. 2016. The Unbundling Report, 2016. Kathmandu. www.opmcm.gov.np

Government of Nepal, Office of the Prime Minister and the Council of Ministers. 2018. Government of Nepal (Business Allocation) Rules, 2018. Kathmandu.

Government of Nepal, Public Procurement Monitoring Office. 2013. Nepal Public Procurement Strategy Framework Phase II (2013-2016). Kathmandu.

Government of Nepal, Public Procurement Monitoring Office. 2017. Public Procurement Monitoring Office Annual Report. Kathmandu.

__ 2017a. Public Procurement Monitoring Office Consolidated Report of Public Procurement Monitoring and Complaints. (in Nepali). Kathmandu.

Heritage Foundation. 2018. The Economic Freedom Index 2018. www.heritage.org/index

International Budget Partnership. 2017. Open Budget Survey: Nepal, 2017. https://www.internationalbudget.org/open-budget-survey/results-by-country/countryinfo/?country=np

K. Khadka, B. Koirala, and Y. Timsina. 2015. Anti-Corruption interventions in Nepal (a report prepared for the Anti-Corruption Working Group). Anti-Corruption Working Group and the Norwegian Embassy. Kathmandu. 
Government of Nepal, Office of the Auditor General. 2018. Auditor General's Fifty-fifth Annual Report. April 2018. Kathmandu.

Reporters Without Borders. 2018. World Press Freedom Index 2018. Paris. https://rsf.org/en

Transparency International Nepal. 2014. The National Integrity System Nepal Report, 2014. Kathmandu.

Transparency International. 2017. The Corruption Perception Index Report 2017. Berlin. https://www.transparency.org/country/NPL

World Bank. 2016. IDA Resource Allocation Index 2016. Washington, DC.

2016a. Benchmarking Public Procurement in Assessing Public Procurement Regulatory Systems in 180 Economies. Washington, DC. http://pubdocs.worldbank.org/en/121001523554026106/ BPP17-e-version-Final-compressed-v2.pdf

World Bank. 2017. Nepal Country Economic Memorandum, Climbing Higher: Toward a Middle-Income Nepal, May 2017. Washington, DC.

___ 2017a. Nepal Risk and Resilience Assessment. Washington, DC.

_. 2017b. Nepal Development Update. Washington, DC.

—. 2017c. Worldwide Governance Indicators 2017. Washington, DC. http://info.worldbank.org/governance/wgi/index.aspx\#reports

__ 2017d. Doing Business Report 2018. Washington, DC.

http://www.doingbusiness.org/reports/global-reports/doing-business-2018

—_. 2018. Nepal Systematic Country Diagnostic 2018. Washington, DC.

—. 2018a. South Asia Economic Focus (Spring) 2018. Washington, DC.

__ 2018b. Integrated Public Financial Management Reform Project: Combined Project Information Documents/Integrated Safeguards Datasheet (PID/ISDS). Washington, DC.

_. 2018c. The World Bank Group Country Partnership Strategy for Nepal FY 2019-FY 2023.

Washington, DC. http://documents.worldbank.org/curated/en/394651533563569169/ pdf/129253-WP-P165117-PUBLIC-Two-Pager-CPF-062818.pdf

World Economic Forum. 2018. The Global Competitiveness Index 2017-2018. Geneva. https://www.weforum.org/reports/the-global-competitiveness-report-2017-2018

World Justice Project. 2018. Rule of Law Index 2017-2018. Washington, DC. www.worldjusticeproject.org 


\section{Governance and Institutional Risks and Challenges in Nepal}

With the adoption of its new constitution on 20 September 2015, Nepal became a federal democratic republic. Since then, the country's transition from a unitary system of government to the new federal system has been ongoing and remains a challenging process. This report examines the evolving institutional arrangements, challenges, and governance risks for sectors in which the Asian Development Bank (ADB) operates.

It also identifies potential reform measures that ADB could support to help address these governance risks. The report aims to contribute to the preparation of ADB's 2020-2024 country partnership strategy for Nepal.

\section{About the Asian Development Bank}

ADB is committed to achieving a prosperous, inclusive, resilient, and sustainable Asia and the Pacific, while sustaining its efforts to eradicate extreme poverty. Established in 1966, it is owned by 68 members -49 from the region. Its main instruments for helping its developing member countries are policy dialogue, loans, equity investments, guarantees, grants, and technical assistance. 